\title{
Nitrosonium Reactivity of (NHC)Copper(I) Sulfide Complexes
}

\author{
Abraham J. Jordan ${ }^{\dagger}$, Rebecca K. Walde ${ }^{\dagger}$, Kelly M. Schultz ${ }^{\ddagger}$, John Bacsa ${ }^{\dagger \S}$, Joseph P. Sadighi ${ }^{\dagger *}$ \\ ${ }^{\dagger}$ School of Chemistry and Biochemistry, Georgia Institute of Technology, Atlanta, Georgia 30332-0400, \\ United States \\ ${ }^{\ddagger}$ Department of Chemistry, Murdock Hall, Linfield College, McMinnville, OR 97128, United States \\ $\S$ X-ray Crystallography Center, Department of Chemistry, Emory University, 1515 Dickey Drive, \\ Atlanta, Georgia 30322, United States
}

\section{joseph.sadighi@,chemistry.gatech.edu}

\section{Supporting Information}

\section{Contents}

General Considerations

Spectroscopic Measurements

Elemental Analyses

Experimental Procedures

Deprotonation of $\mathbf{2}$

Conversion of $\mathbf{4}$ to $\mathbf{1}$

Nitrosonium reactivity of 2

Nitrosonium reactivity of $\mathbf{1}$

Nitrosonium reactivity of $\mathbf{4}$

Generation of 7DippCuBF 4

Nitrosonium Reactivity of (7DippCuH $)_{2}$ 
General Considerations. Unless otherwise indicated, manipulations were performed in an MBraun glovebox under an inert atmosphere of nitrogen, or in sealable glassware on a Schlenk line under an atmosphere of argon. Glassware and magnetic stir bars were dried in a ventilated oven at $160^{\circ} \mathrm{C}$ and were allowed to cool under vacuum. Dichloromethane (BDH), hexane (EMD Millipore Omnisolv), tetrahydrofuran (THF, EMD Millipore Omnisolv), toluene (EMD Millipore Omnisolv) were sparged with ultra-high purity argon (NexAir) for 30 minutes prior to first use, dried using an MBraun solvent purification system, transferred to Straus flasks, degassed using three freeze-pump-thaw cycles, and stored under nitrogen or argon. Anhydrous benzene $\left(\mathrm{C}_{6} \mathrm{H}_{6}\right.$, EMD Millipore Drisolv) and, anhydrous pentane (EMD Millipore Drisolv, sealed under a nitrogen atmosphere) were used as received and stored in a glovebox. Tap water was purified in a Barnstead International automated still prior to use.

Benzene- $d_{6}$ (Cambridge Isotope Laboratories) was dried over sodium benzophenone ketyl, vacuum-transferred into oven-dried resealable flasks, and degassed by successive freeze-pumpthaw cycles. Dichloromethane- $d_{2}$ (Cambridge Isotope Laboratories) and acetonitrile- $d_{3}$ (Cambridge Isotope Laboratories) were dried over calcium hydride overnight, vacuum-transferred to an oven-dried resealable Schlenk flask, and degassed by successive freeze-pump-thaw cycles. Chloroform- $d$ (Cambridge Isotope Laboratories) was used as received.

Sodium tert-butoxide (TCI America), copper(I) chloride (Alfa-Aesar), 2,6-diisopropylaniline (Sigma-Aldrich), N,N-diisopropylethylamine (Alfa-Aesar), acetic acid, (Alfa-Aesar), sodium metal (Alfa-Aesar), benzophenone (Alfa-Aesar), calcium hydride (Alfa-Aesar), 1,4dibromobutane (Sigma-Aldrich), triethyl orthoformate (Alfa-Aesar), sodium sulfide (Alfa-Aesar), potassium hydrosulfide (Strem), 2-phenylacetic dithioperoxyanhydride (Matrix), tert-butyl nitrite (Sigma-Aldrich) sodium bis(trimethylsilyl)amide (NaHMDS, Sigma-Aldrich or Strem 
Chemicals), nitrosonium tetrafluoroborate $\left(\mathrm{NO}^{+} \mathrm{BF}_{4}^{-}\right.$, Alfa-Aesar), silver tetrafluoroborate (AlfaAesar), nitrogen (NexAir), and argon (both industrial and ultra-high purity grades, NexAir) were used as received. 7DippCuCl, ${ }^{1} 7 \mathrm{DippCuOtBu}(3),{ }^{1}$ and $(7 \mathrm{DippCuH}){ }_{2}{ }^{1}$ were prepared according to literature protocols and were characterized by ${ }^{1} \mathrm{H}$ NMR spectroscopy.

Spectroscopic Measurements. ${ }^{1} \mathrm{H},{ }^{13} \mathrm{C},{ }^{11} \mathrm{~B}{ }^{19} \mathrm{~F}$, and ${ }^{31} \mathrm{P}$ spectra were obtained using Bruker Avance IIIHD $700 \mathrm{MHz}$, Bruker DSX $400 \mathrm{MHz}$ and Varian Vx $400 \mathrm{MHz}$ spectrometers. ${ }^{1} \mathrm{H}$ and ${ }^{13} \mathrm{C}$ NMR chemical shifts are referenced with respect to solvent signals and reported relative to tetramethylsilane. A capillary insert of $\alpha, \alpha, \alpha$-trifluorotoluene (-63.72 ppm) was used to determine ${ }^{19} \mathrm{~F}$ NMR chemical shifts. ${ }^{31} \mathrm{P}$ NMR chemical shifts were externally referenced to $85 \% \mathrm{H}_{3} \mathrm{PO}_{4}(0.0$ ppm).

Infrared spectra were collected using microcrystalline samples on a Bruker Alpha-P infrared spectrometer equipped with an attenuated total reflection (ATR) attachment. Samples were exposed to air as briefly as possible prior to data collection.

Elemental analyses were performed by Atlantic Microlab, Inc. in Norcross, Georgia. 


\section{Experimental Procedures}

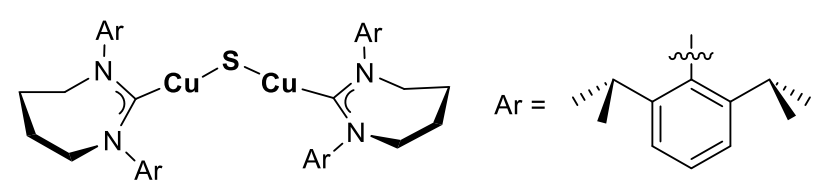

(7DippCu) $)_{2} \mathbf{S}$ (1) 7DippCuCl (0.182 g, $\left.0.352 \mathrm{mmol}\right)$ and sodium sulfide $(0.055 \mathrm{~g}, 0.70 \mathrm{mmol})$ were combined in a $20-\mathrm{mL}$ vial, equipped with a stir bar, before THF $(5 \mathrm{~mL})$ was added. The mixture was allowed to stir for $24 \mathrm{~h}$ before the THF was removed in vacuo. The product was extracted with $\mathrm{C}_{6} \mathrm{H}_{6}(3 \times 3 \mathrm{~mL})$ filtered through Celite and concentrated in vacuo. The resulting yellow solid was washed with $\mathrm{CH}_{3} \mathrm{CN}(2 \times 3 \mathrm{~mL})$, then dried in vacuo to afford the title complex as a yellow solid. $(0.137 \mathrm{~g}, 78 \%$ yield $){ }^{1} \mathrm{H}$ NMR $\left(700 \mathrm{MHz}, \mathrm{C}_{6} \mathrm{D}_{6}\right): \delta(\mathrm{ppm}) 7.15\left(\mathrm{t}, \mathrm{t},{ }^{3} \mathrm{~J}_{\mathrm{HH}}=7.7\right.$ $\mathrm{Hz}, 2 \mathrm{H}$, para-CH), $7.06\left(\mathrm{~d},{ }^{3} J_{\mathrm{HH}}=7.7 \mathrm{~Hz}, 4 \mathrm{H}\right.$, meta- $\left.\mathrm{CH}\right), 3.29(\mathrm{~m}, 4 \mathrm{H}, \mathrm{NCH}), 3.20\left(\mathrm{sept},{ }^{3} J_{\mathrm{HH}}=\right.$ $\left.7.0 \mathrm{~Hz}, 4 \mathrm{H}, \mathrm{CH}\left(\mathrm{CH}_{3}\right)_{2}\right), 1.62\left(\mathrm{~m}, 4 \mathrm{H}, \mathrm{NCH}_{2} \mathrm{CH}_{2}\right), 1.48\left(\mathrm{~d},{ }^{3} J_{\mathrm{HH}}=7.0 \mathrm{~Hz}, 12 \mathrm{H}, \mathrm{CH}_{2}\left(\mathrm{CH}_{3}\right)_{2}\right), 1.27$ $\left(\mathrm{d},{ }^{3} J_{\mathrm{HH}}=7.0 \mathrm{~Hz}, 12 \mathrm{H}, \mathrm{CH}_{2}\left(\mathrm{CH}_{3}\right)_{2}\right) .{ }^{13} \mathrm{C}\left\{{ }^{1} \mathrm{H}\right\} \mathrm{NMR}\left(176 \mathrm{MHz} \mathrm{MHz}, \mathrm{C}_{6} \mathrm{D}_{6}\right): \delta(\mathrm{ppm}) 212.6$ (NCCu), 145.0 (ortho-C), 144.7 (ipso-C), 128.4 (para-C), 124.6 (meta-C), $54.1\left(\mathrm{NCH}_{2}\right), 28.9$ $\left(\mathrm{CH}\left(\mathrm{CH}_{3}\right)_{2}\right), 25.9\left(\mathrm{CH}\left(\mathrm{CH}_{3}\right)_{2}\right), 25.1\left(\mathrm{NCH}_{2} \mathrm{CH}_{2}\right), 24.9\left(\mathrm{CH}\left(\mathrm{CH}_{3}\right)_{2}\right)$. IR: $v\left(\mathrm{~cm}^{-1}\right)$ 2958, 2927, 2864 , 1486, 1427, 1384, 1361, 1320, 1299, 1286, 1177, 1105, 1057, 999, 938, 799, 721, 550, 446, 434.

Note: We have been unable to obtain satisfactory elemental analysis for $\mathbf{1}$. The complex is extremely air-and moisture-sensitive. While NMR-silent impurities cannot be ruled out, we believe the ${ }^{1} \mathrm{H}$ and ${ }^{13} \mathrm{C}$ NMR spectra provided reflect the purity of the sample. After addition of 1,4dichlorobutane to a benzene solution of $\mathbf{1}$ and concentration in vacuo, to remove tetrahydrothiophene, and excess 1,4-dichlorobutane, the more stable 7DippCuCl complex was isolated without further purification and the elemental analysis was obtained (see p. S16). We reasoned that only a sufficiently pure sample of $\mathbf{1}$ would give rise to analytically pure 7DippCuCl. 


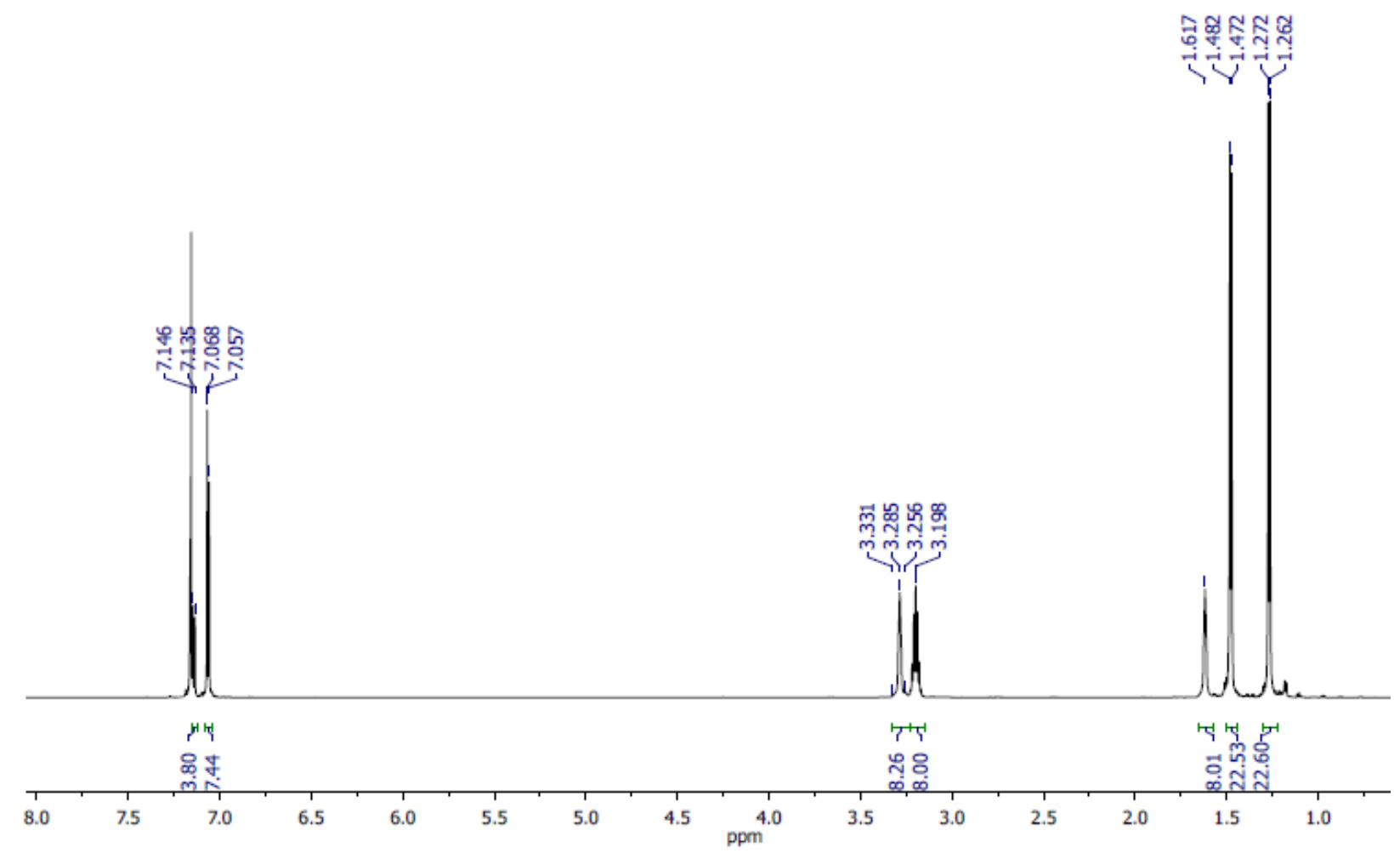

Figure S1. ${ }^{1} \mathrm{H}$ NMR spectrum of $(7 \mathrm{DippCu})_{2} \mathrm{~S}$ in $\mathrm{C}_{6} \mathrm{D}_{6}$.

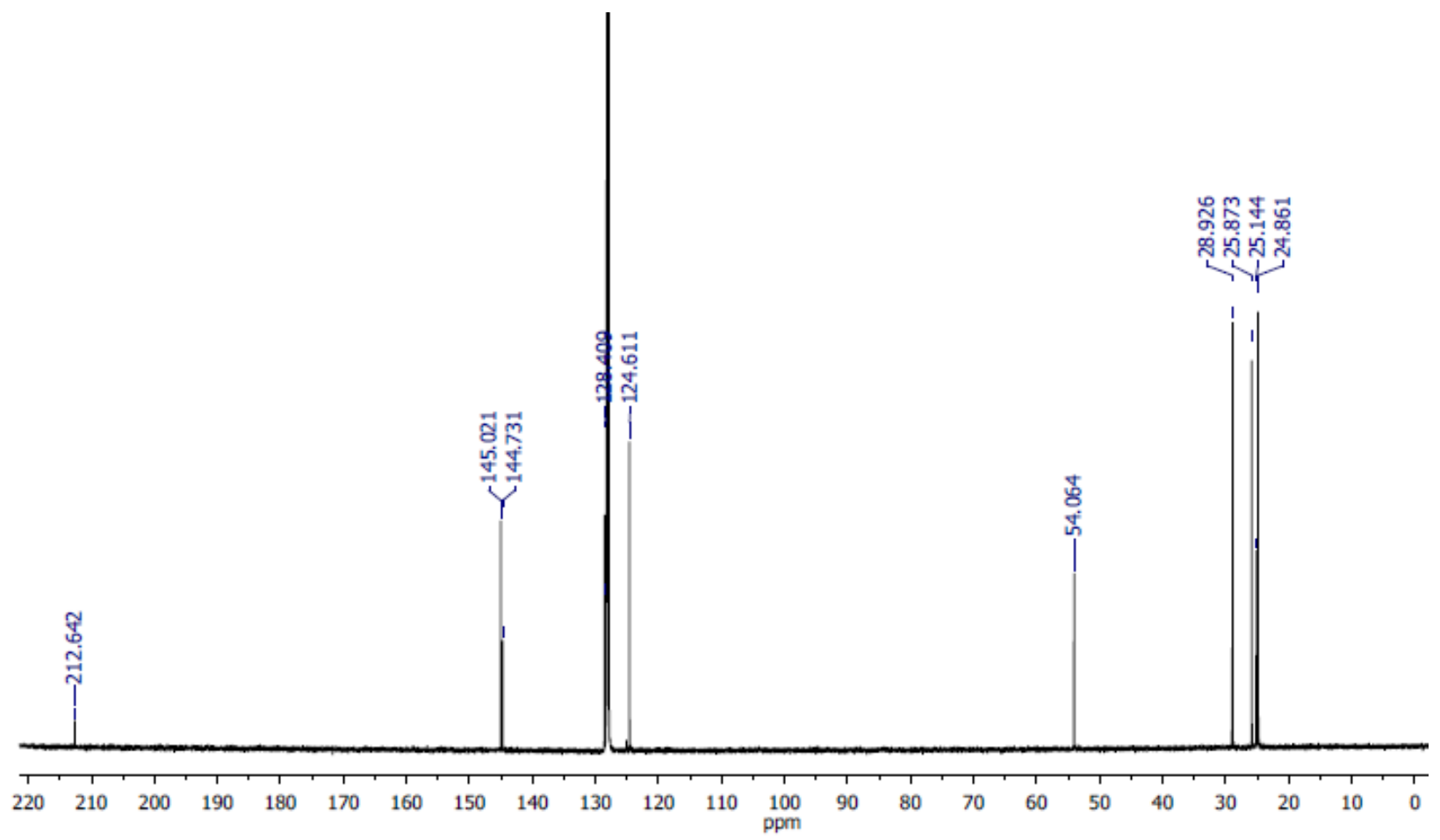

Figure S2. ${ }^{13} \mathrm{C}$ NMR spectrum of $(7 \mathrm{DippCu})_{2} \mathrm{~S}$ in $\mathrm{C}_{6} \mathrm{D}_{6}$. 


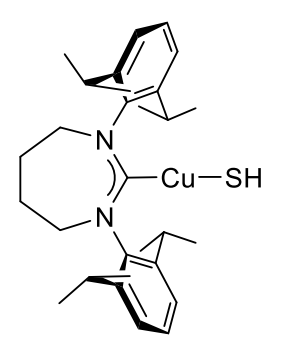

7DippCuSH (2) 7DippCuCl (0.202 g, $0.391 \mathrm{mmol})$ and potassium hydrosulfide (0.034 g, 0.47 mmol) were combined in a 20 -mL vial, equipped with a stir bar, before $\mathrm{MeOH}(5 \mathrm{~mL})$, and THF $(10 \mathrm{~mL})$ were added. The mixture was allowed to stir for $1 \mathrm{~h}$ before the $\mathrm{MeOH}$ and THF were removed in vacuo. The product was extracted with $\mathrm{CH}_{2} \mathrm{Cl}_{2}(3 \times 3 \mathrm{~mL})$ filtered through Celite and concentrated in vacuo to afford the title complex as a colorless solid. $(0.185 \mathrm{~g}, 92 \%$ yield $){ }^{1} \mathrm{H}$ $\operatorname{NMR}\left(700 \mathrm{MHz}, \mathrm{C}_{6} \mathrm{D}_{6}\right): \delta(\mathrm{ppm}) 7.15\left(\mathrm{t},{ }^{3} J_{\mathrm{HH}}=7.7 \mathrm{~Hz}, 2 \mathrm{H}\right.$, para-CH$), 7.04\left(\mathrm{~d},{ }^{3} J_{\mathrm{HH}}=7.7 \mathrm{~Hz}\right.$, $4 \mathrm{H}$, meta- $\mathrm{CH}), 3.27(\mathrm{~m}, 4 \mathrm{H}, \mathrm{NCH})_{2}, 3.21\left(\mathrm{sept},{ }^{3} \mathrm{~J}_{\mathrm{HH}}=7.0 \mathrm{~Hz}, 4 \mathrm{H}, \mathrm{CH}\left(\mathrm{CH}_{3}\right)_{2}\right), 1.63(\mathrm{~m}, 4 \mathrm{H}$, $\left.\mathrm{NCH}_{2} \mathrm{CH}_{2}\right), 1.52\left(\mathrm{~d},{ }^{3} J_{\mathrm{HH}}=7.0 \mathrm{~Hz}, 12 \mathrm{H}, \mathrm{CH}_{2}\left(\mathrm{CH}_{3}\right)_{2}\right), 1.19\left(\mathrm{~d},{ }^{3} \mathrm{~J}_{\mathrm{HH}}=7.0 \mathrm{~Hz}, 12 \mathrm{H}, \mathrm{CH}_{2}\left(\mathrm{CH}_{3}\right)_{2}\right)$, $-2.17(\mathrm{~s}, 1 \mathrm{H}, \mathrm{Cu}-\mathrm{SH}) .{ }^{13} \mathrm{C}\left\{{ }^{1} \mathrm{H}\right\}$ NMR $\left(176 \mathrm{MHz} \mathrm{MHz}, \mathrm{C}_{6} \mathrm{D}_{6}\right): \delta(\mathrm{ppm}) 211.4(\mathrm{NCCu}), 145.2$ (ortho-C), 144.3 (ipso-C), 129.2 (para-C), 125.0 (meta-C), $53.4\left(\mathrm{NCH}_{2}\right), 29.0\left(\mathrm{CH}\left(\mathrm{CH}_{3}\right)_{2}\right)$, 25.2( $\left.\mathrm{NCH}_{2} \mathrm{CH}_{2}\right), 25.1\left(\mathrm{CH}\left(\mathrm{CH}_{3}\right)_{2}\right), 24.8\left(\mathrm{CH}\left(\mathrm{CH}_{3}\right)_{2}\right)$. IR: v $\left(\mathrm{cm}^{-1}\right)$ 2960, 2938, 2865, 1494, 1447, 1385, 1362, 1323, 1309, 1190, 1177, 1095, 1033, 1000, 936, 902, 786, 552, 457. Anal. Calcd for $\mathrm{C}_{29} \mathrm{H}_{43} \mathrm{CuN}_{2} \mathrm{~S}$ C, 67.60; H, 8.41; N, 5.44. Found C, 67.60; H, 8.58; N, 5.40. 


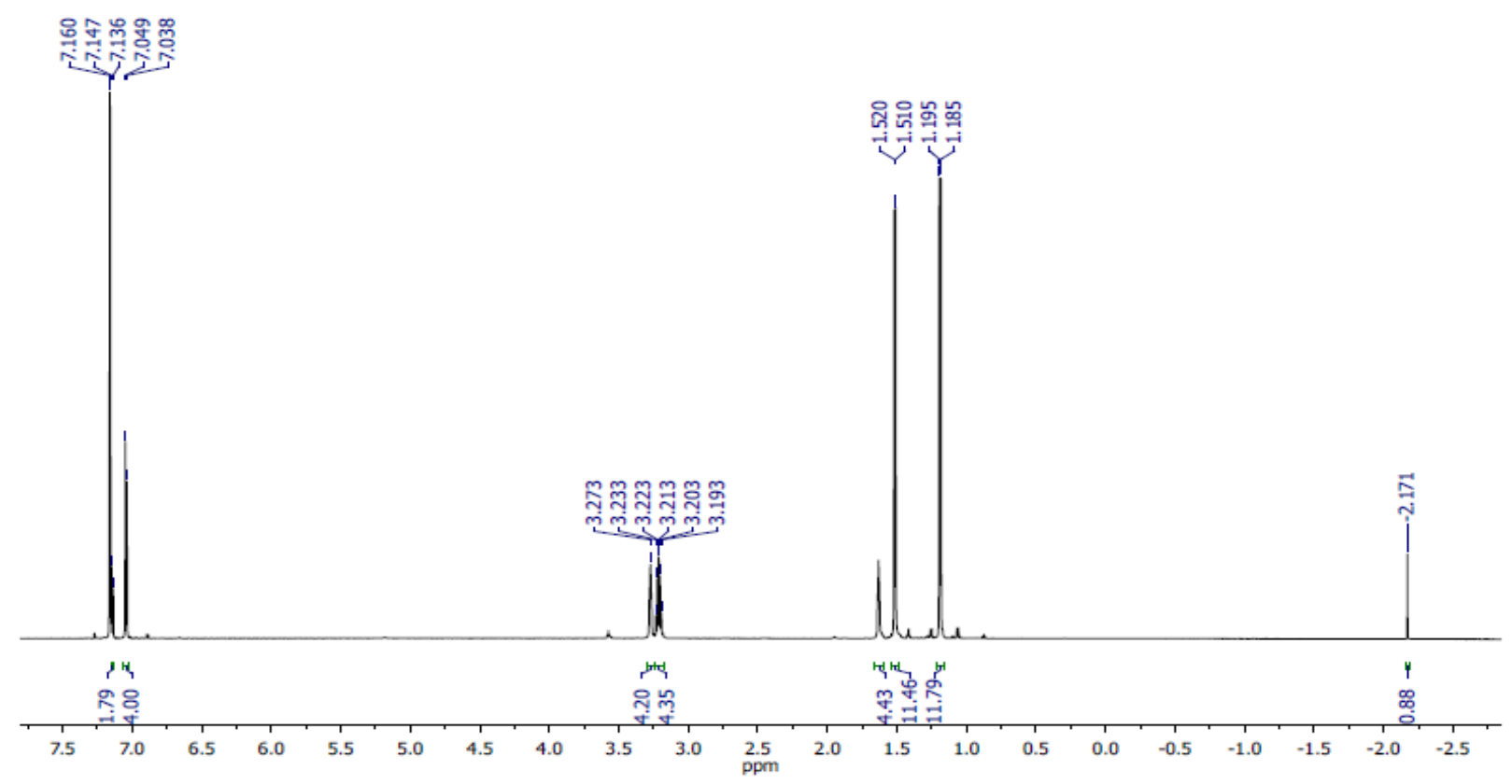

Figure S3. ${ }^{1} \mathrm{H}$ NMR spectrum of 7 DippCuSH in $\mathrm{C}_{6} \mathrm{D}_{6}$.

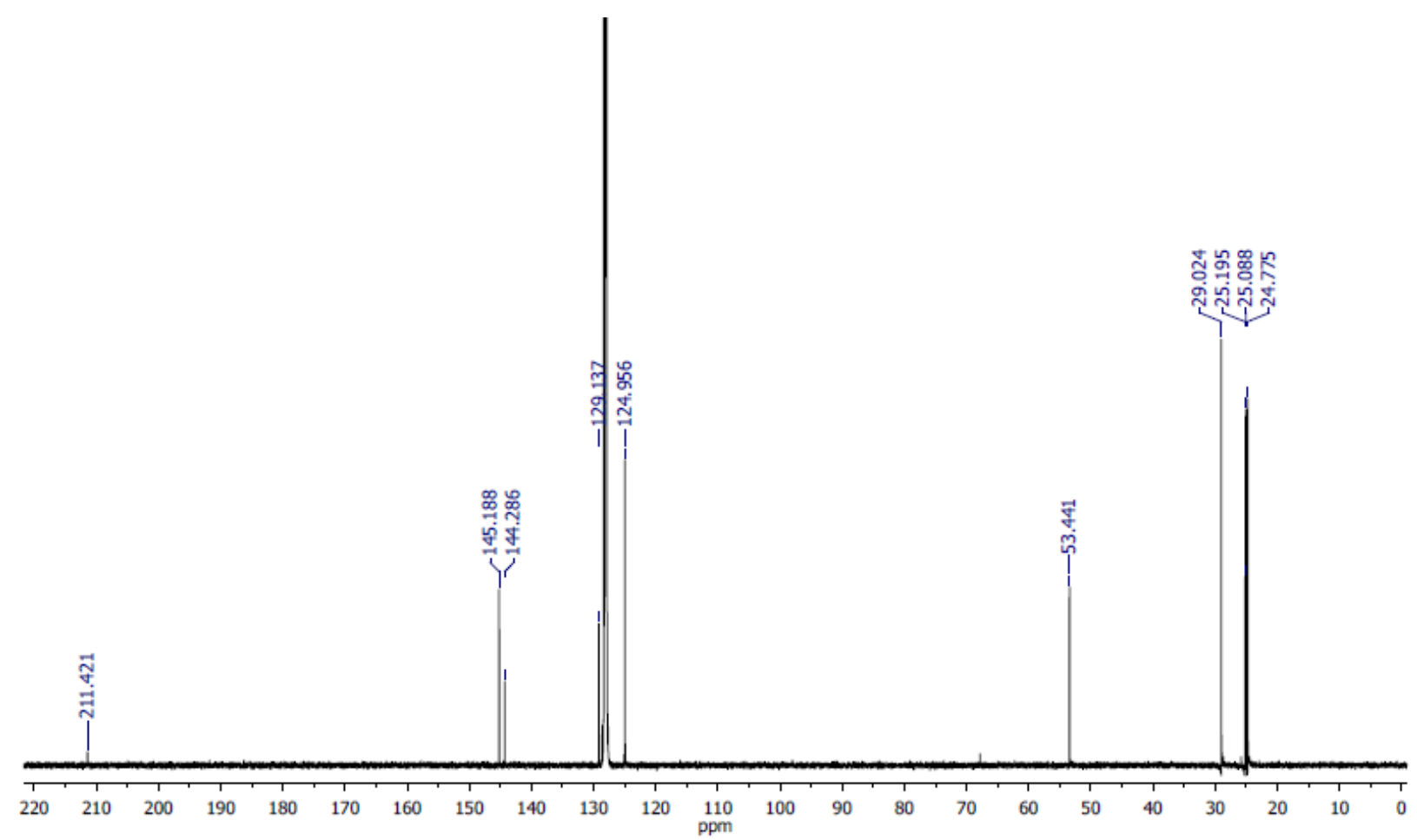

Figure S4. ${ }^{13} \mathrm{C}$ NMR spectrum of 7 DippCuSH in $\mathrm{C}_{6} \mathrm{D}_{6}$. 


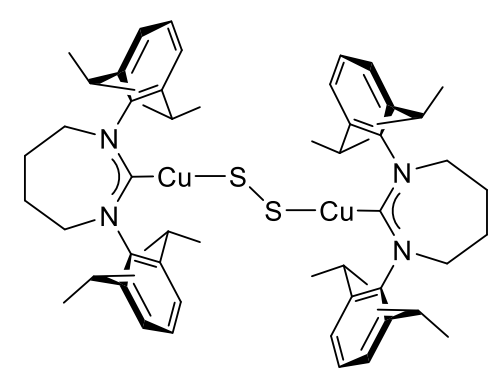

(7DippCuS $)_{2}$ (4) 7DippCuO-t-Bu (0.074 g, $\left.0.13 \mathrm{mmol}\right)$ and 2-phenylacetic dithioperxoyanhydride $(0.020 \mathrm{~g}, 0.066 \mathrm{mmol})$ were combined in a $20-\mathrm{mL}$ vial, equipped with a stir bar, before $\mathrm{C}_{6} \mathrm{H}_{6}(5$ $\mathrm{mL}$ ) were added. The mixture was allowed to stir for $1 \mathrm{~h}$ before the $\mathrm{C}_{6} \mathrm{H}_{6}$ was removed in vacuo. The resulting yellow solid was washed with pentane $(3 \times 3 \mathrm{~mL})$, the recrystallized from $\mathrm{CH}_{3} \mathrm{CN}$ $(5 \mathrm{~mL})$ at $-35^{\circ} \mathrm{C}$. The resulting solid was dried under in vacuo to afford the product as an orange solid. (0.040 g, 58\% yield) ${ }^{1} \mathrm{H}$ NMR (700 MHz, $\left.\mathrm{C}_{6} \mathrm{D}_{6}\right): \delta(\mathrm{ppm}) 7.17\left(\mathrm{t},{ }^{3} \mathrm{~J}_{\mathrm{HH}}=7.7 \mathrm{~Hz}, 4 \mathrm{H}\right.$, para$\mathrm{CH}), 7.07\left(\mathrm{~d},{ }^{3} J_{\mathrm{HH}}=7.7 \mathrm{~Hz}, 8 \mathrm{H}\right.$, meta- $\left.\mathrm{CH}\right), 3.32\left(\mathrm{~m}, 8 \mathrm{H}, \mathrm{NCH}_{2}\right), 3.23\left(\mathrm{sept},{ }^{3} J_{\mathrm{HH}}=7.0 \mathrm{~Hz}, 8 \mathrm{H}\right.$, $\left.\mathrm{CH}\left(\mathrm{CH}_{3}\right)_{2}\right), 1.64\left(\mathrm{~m}, 8 \mathrm{H}, \mathrm{NCH}_{2} \mathrm{CH}_{2}\right), 1.54\left(\mathrm{~d},{ }^{3} J_{\mathrm{HH}}=7.0 \mathrm{~Hz}, 24 \mathrm{H}, \mathrm{CH}_{2}\left(\mathrm{CH}_{3}\right)_{2}\right), 1.25\left(\mathrm{~d},{ }^{3} J_{\mathrm{HH}}=7.0\right.$ $\left.\mathrm{Hz}, 24 \mathrm{H}, \mathrm{CH}_{2}\left(\mathrm{CH}_{3}\right)_{2}\right) \cdot{ }^{13} \mathrm{C}\left\{{ }^{1} \mathrm{H}\right\}$ NMR (176 MHz MHz, $\left.\mathrm{C}_{6} \mathrm{D}_{6}\right): \delta(\mathrm{ppm}) 213.9(\mathrm{NCCu}), 145.0$ (ortho-C), 144.7 (ipso-C), 128.8 (para-C), 125.0 (meta-C), $53.6\left(\mathrm{NCH}_{2}\right), 29.1\left(\mathrm{CH}\left(\mathrm{CH}_{3}\right)_{2}\right), 25.4$ $\left(\mathrm{CH}\left(\mathrm{CH}_{3}\right)_{2}\right), 25.2\left(\mathrm{NCH}_{2} \mathrm{CH}_{2}\right), 25.0\left(\mathrm{CH}\left(\mathrm{CH}_{3}\right)_{2}\right)$. IR: $v\left(\mathrm{~cm}^{-1}\right) 2957,2926,2865,1498,1446,1385$, 1363, 1312, 1290, 1222, 1096, 1055, 935, 899, 801, 756, 629, 504, 406.

Note: We have been unable to obtain satisfactory elemental analysis for 4 . The complex is extremely air-and moisture-sensitive. While NMR-silent impurities cannot be ruled out, we believe the ${ }^{1} \mathrm{H}$ and ${ }^{13} \mathrm{C}$ NMR spectra provided reflect the purity of the sample. 


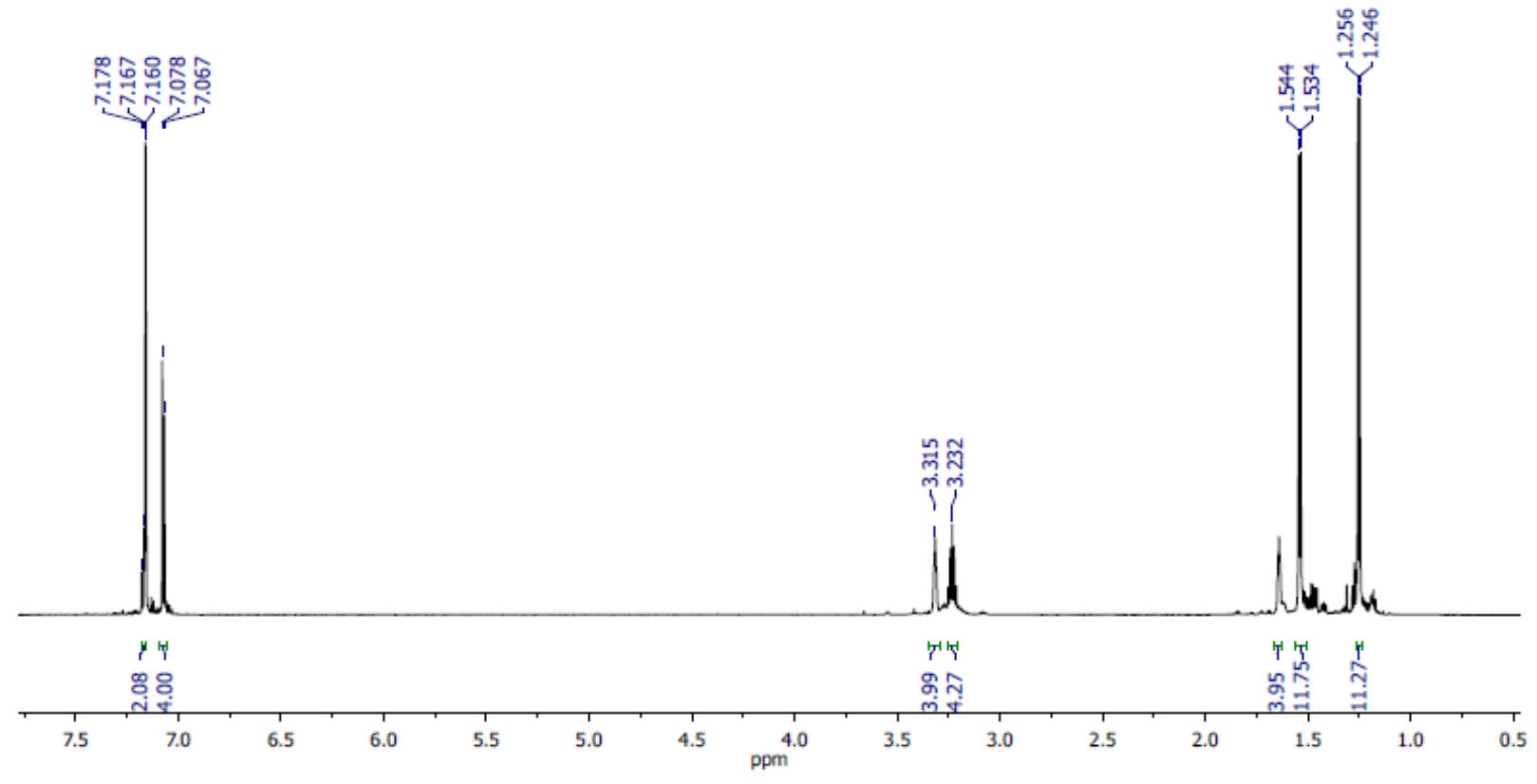

Figure S5. ${ }^{1} \mathrm{H}$ NMR spectrum of $(7 \mathrm{DippCuS})_{2}$ in $\mathrm{C}_{6} \mathrm{D}_{6}$.

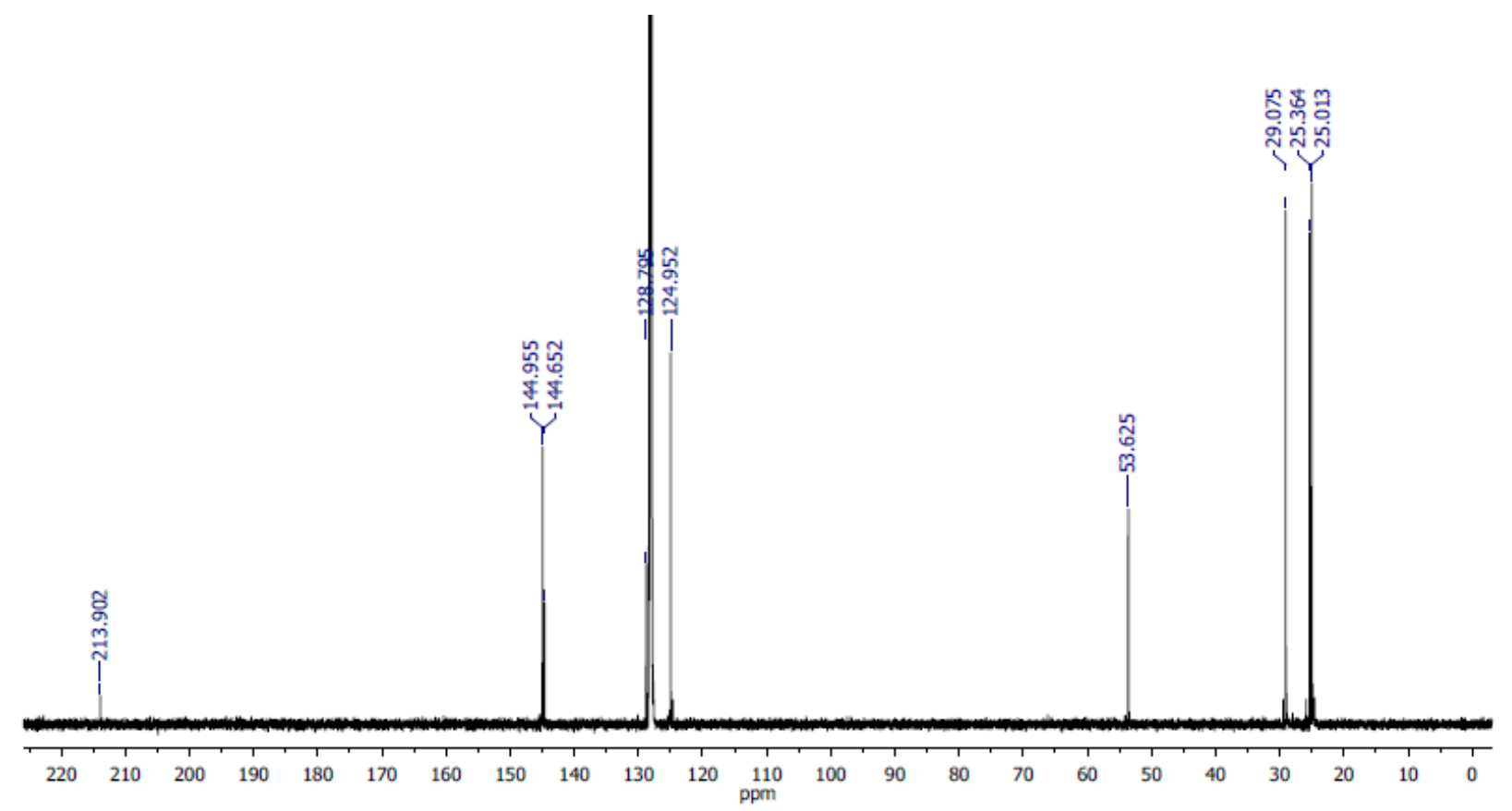

Figure S6. ${ }^{13} \mathrm{C}$ NMR spectrum of $(7 \mathrm{DippCuS})_{2}$ in $\mathrm{C}_{6} \mathrm{D}_{6}$. 


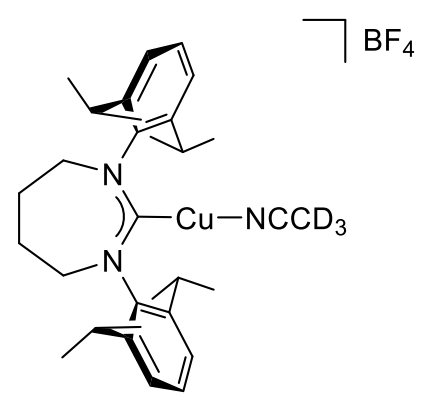

7DippCu( $\left.\mathbf{N C C D}_{3}\right) \mathbf{B F}_{4}(\mathbf{5}) 7 \mathrm{DippCuCl}(0.059 \mathrm{~g}, 0.11 \mathrm{mmol})$ and silver tetrafluoroborate $(0.022 \mathrm{~g}$, $0.11 \mathrm{mmol}$ ) were combined in a $20-\mathrm{mL}$ vial, equipped with a stir bar, before $\mathrm{CD}_{3} \mathrm{CN}(0.1 \mathrm{~mL})$ and DCM $(3 \mathrm{~mL})$ were added. The mixture was allowed to stir for $15 \mathrm{~min}$, filtered through Celite, and concentrated in vacuo. The resulting colorless solid was dissolved in ethyl acetate $(3 \mathrm{~mL})$, layered with hexanes $(5 \mathrm{~mL})$ and placed in the freezer overnight. The resulting colorless solid was collected and dried in vacuo to afford the title complex. (0.051 g, 74\% yield) ${ }^{1} \mathrm{H}$ NMR (700 MHz, $\left.\mathrm{CD}_{3} \mathrm{CN}\right): \delta(\mathrm{ppm}) 7.33\left(\mathrm{t},{ }^{3} J_{\mathrm{HH}}=7.7 \mathrm{~Hz}, 2 \mathrm{H}\right.$, para- $\left.\mathrm{CH}\right), 7.26\left(\mathrm{~d},{ }^{3} J_{\mathrm{HH}}=7.7 \mathrm{~Hz}, 4 \mathrm{H}\right.$, meta-CH), 3.98 (m, 4H, NCH 2$), 3.30\left(\mathrm{sept},{ }^{3} J_{\mathrm{HH}}=7.0 \mathrm{~Hz}, 4 \mathrm{H}, \mathrm{CH}\left(\mathrm{CH}_{3}\right)_{2}\right), 2.29\left(\mathrm{~m}, 4 \mathrm{H}, \mathrm{NCH}_{2} \mathrm{CH}_{2}\right), 1.29\left(\mathrm{~d},{ }^{3} J_{\mathrm{HH}}\right.$ $\left.=7.0 \mathrm{~Hz}, 12 \mathrm{H}, \mathrm{CH}_{2}\left(\mathrm{CH}_{3}\right)_{2}\right) 1.27\left(\mathrm{~d},{ }^{3} J_{\mathrm{HH}}=7.0 \mathrm{~Hz}, 12 \mathrm{H}, \mathrm{CH}_{2}\left(\mathrm{CH}_{3}\right)_{2}\right){ }^{13} \mathrm{C}\left\{{ }^{1} \mathrm{H}\right\} \mathrm{NMR}(176 \mathrm{MHz}$ $\left.\mathrm{CD}_{3} \mathrm{CN}\right): \delta(\mathrm{ppm}) 213.2(\mathrm{NCCu}), 146.4$ (ortho-C), 146.2 (ipso-C), 129.4 (para-C), 125.5 (metaC), $55.1\left(\mathrm{NCH}_{2}\right), 29.3\left(\mathrm{CH}\left(\mathrm{CH}_{3}\right)_{2}\right), 26.0\left(\mathrm{NCH}_{2} \mathrm{CH}_{2}\right), 25.1\left(\mathrm{CH}\left(\mathrm{CH}_{3}\right)_{2}\right), 24.4\left(\mathrm{CH}\left(\mathrm{CH}_{3}\right)_{2}\right) .{ }^{19} \mathrm{~F}$ NMR (378 MHz, $\left.\mathrm{CD}_{3} \mathrm{CN}\right): \delta(\mathrm{ppm})-152.4\left(4 \mathrm{~F}, \mathrm{~B} F_{4}^{-}\right) . \mathrm{IR}: v\left(\mathrm{~cm}^{-1}\right)$ 2967, 2931, 2865, 1487, 1449, 1383, 1362, 1308, 1095, 1053, 1002, 934, 806, 790, 763, 612, 557, 518, 490. 


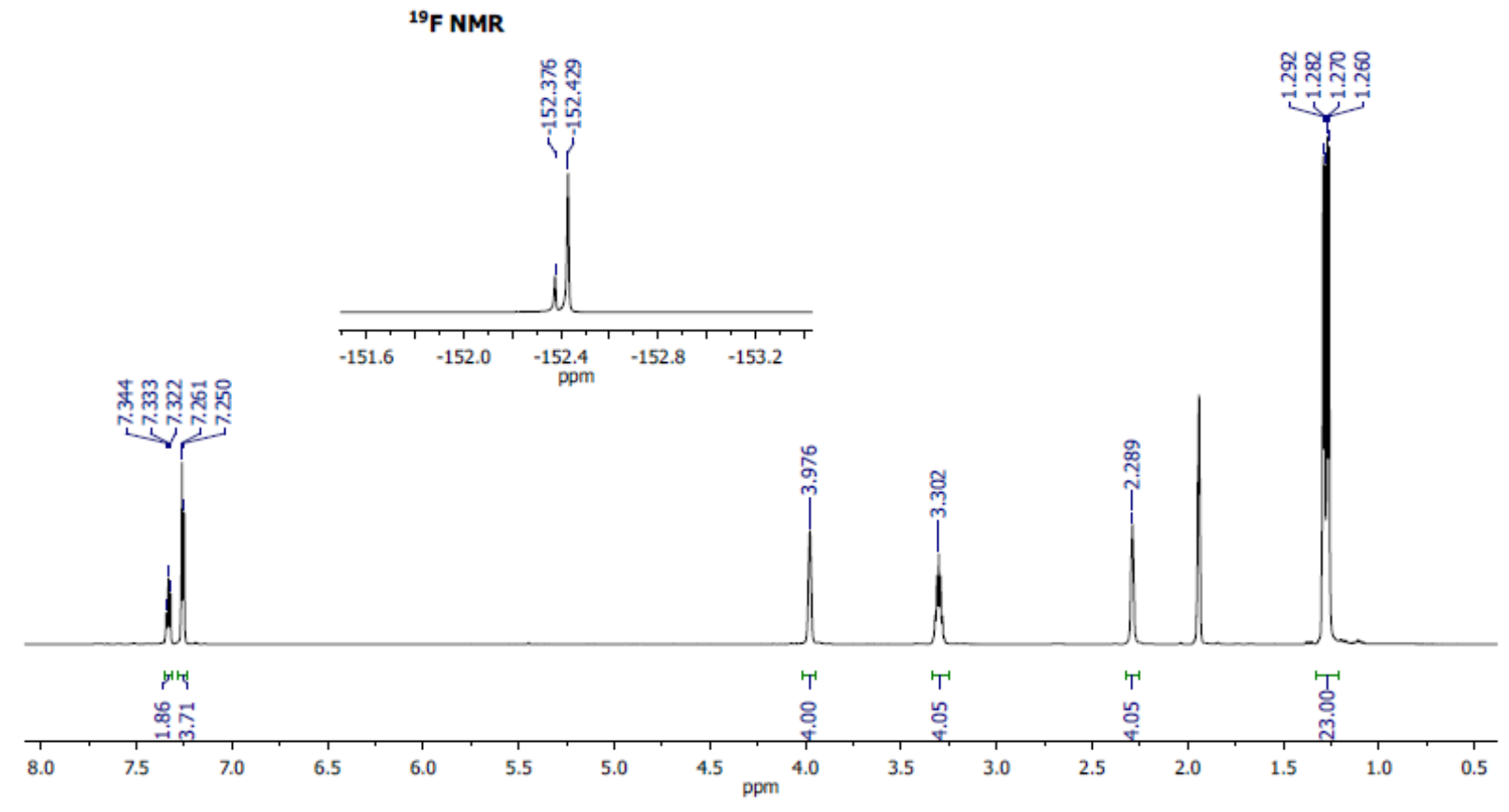

Figure S7. ${ }^{1} \mathrm{H}$ NMR spectrum of $7 \mathrm{DippCu}\left(\mathrm{NCCD}_{3}\right) \mathrm{BF}_{4}$ overlaid with the $\mathrm{BF}_{4}{ }^{-}$resonance in ${ }^{19} \mathrm{~F}$ NMR spectrum in $\mathrm{CD}_{3} \mathrm{CN}$.

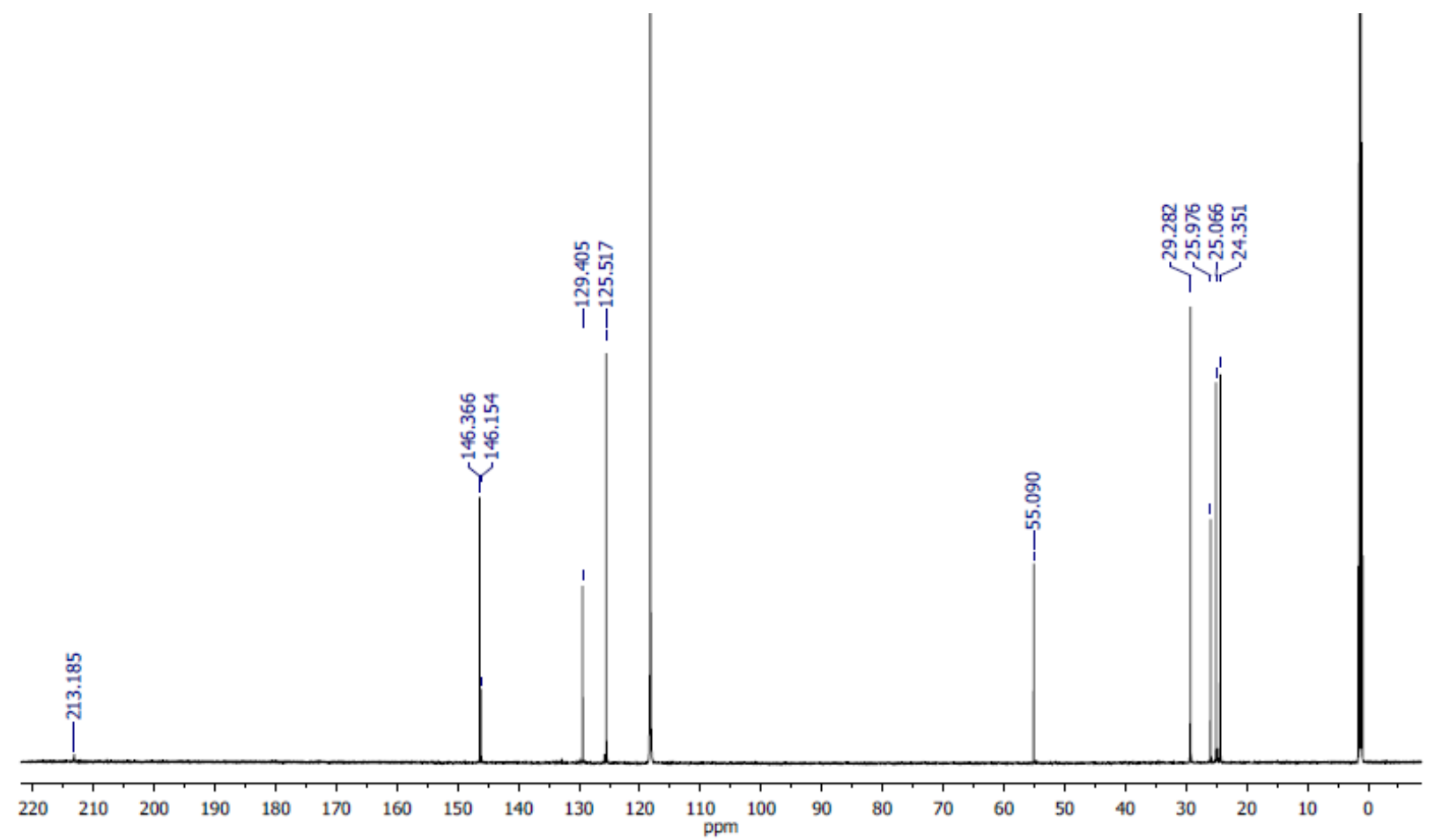

Figure S8. ${ }^{13} \mathrm{C}$ NMR spectrum of $7 \mathrm{DippCu}\left(\mathrm{NCCD}_{3}\right) \mathrm{BF}_{4}$ in $\mathrm{CD}_{3} \mathrm{CN}$. 


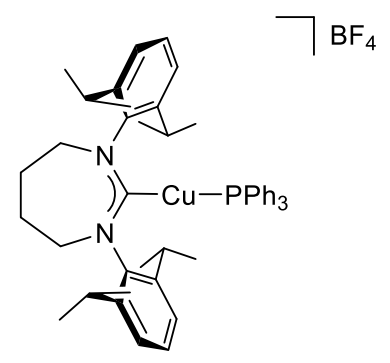

7DippCu(PPh $) \mathbf{B F}_{4}$ 7DippCuCl (0.067 g, $\left.0.13 \mathrm{mmol}\right)$, triphenylphosphine $(0.034,0.13 \mathrm{mmol})$ and silver tetrafluoroborate $(0.025 \mathrm{~g}, 0.13 \mathrm{mmol})$ were combined in a $20-\mathrm{mL}$ vial, equipped with a stir bar, before DCM $(5 \mathrm{~mL})$ was added. The mixture was allowed to stir for $15 \mathrm{~min}$, filtered thought Celite, before the resulting colorless solution was layered with pentane $(8 \mathrm{~mL})$ and placed in the freezer at $-35^{\circ} \mathrm{C}$ for $16 \mathrm{~h}$. The resulting crystals were dried in vacuo for $1 \mathrm{~h}$ to afford the title complex. (0.090 g, $84 \%$ yield) ${ }^{1} \mathrm{H}$ NMR (400 MHz, $\mathrm{CD}_{2} \mathrm{Cl}_{2}$ ): $\delta(\mathrm{ppm})$ 7.48-7.44 (m, 4H, dipp para- $\mathrm{CH}, \mathrm{PPh}_{3}$ para-CH), 7.32-7.26 (m, 10H, dipp meta-CH, $\mathrm{PPh}_{3}$ meta-CH), 6.63-6.58 (m, $\mathrm{PPh}_{3}$ ortho- $\mathrm{CH}), 4.07\left(\mathrm{~m}, 4 \mathrm{H}, \mathrm{NCH}_{2}\right), 3.27\left(\mathrm{sept},{ }^{3} \mathrm{~J}_{\mathrm{HH}}=6.8 \mathrm{~Hz}, 4 \mathrm{H}, \mathrm{CH}\left(\mathrm{CH}_{3}\right)_{2}\right), 2.40(\mathrm{~m}, 4 \mathrm{H}$, $\left.\mathrm{NCH}_{2} \mathrm{CH}_{2}\right), 1.33\left(\mathrm{~d},{ }^{3} J_{\mathrm{HH}}=6.8 \mathrm{~Hz}, 12 \mathrm{H}, \mathrm{CH}_{2}\left(\mathrm{CH}_{3}\right)_{2}\right), 1.05\left(\mathrm{~d},{ }^{3} J_{\mathrm{HH}}=6.8 \mathrm{~Hz}, 12 \mathrm{H}, \mathrm{CH}_{2}\left(\mathrm{CH}_{3}\right)_{2}\right)$. ${ }^{13} \mathrm{C}\left\{{ }^{1} \mathrm{H}\right\}$ NMR $\left(176 \mathrm{MHz} \mathrm{CD}_{2} \mathrm{Cl}_{2}\right): \delta(\mathrm{ppm}) 206.1\left(\mathrm{~d},{ }^{2} J_{\mathrm{PC}}=60.2 \mathrm{~Hz}, \mathrm{NCCu}\right), 146.0$ (dipp orthoC), $143.8\left(\right.$ dipp ipso-C), $133.7\left(\mathrm{~d},{ }^{2} J_{\mathrm{PC}}=14.1 \mathrm{~Hz}, \mathrm{PPh}_{3}\right.$ ortho-C), $131.9\left(\mathrm{~d},{ }^{4} J_{\mathrm{PC}}=2.1 \mathrm{~Hz}, \mathrm{PPh}_{3}\right.$ para-C), $130.1($ para-C $), 129.6\left(\mathrm{~d},{ }^{3} J_{\mathrm{PC}}=5.5 \mathrm{~Hz}, \mathrm{PPh}_{3}\right.$ para-C $), 127.8\left(\mathrm{~d},{ }^{1} J_{\mathrm{PC}}=45.9 \mathrm{~Hz}, \mathrm{PPh}_{3}\right.$ ipso-C), 125.8 (dipp meta-C) $55.0\left(\mathrm{NCH}_{2}\right), 29.2\left(\mathrm{CH}\left(\mathrm{CH}_{3}\right)_{2}\right), 25.5\left(\mathrm{NCH}_{2} \mathrm{CH}_{2}\right), 25.2\left(\mathrm{CH}\left(\mathrm{CH}_{3}\right)_{2}\right)$, $24.7\left(\mathrm{CH}\left(\mathrm{CH}_{3}\right)_{2}\right) .{ }^{31} \mathrm{P}\left\{{ }^{1} \mathrm{H}\right\}$ NMR $\left(162 \mathrm{MHz}, \mathrm{CD}_{2} \mathrm{Cl}_{2}\right): \delta(\mathrm{ppm}) 7.7\left(\mathrm{Cu}-\mathrm{PPh}_{3}\right) .{ }^{19} \mathrm{~F}$ NMR $(378$ $\left.\mathrm{MHz}, \mathrm{CD}_{2} \mathrm{Cl}_{2}\right): \delta(\mathrm{ppm})-152.7\left(4 \mathrm{~F}, \mathrm{~B}_{4}^{-}\right) . \mathrm{IR}: v\left(\mathrm{~cm}^{-1}\right) 2961,2922,2845,1506,1436,1315,1094$, 1046, 998, 900, 807, 748, 675, 530, 506, 489, 451. Anal. Calcd for $\mathrm{C}_{47} \mathrm{H}_{57} \mathrm{CuN}_{2} \mathrm{BF}_{4} \mathrm{P} \mathrm{C}, 67.91 ; \mathrm{H}$, 6.91; N, 3.37. Found C, 67.45; H, 6.73; N, 3.47. 


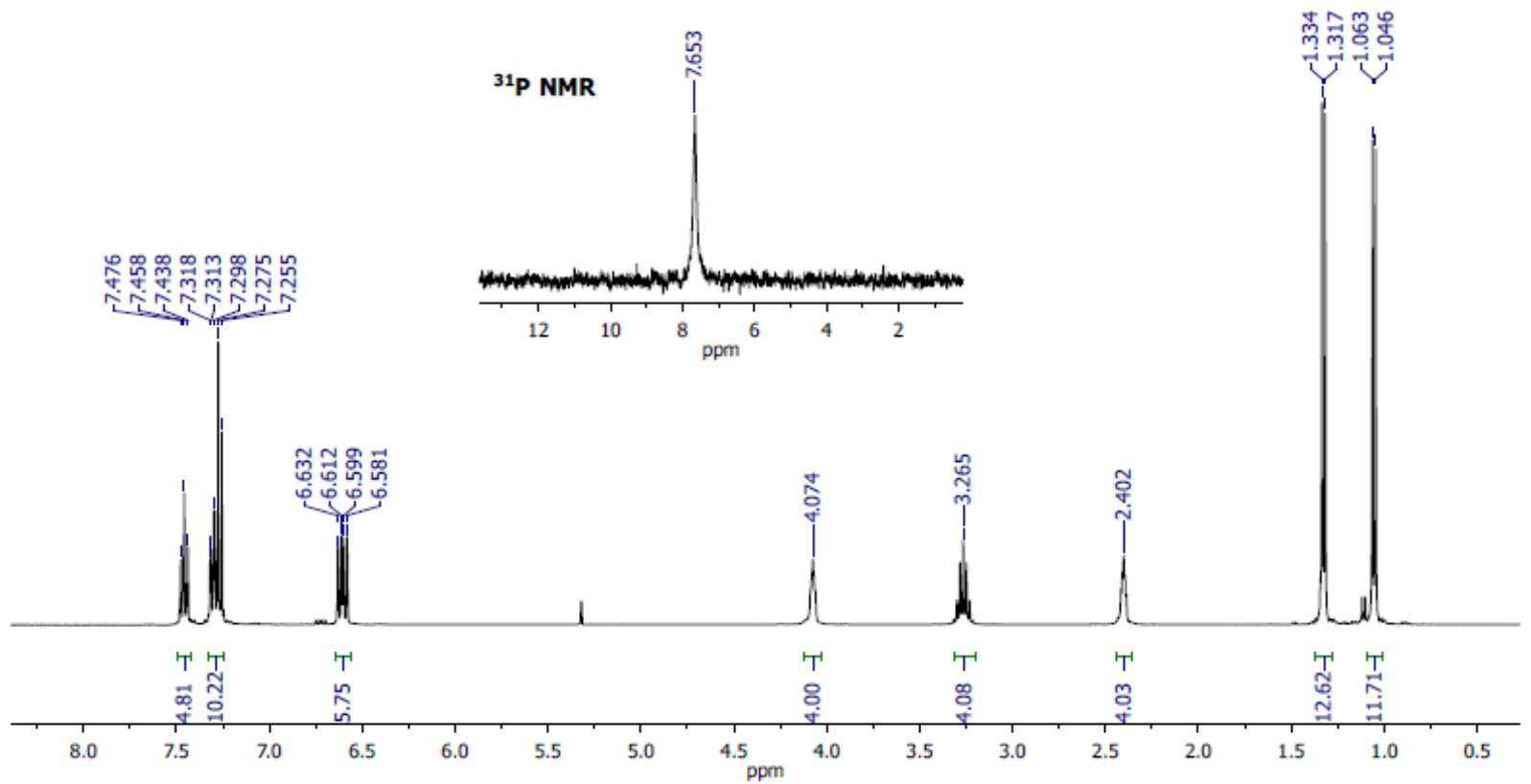

Figure S9. ${ }^{1} \mathrm{H}$ and ${ }^{31} \mathrm{P} \mathrm{NMR}$ spectra of $7 \mathrm{DippCu}\left(\mathrm{PPh}_{3}\right) \mathrm{BF}_{4}$ in $\mathrm{CD}_{2} \mathrm{Cl}_{2}$.

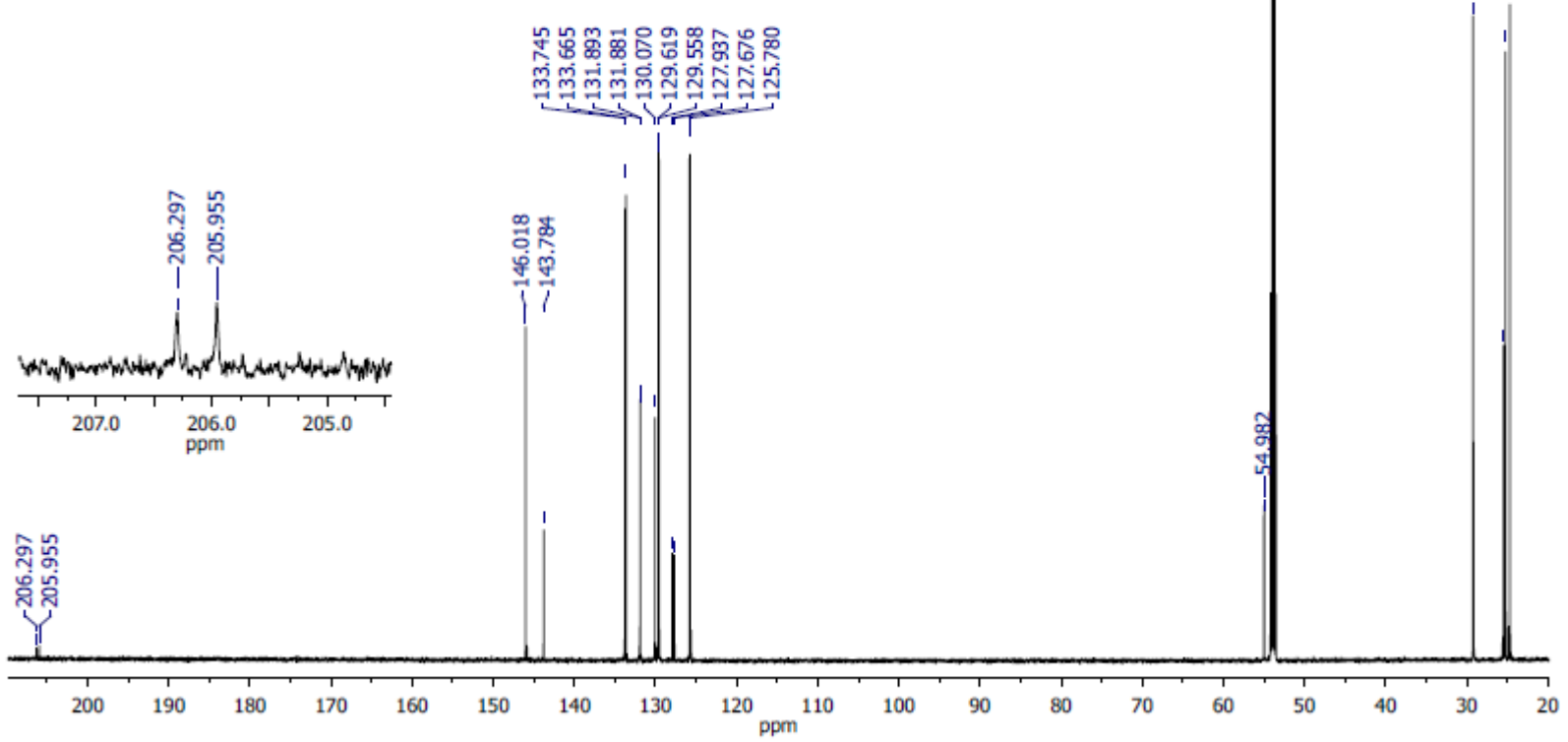

Figure S10. ${ }^{13} \mathrm{C}$ NMR spectrum of $7 \mathrm{DippCu}\left(\mathrm{PPh}_{3}\right) \mathrm{BF}_{4}$ in $\mathrm{CD}_{2} \mathrm{Cl}_{2}$. 
Deprotonation of $\mathbf{2}$ by $\mathbf{3}$.

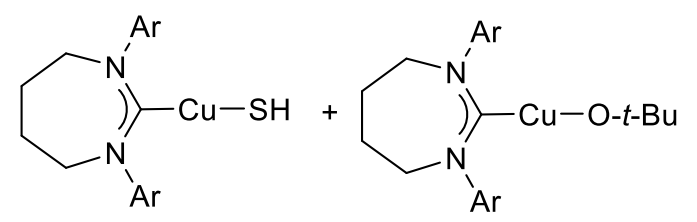

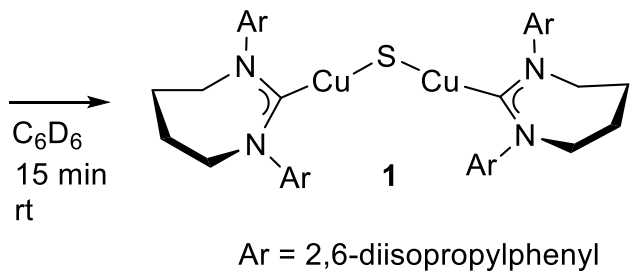

7DippCuSH (2, $0.013 \mathrm{~g}, 0.025 \mathrm{mmol})$ and 7DippCuO-t-Bu (3, $0.014 \mathrm{~g}, 0.025 \mathrm{mmol})$ were dissolved in $\mathrm{C}_{6} \mathrm{D}_{6}(0.75 \mathrm{~mL})$ and mixed for $15 \mathrm{~min}$ before the ${ }^{1} \mathrm{H}$ NMR spectrum was recorded.

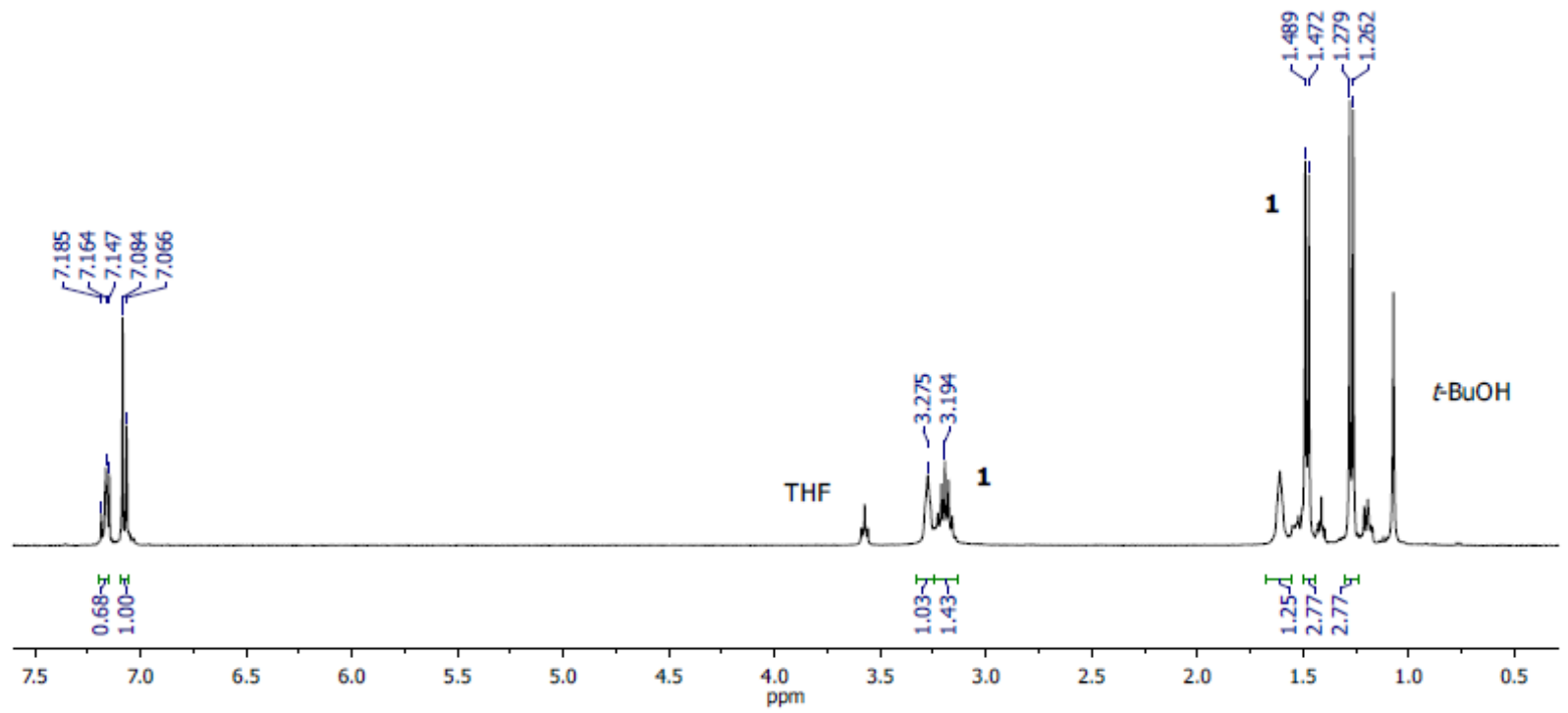

Figure S11. ${ }^{1} \mathrm{H}$ NMR spectrum of reaction of $\mathbf{2}$ and $\mathbf{3}$. 
Deprotonation of 2 by $\mathrm{NaO}-t-\mathrm{Bu}$.

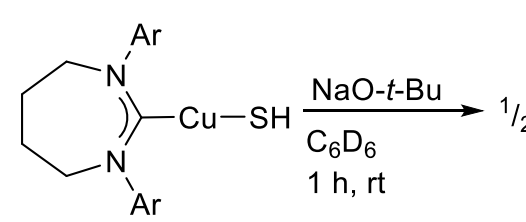

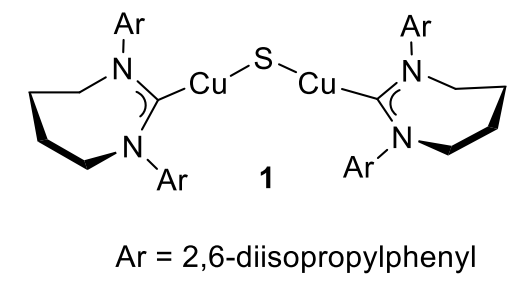

7DippCuSH (2, $0.028 \mathrm{~g}, 0.054 \mathrm{mmol})$ and $\mathrm{NaO}-t$-Bu $(0.010 \mathrm{~g}, 0.010 \mathrm{mmol})$ were dissolved in $\mathrm{C}_{6} \mathrm{D}_{6}(0.75 \mathrm{~mL})$ and mixed for $1 \mathrm{~h}$ before the ${ }^{1} \mathrm{H}$ NMR spectrum was recorded.

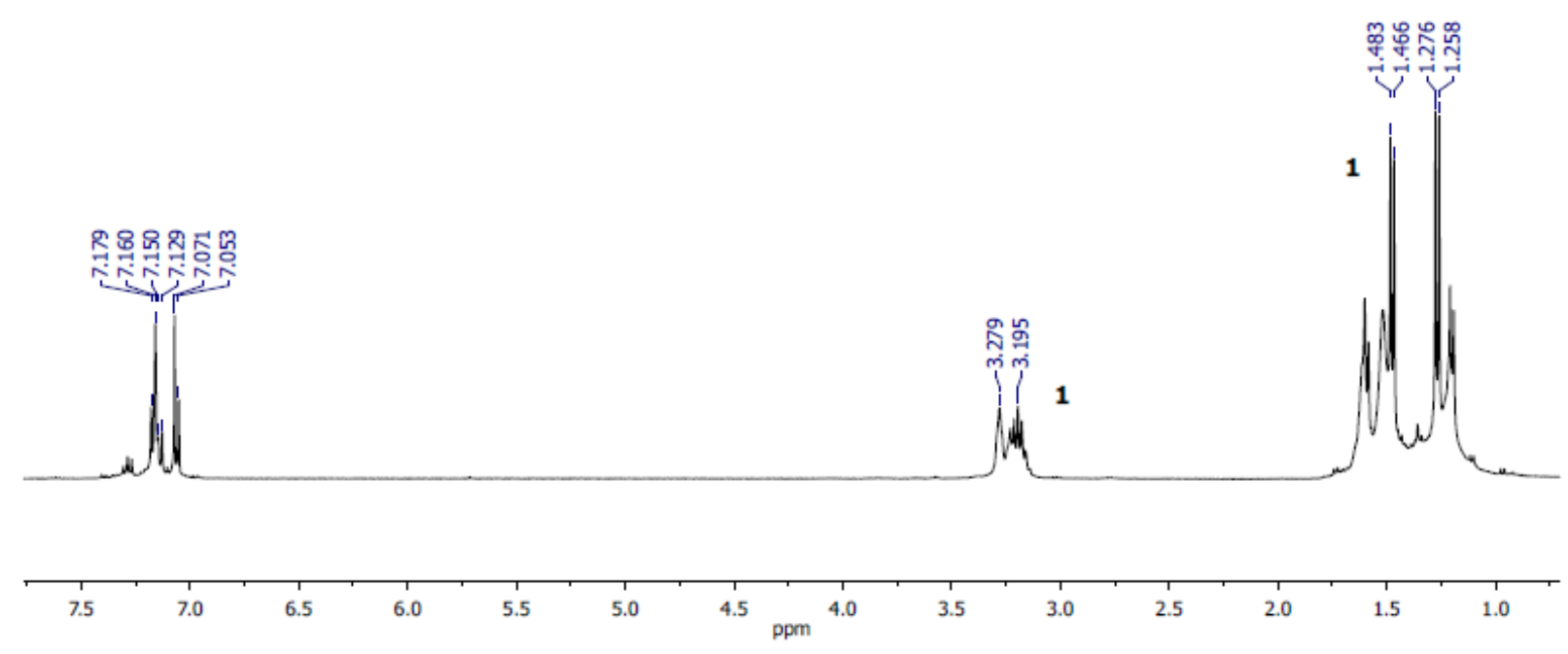

Figure S12. ${ }^{1} \mathrm{H}$ NMR spectrum of reaction of 2 and $\mathrm{NaO}-t-\mathrm{Bu}$. 
Conversion of 1 to $7 \mathrm{DippCuCl}$ and tetrahydrothiophene for elemental analysis.

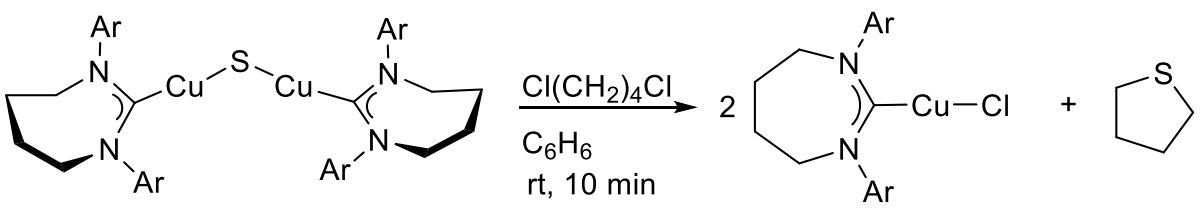

$\operatorname{Ar}=2,6$-diisopropylphenyl

1,4-Dichlorobutane $(11 \mu \mathrm{L}, 0.10 \mathrm{mmol})$ was added to a solution of (7DippCu $)_{2} \mathrm{~S}(0.020 \mathrm{~g}, 0.020$ mmol) in $\mathrm{C}_{6} \mathrm{D}_{6}(2 \mathrm{~mL})$ and mixed for $10 \mathrm{~min}$. The solution was then concentrated in vacuo and a small amount was dissolved in $\mathrm{CDCl}_{3}$ and the ${ }^{1} \mathrm{H}$ NMR spectrum was recorded. The solid was dried under vacuum for $48 \mathrm{~h}$ to remove the excess 1,4-dichlorobutane. Anal. Calcd for $\mathrm{C}_{29} \mathrm{H}_{42} \mathrm{ClCuN}_{2}: \mathrm{C}, 67.29 ; \mathrm{H}, 8.18 ; \mathrm{N}$, 5.41. Found C, 67.19; H, 8.17; N, 5.28.

Note: Hillhouse and coworkers had previously shown that the $\operatorname{IPr}^{*}-\left(\operatorname{IPr}^{*}=1,3-\operatorname{bis}(2,6-\right.$ (diphenylmethyl)-4-methylphenyl)imidazol-2-ylidene) supported dicopper sulfide reacts with dibromoalkanes to generate the corresponding (NHC)copper(I) bromide and cyclic thioether. ${ }^{2}$ 
Conversion of 4 to 1

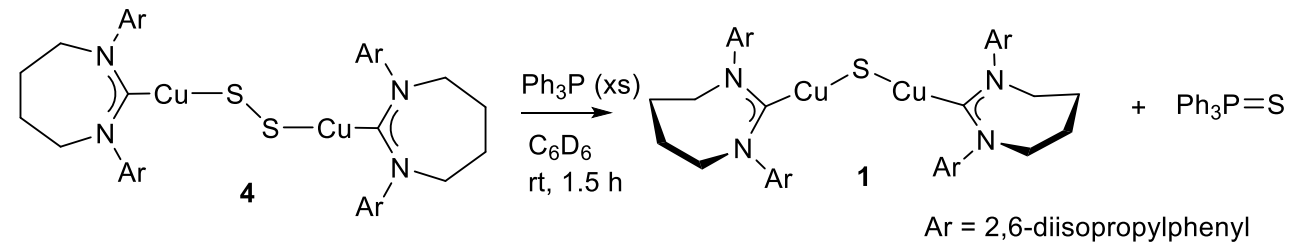

(7DippCuS $)_{2}(4,0.010 \mathrm{~g}, 0.0097 \mathrm{mmol})$ was dissolved in $\mathrm{C}_{6} \mathrm{D}_{6}$ and a ${ }^{1} \mathrm{H}$ NMR spectrum was recorded. Triphenylphosphine $\left(\mathrm{Ph}_{3} \mathrm{P}, 0.009 \mathrm{~g}, 0.03 \mathrm{mmol}\right)$ was added and the ${ }^{1} \mathrm{H}$ and ${ }^{31} \mathrm{P}$ NMR spectra were recorded after $1.5 \mathrm{~h}$.

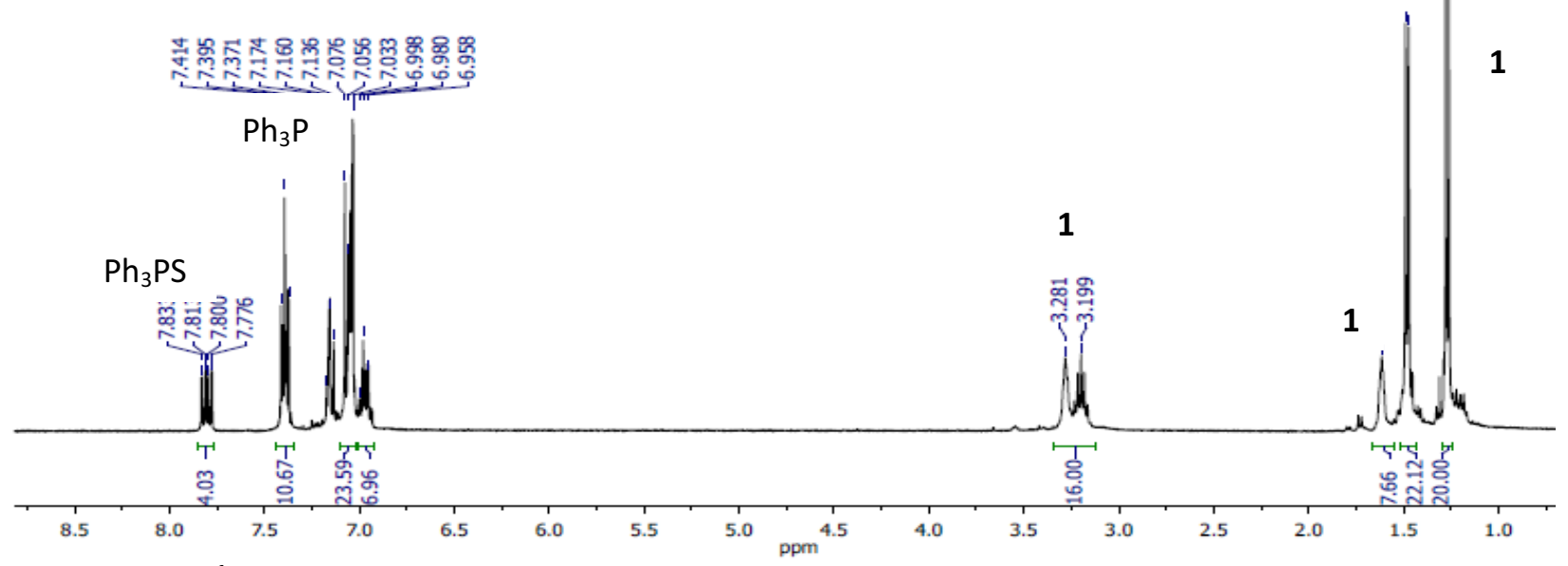

Figure S13. ${ }^{1} \mathrm{H}$ NMR spectrum after $\mathrm{Ph}_{3} \mathrm{P}$ was added to 4 , generating 1 and $\mathrm{Ph}_{3} \mathrm{PS}$.

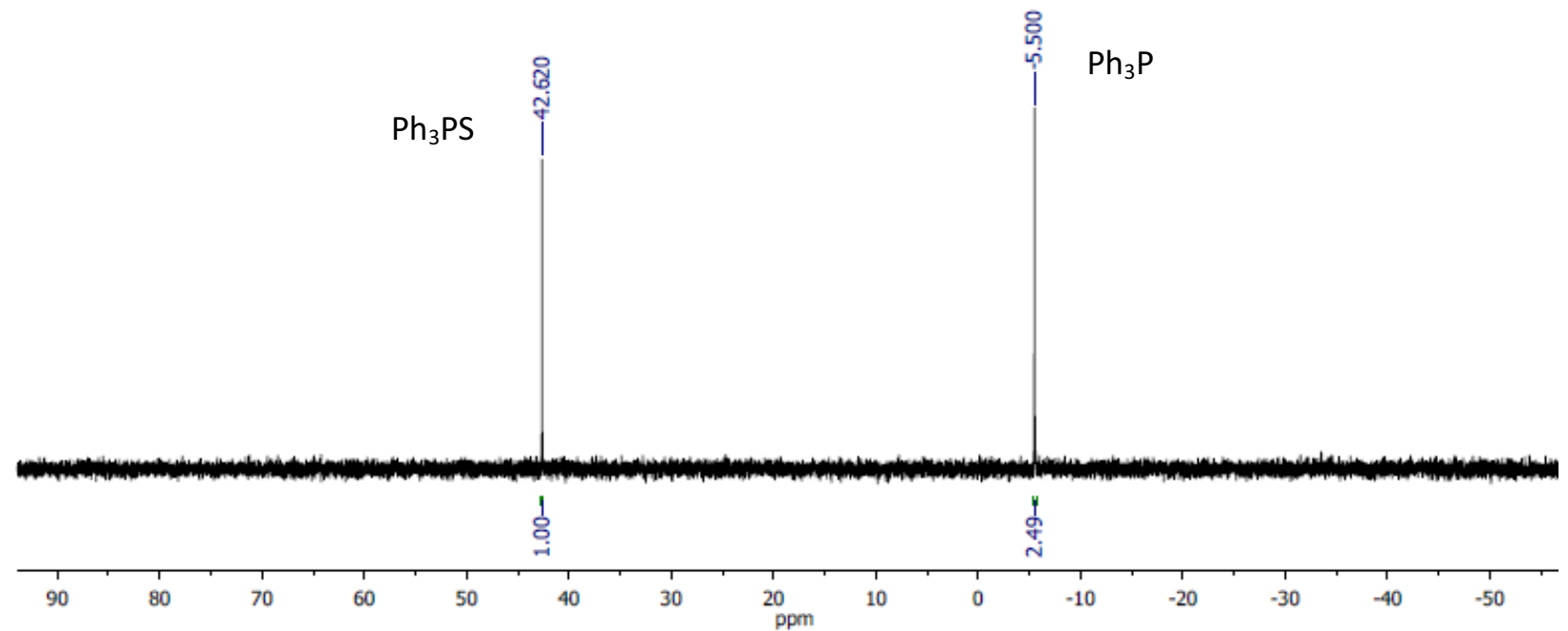

Figure S14. ${ }^{13} \mathrm{P}$ NMR spectrum after $\mathrm{Ph}_{3} \mathrm{P}$ was added to 4 . 
Nitrosonium reactivity of $\mathbf{2}$.

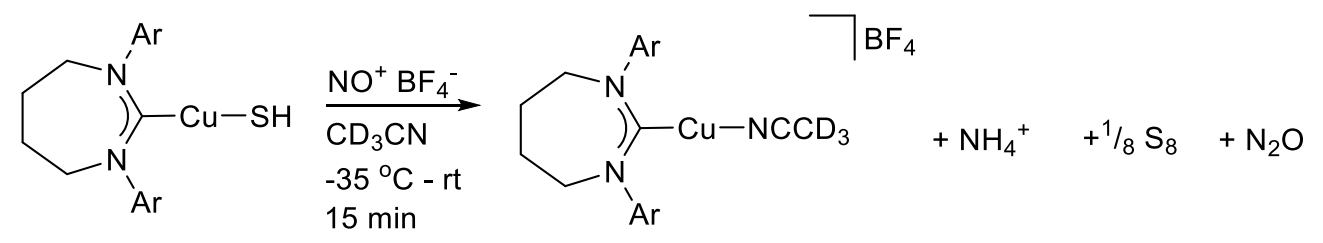

$\mathrm{NO}^{+} \mathrm{BF}_{4}^{-}(0.007 \mathrm{~g}, 0.060 \mathrm{mmol})$ was added to a solution of 7DippCuSH $(0.030 \mathrm{~g}, 0.060 \mathrm{mmol})$

in $\mathrm{CD}_{3} \mathrm{CN}(1 \mathrm{~mL})$ at $-35^{\circ} \mathrm{C}$. The mixture was allowed to warm to room temperature with stirring before the ${ }^{1} \mathrm{H}$ NMR spectrum was recorded.

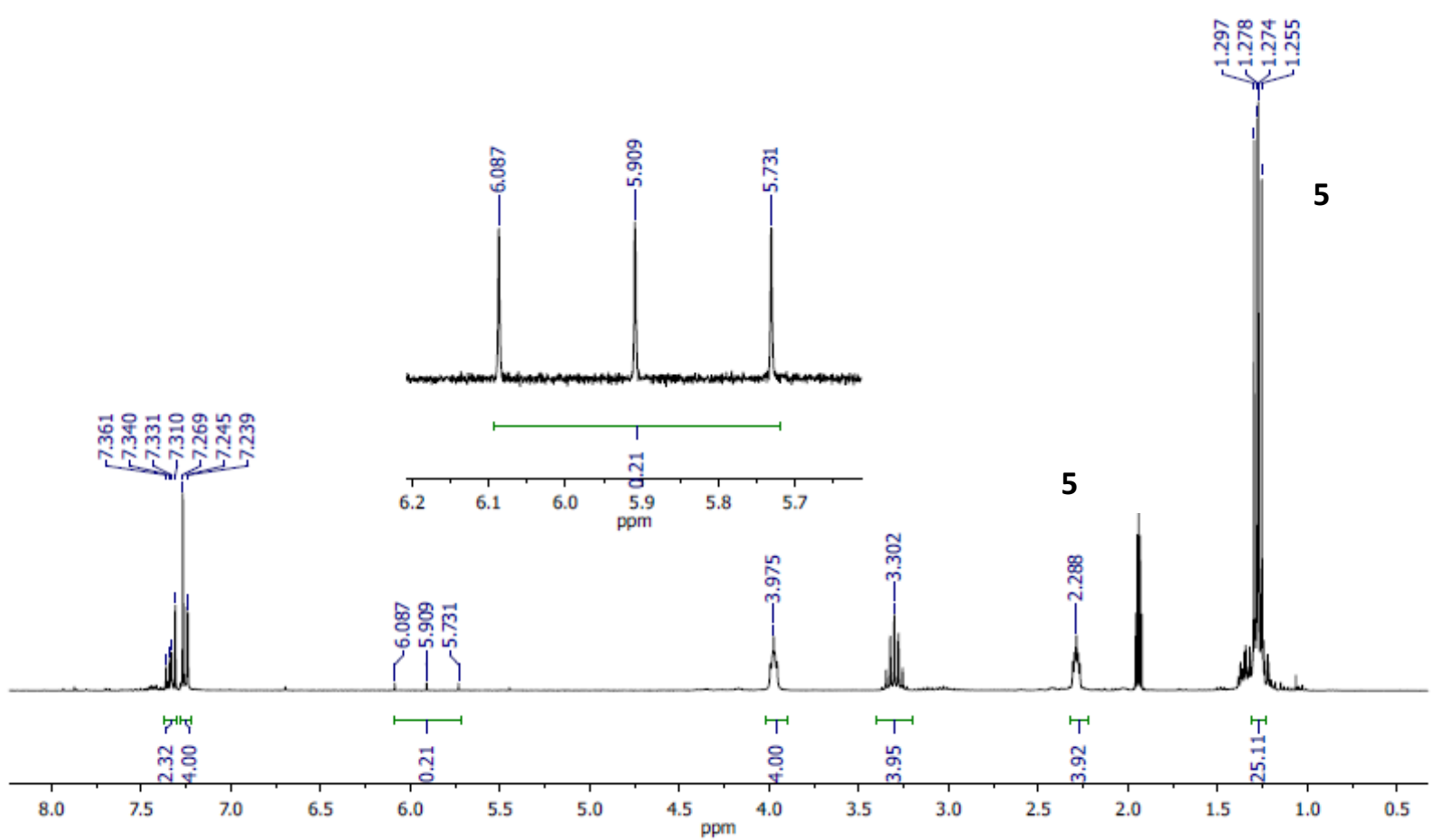

Figure S15. ${ }^{1} \mathrm{H}$ NMR spectrum following addition of $\mathrm{NO}^{+} \mathrm{BF}_{4}{ }^{-}$to $\mathbf{2}$, resulting in $\mathbf{5}$ in $\mathrm{CD}_{3} \mathrm{CN}$. 
Nitrosonium reactivity of $\mathbf{2}$ (cont'd)

Triphenylphosphine (0.016 g, $0.060 \mathrm{mmol})$ was added and the ${ }^{1} \mathrm{H}$ and ${ }^{31} \mathrm{P}$ NMR spectra were recorded after $15 \mathrm{~min}$.

Before addition of $\mathrm{PPh}_{3}$
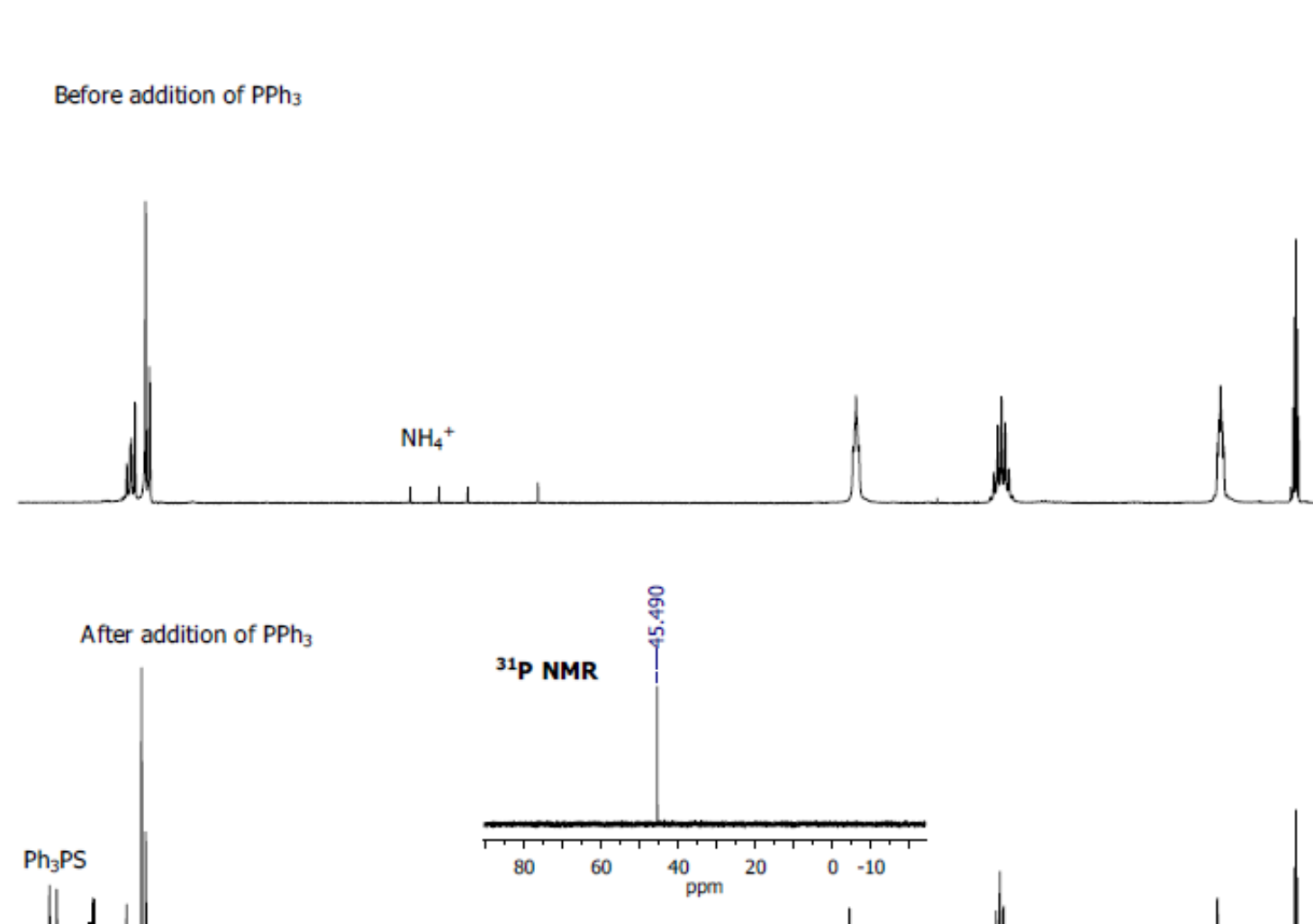

lwh

$\mathrm{NH}_{4}{ }^{+}$

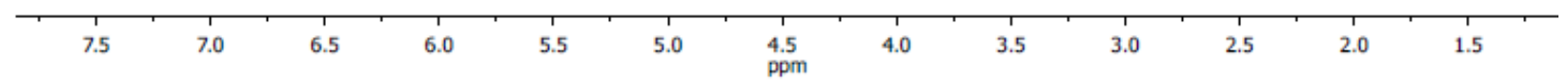

Figure S16. ${ }^{1} \mathrm{H}$ and ${ }^{31} \mathrm{P}$ spectrum following addition of $\mathrm{Ph}_{3} \mathrm{P}$ in $\mathrm{CD}_{3} \mathrm{CN}$. 
GC-MS detection of $\mathrm{N}_{2} \mathrm{O}$.

Selected ion recording (SIR) of $m / z 44\left(\mathrm{~N}_{2} \mathrm{O}\right)$ was performed on a $50 \mu \mathrm{L}$ sample of the reaction headspace. As a control set up, to rule out $\mathrm{CO}_{2}(\mathrm{~m} / \mathrm{z} 44)$, SIR was also performed on a $50 \mu \mathrm{L}$ sample of the headspace of a vial prepared in the glovebox with just solvent added. The headspace analysis of a reaction of $\mathrm{NO}^{+}(0.007 \mathrm{~g}, 0.06 \mathrm{mmol})$ with $7 \mathrm{DippCuSH}(0.030 \mathrm{~g}, 0.060 \mathrm{mmol})$ showed an integration of the $m / z 44$ peak to be 15 times that of the headspace analysis of the control set up.

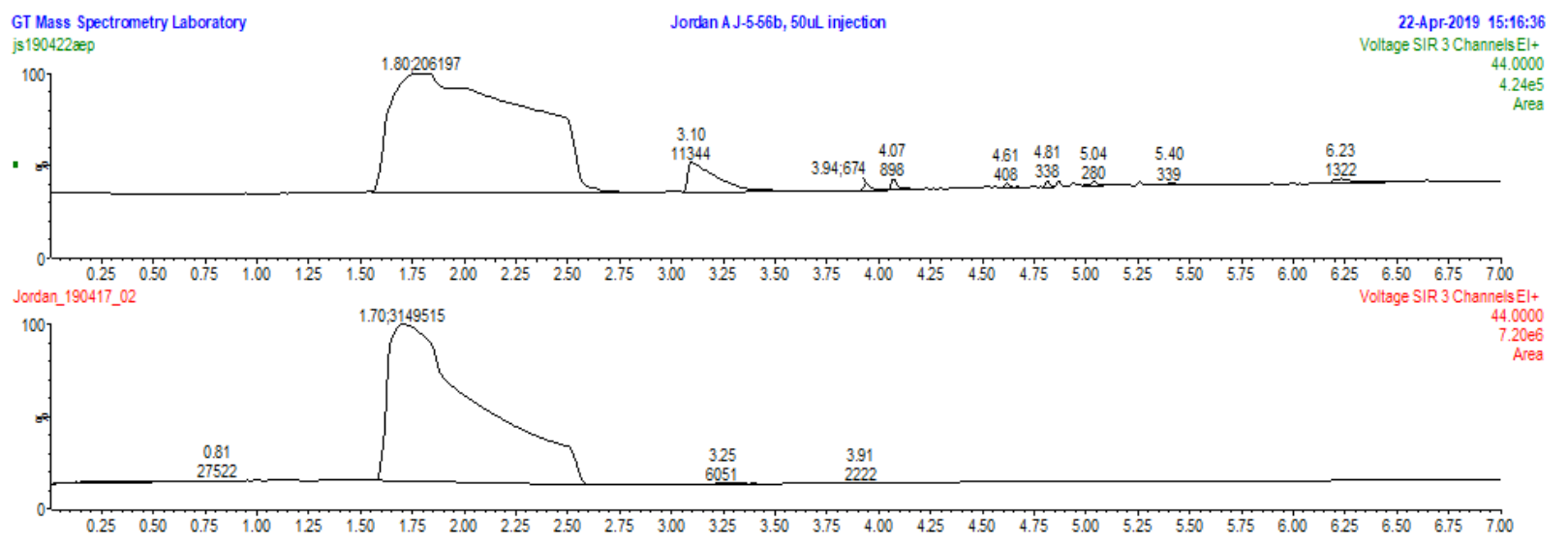

Figure S17. GC-MS SIR headspace analysis of the control set up (top) and the reaction of 7DippCuSH with $\mathrm{NO}^{+}$(bottom). 
Nitrosonium Reactivity of $\mathbf{1}$

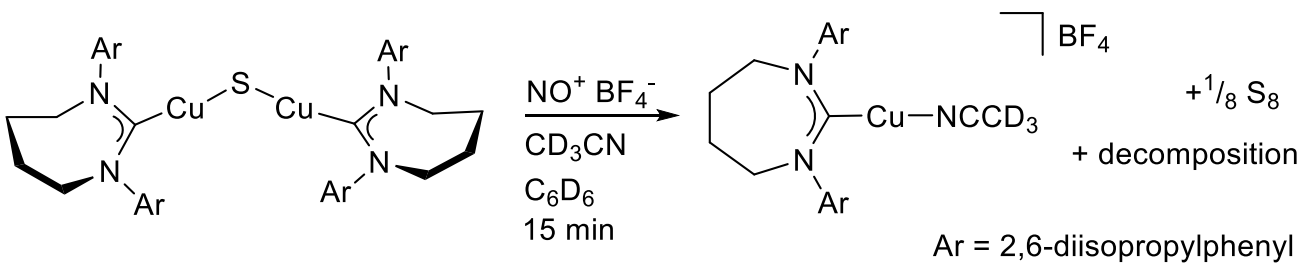

$\mathrm{NO}^{+} \mathrm{BF}_{4}^{-}(0.003 \mathrm{~g}, 0.026 \mathrm{mmol})$ was added to a solution of $(7 \mathrm{DippCu})_{2} \mathrm{~S}(0.025 \mathrm{~g}, 0.025 \mathrm{mmol})$ in $\mathrm{CD}_{3} \mathrm{CN}(0.5 \mathrm{~mL})$ and $\mathrm{C}_{6} \mathrm{D}_{6}(0.5 \mathrm{~mL})$ at room temperature. The mixture was allowed to stir for 15 min, filtered through celite to remove deposited $\mathrm{Cu}^{0}$, and concentrated in vacuo. The resulting solid was dried for $2 \mathrm{~h}$ under vacuum. $(0.015 \mathrm{~g}, 93 \%$ of $5+\mathrm{S})$. The solid was taken up in $\mathrm{CD}_{3} \mathrm{CN}$ (0.6 mL) before the $1 \mathrm{H}$ NMR spectrum was recorded.

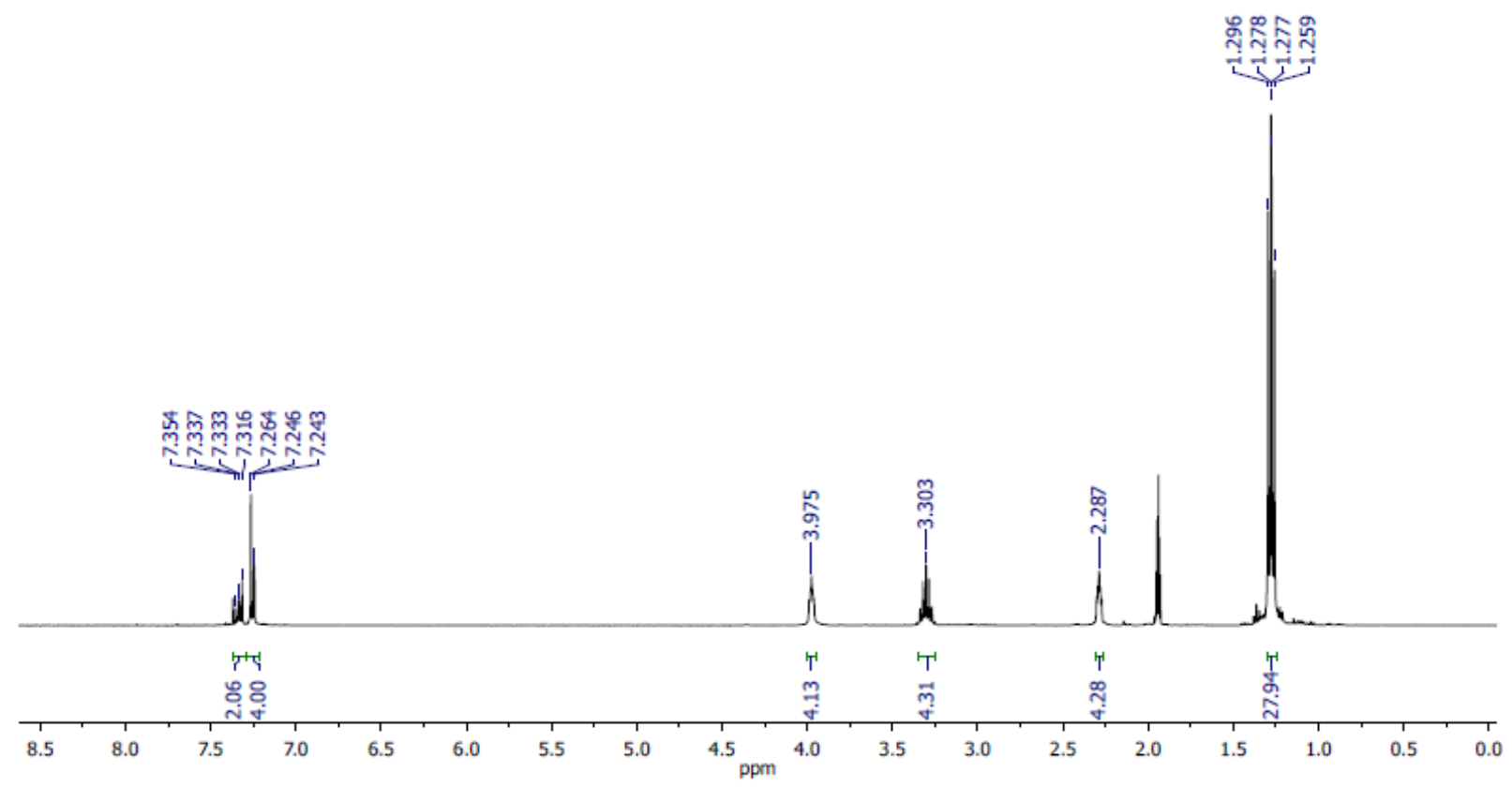

Figure S18. ${ }^{1} \mathrm{H}$ NMR spectrum of 1 in $\mathrm{CD}_{3} \mathrm{CN}$ after reaction with $\mathrm{NO}^{+} \mathrm{BF}_{4}^{-}$. 
Nitrosonium Reactivity of $\mathbf{1}$ (cont'd)

Triphenylphosphine $(0.013 \mathrm{~g}, 0.050 \mathrm{mmol})$ was then added, and the solution was reanalyzed by NMR spectroscopy.

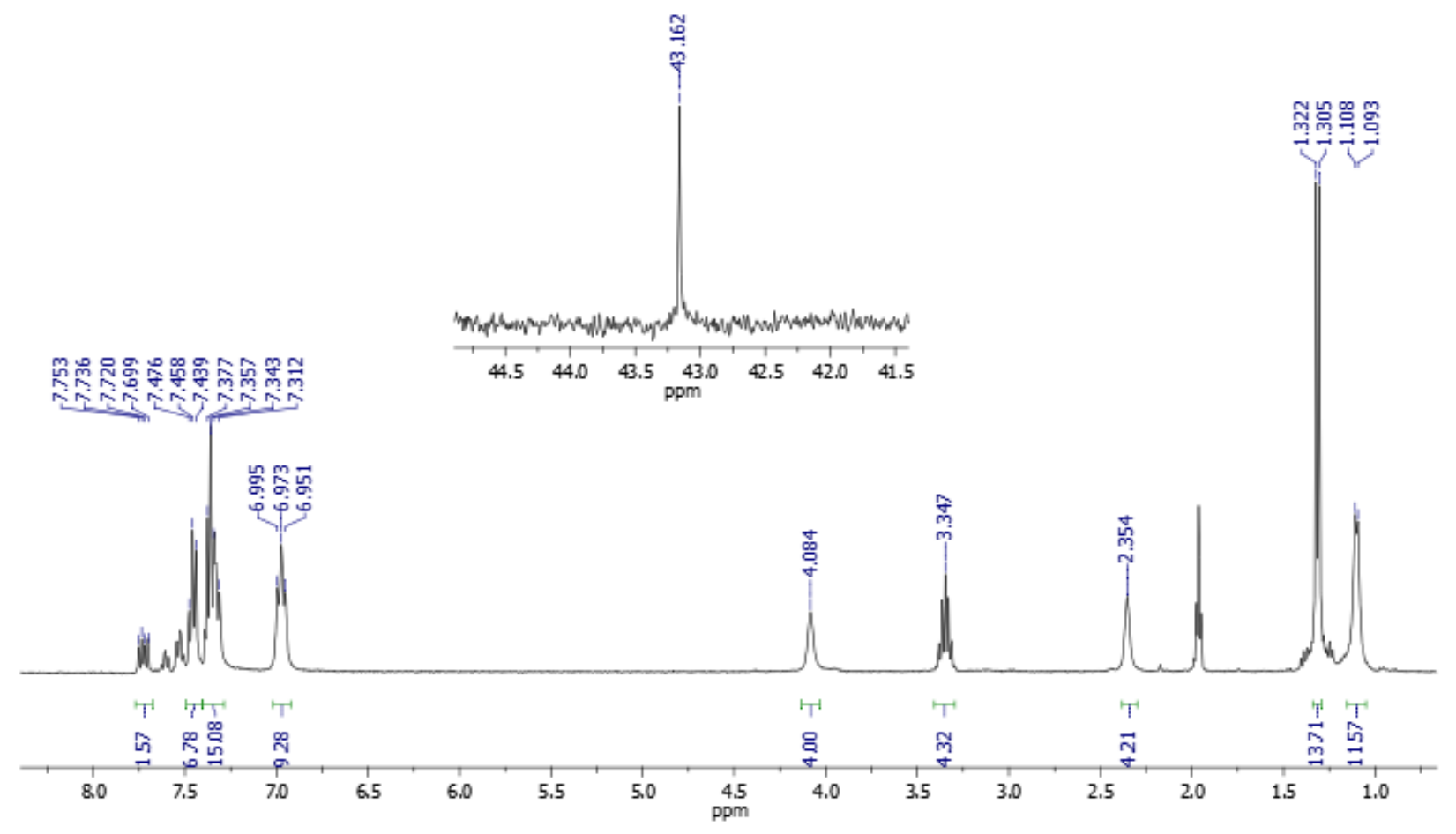

Figure S19. ${ }^{1} \mathrm{H}$ and ${ }^{31} \mathrm{P}$ NMR spectra following addition of $\mathrm{Ph}_{3} \mathrm{P}$, resulting in $\mathrm{Ph}_{3} \mathrm{P}=\mathrm{S}$ in $\mathrm{CD}_{3} \mathrm{CN}$. 
Nitrosonium Reactivity of $\mathbf{1}$ in $\mathrm{C}_{6} \mathrm{H}_{5} \mathrm{~F}$

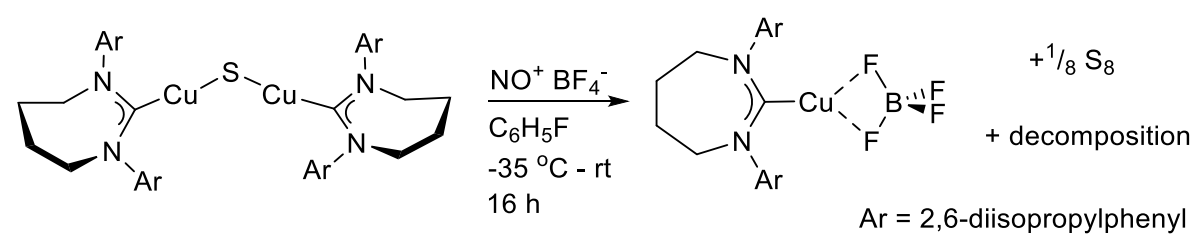

A solution of (7DippCu $)_{2} \mathrm{~S}(0.050 \mathrm{~g}, 0.050 \mathrm{mmol})$ in $\mathrm{C}_{6} \mathrm{H}_{5} \mathrm{~F}(2 \mathrm{~mL})$ was slowly added to solid $\mathrm{NO}^{+} \mathrm{BF}_{4}^{-}(0.006 \mathrm{~g}, 0.052 \mathrm{mmol})$ at $-40^{\circ} \mathrm{C}$. The mixture was allowed to stir at $-40{ }^{\circ} \mathrm{C}$ for $4 \mathrm{~h}$ before it was allowed to warm to room temperature while stirring for an additional $12 \mathrm{~h}$. The resulting mixture was filtered through Celite to remove the precipitate and concentrated in vacuo. The resulting colorless solid was taken up in $\mathrm{CD}_{2} \mathrm{Cl}_{2}$ and analyzed by NMR spectroscopy.
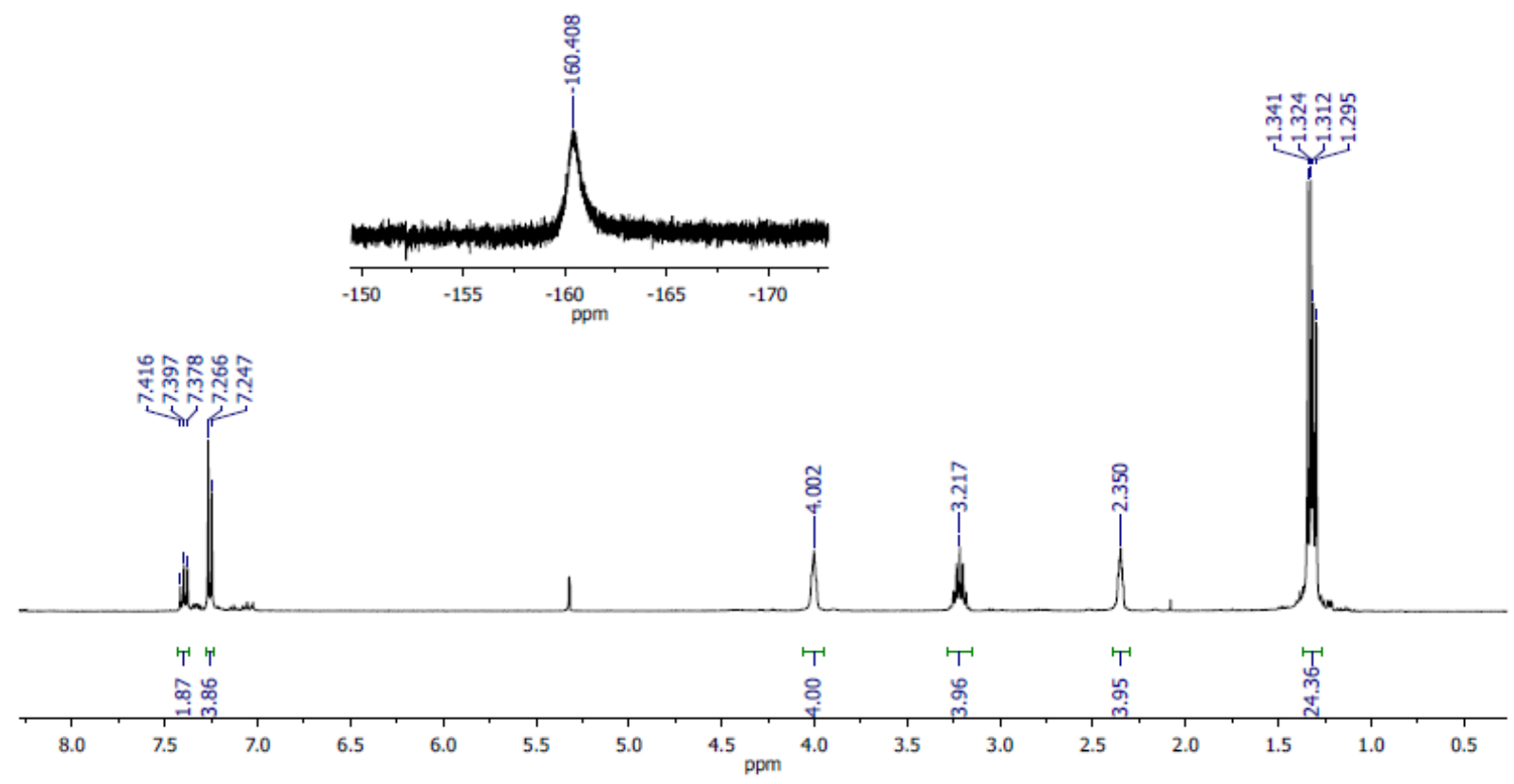

Figure S20. ${ }^{1} \mathrm{H}$ NMR spectrum of $\mathbf{1}$ after reaction with $\mathrm{NO}^{+} \mathrm{BF}_{4}^{-}$with ${ }^{19} \mathrm{~F}$ NMR spectra overlaid in $\mathrm{CD}_{2} \mathrm{Cl}_{2}$. 
Nitrosonium Reactivity of $\mathbf{1}$ in $\mathrm{C}_{6} \mathrm{H}_{5} \mathrm{~F}$ (cont'd)

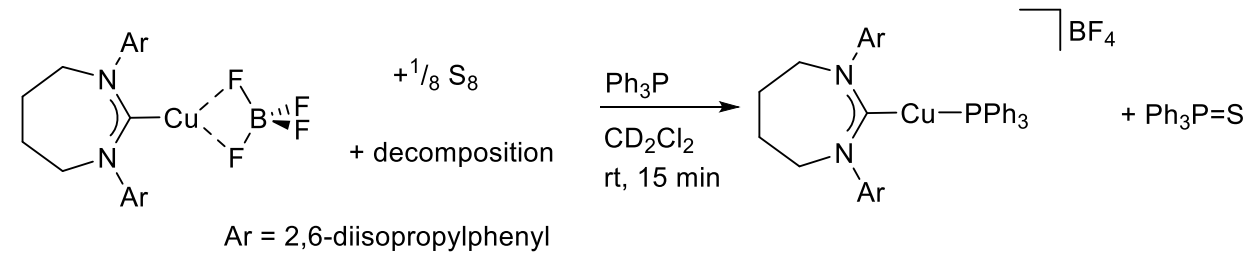

Triphenylphosphine $(0.026 \mathrm{~g}, 0.100 \mathrm{mmol})$ was then added, and the solution was reanalyzed by NMR spectroscopy.

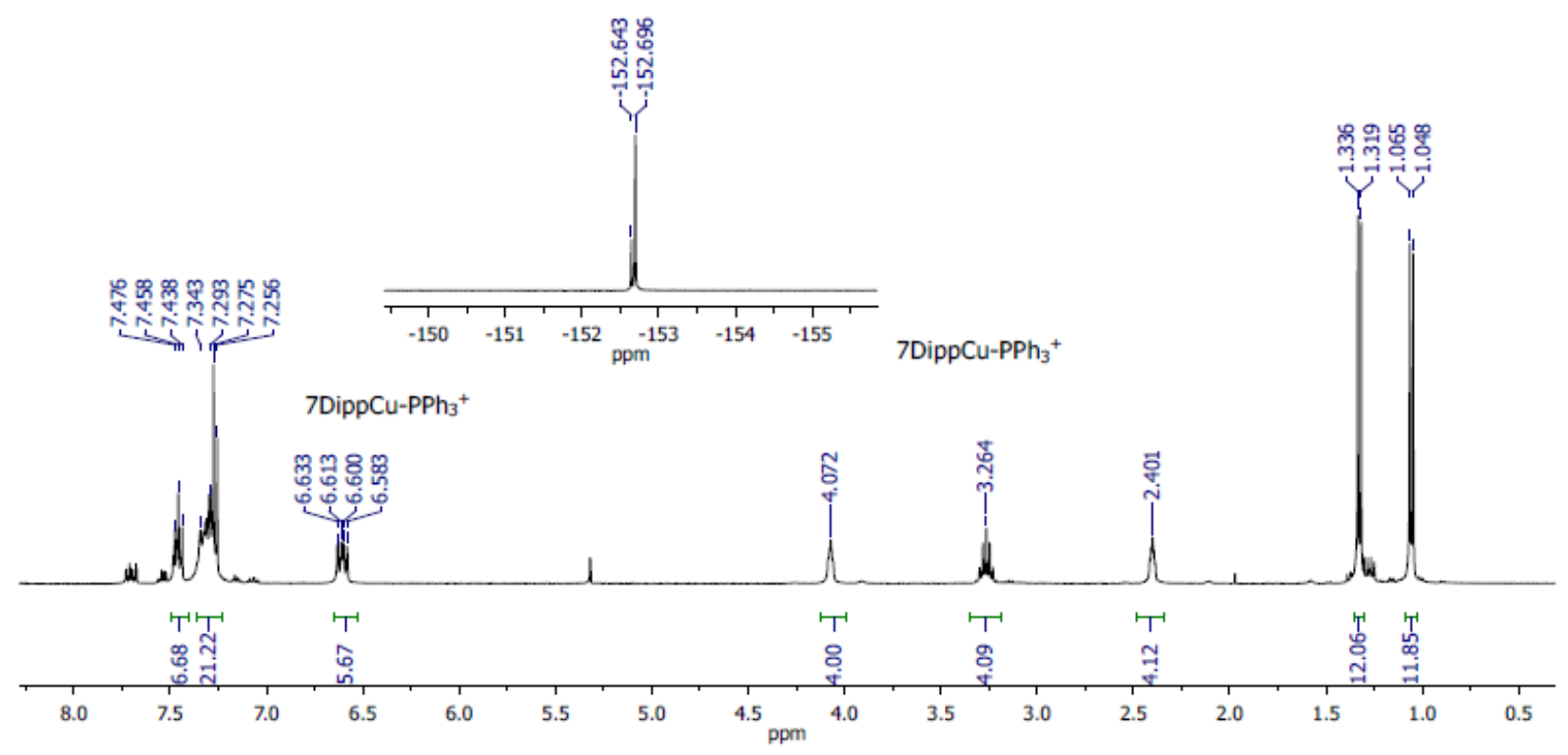

Figure S21. ${ }^{1} \mathrm{H}$ spectrum following addition of $\mathrm{PPh}_{3}$ with the ${ }^{19} \mathrm{~F}$ NMR spectrum overlaid in $\mathrm{CD}_{2} \mathrm{Cl}_{2}$.

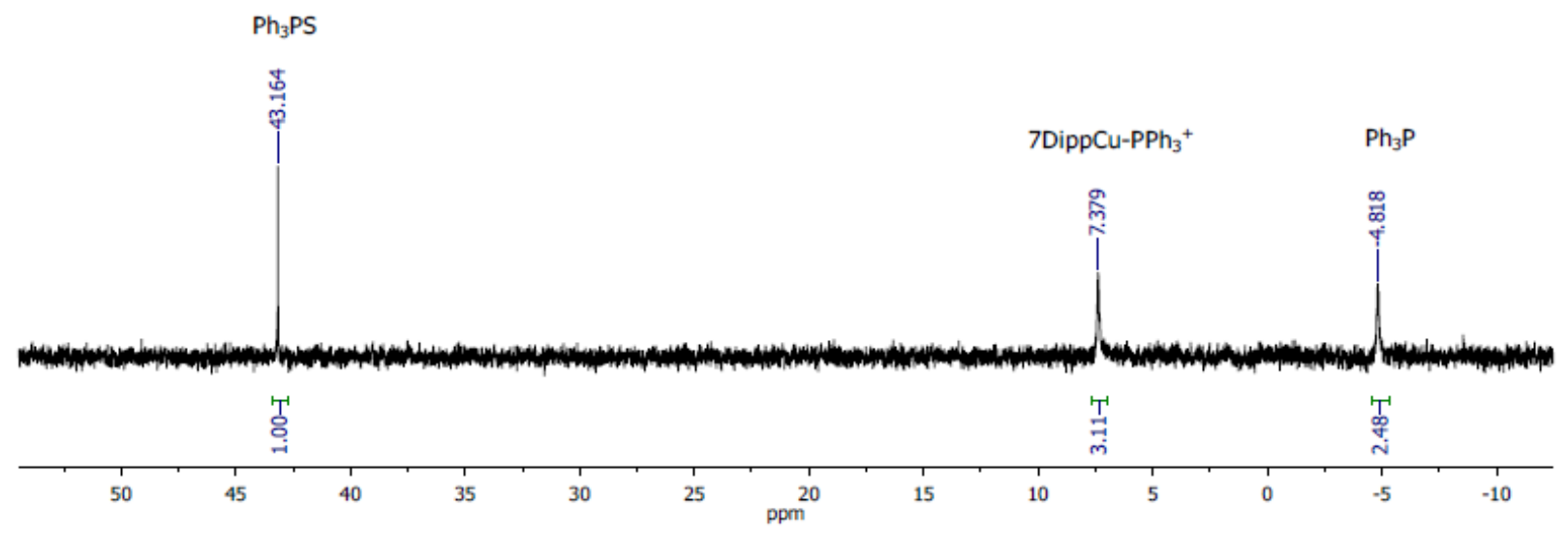

Figure S22. ${ }^{31} \mathrm{P}$ spectrum following addition of $\mathrm{PPh}_{3}$ in $\mathrm{CD}_{2} \mathrm{Cl}_{2}$. 
Nitrosonium Reactivity of $\mathbf{4}$

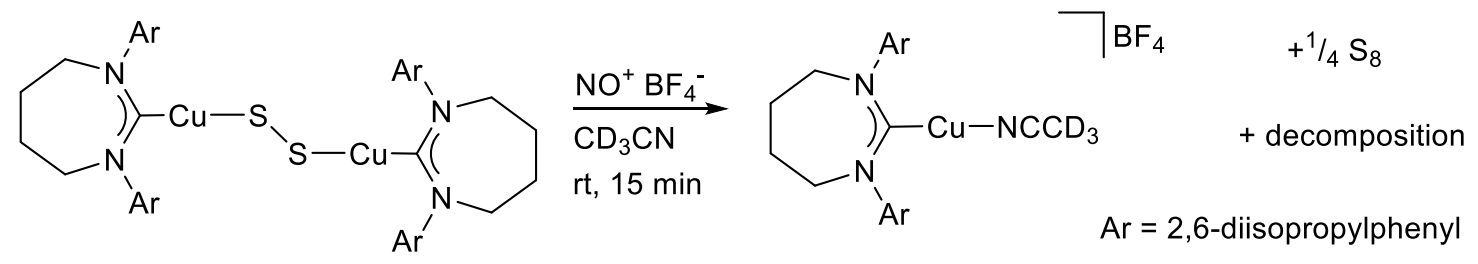

$\mathrm{NO}^{+} \mathrm{BF}_{4}^{-}(0.004 \mathrm{~g}, 0.034 \mathrm{mmol})$ was added to a solution of (7DippCuS $)_{2}(0.035 \mathrm{~g}, 0.034 \mathrm{mmol})$ in

$\mathrm{CD}_{3} \mathrm{CN}(1 \mathrm{~mL})$ at room temperature. The mixture was allowed to stir for 15 min before the ${ }^{1} \mathrm{H}$ NMR spectrum was recorded.

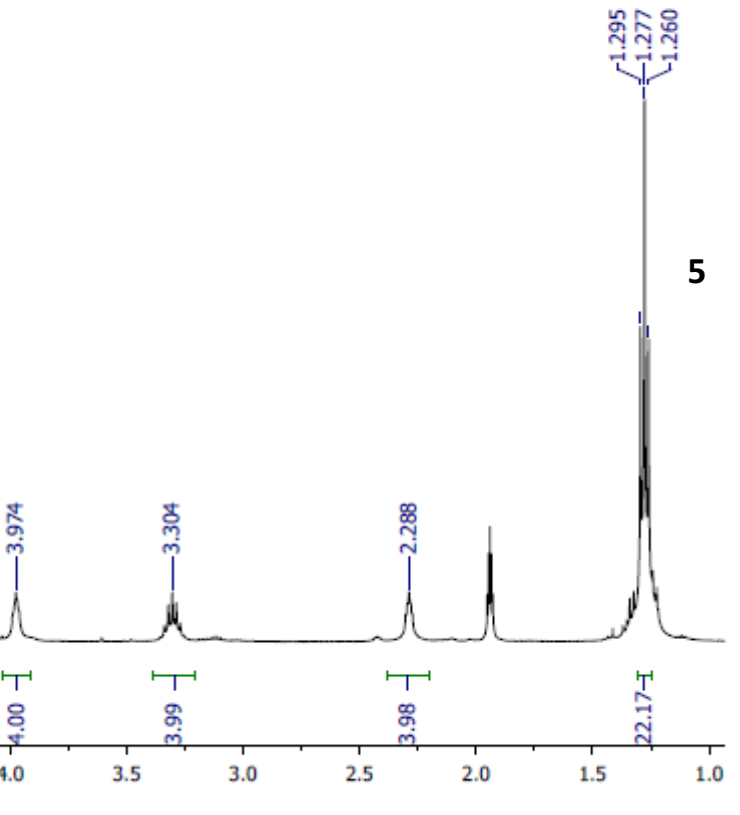

Figure S23. ${ }^{1} \mathrm{H}$ NMR spectrum following addition of $\mathrm{NO}^{+} \mathrm{BF}_{4}{ }^{-}$to 4 , resulting in 5 in $\mathrm{CD}_{3} \mathrm{CN}$. 
Nitrosonium Reactivity of 4 (cont'd)

Triphenylphosphine (0.026 g, $0.099 \mathrm{mmol})$ was added and the ${ }^{1} \mathrm{H}$ and ${ }^{31} \mathrm{P}$ NMR spectra were recorded after $15 \mathrm{~min}$.

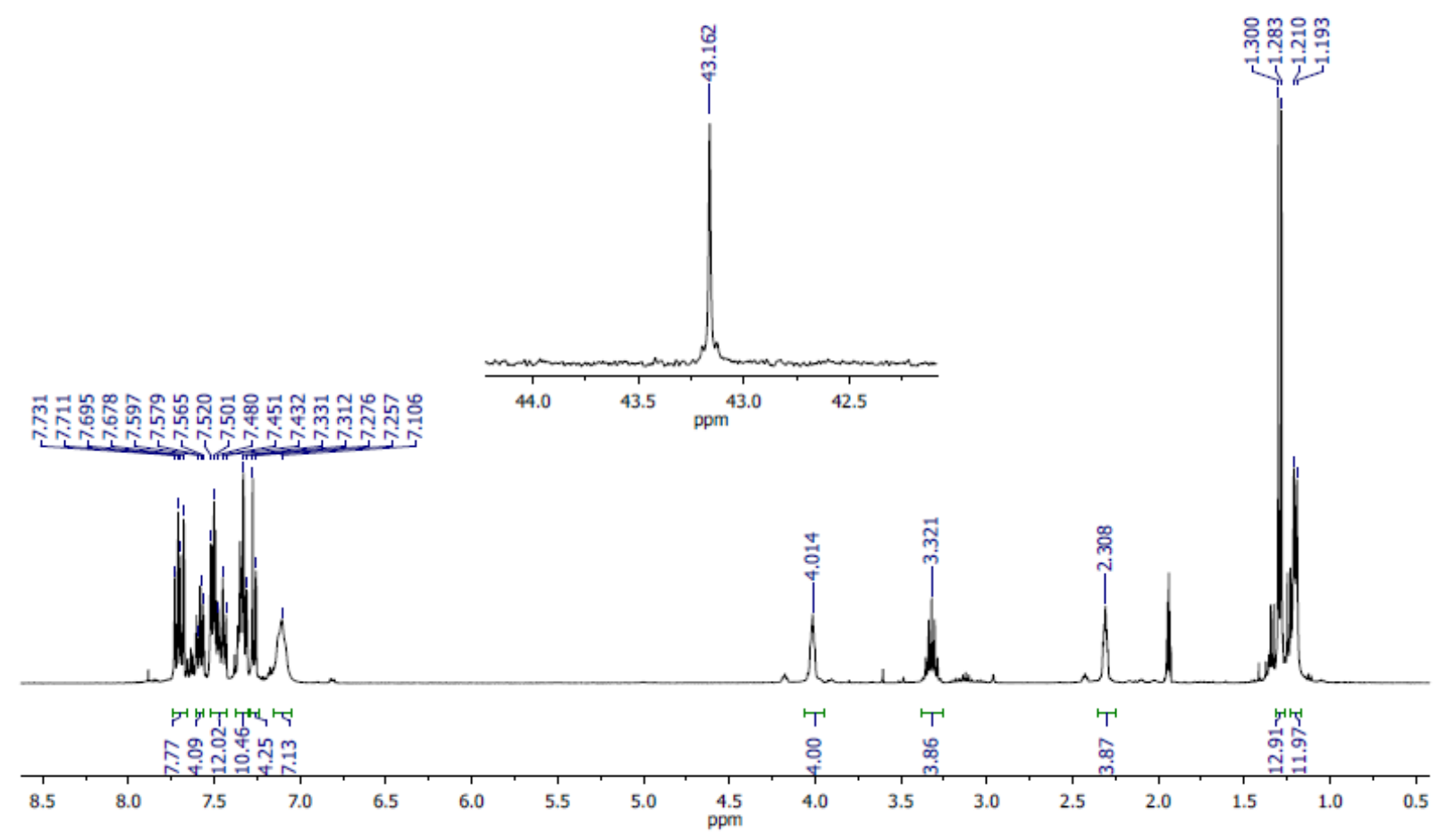

Figure S24. ${ }^{1} \mathrm{H}$ and ${ }^{31} \mathrm{P}$ NMR spectra following addition of $\mathrm{Ph}_{3} \mathrm{P}$, resulting in $\mathrm{Ph}_{3} \mathrm{P}=\mathrm{S}$ in $\mathrm{CD}_{3} \mathrm{CN}$. 
Generation of 7DippCuBF 4

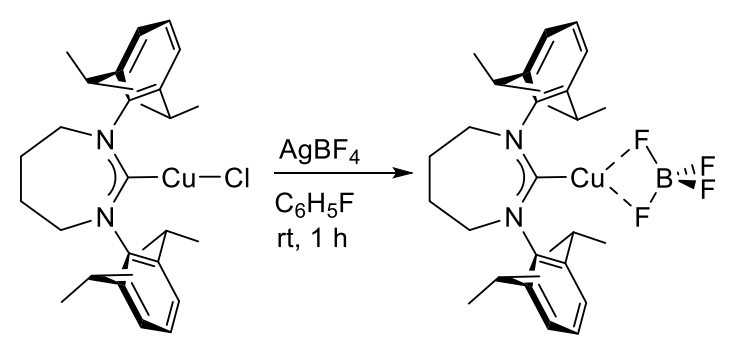

7DippCuBF 4 7DippCuCl (0.092 g, $0.18 \mathrm{mmol})$ and silver tetrafluoroborate $(0.035 \mathrm{~g}, 0.18 \mathrm{mmol})$ were combined in a 20 - $\mathrm{mL}$ vial, equipped with a stirbar, before $\mathrm{C}_{6} \mathrm{H}_{5} \mathrm{~F}(5 \mathrm{~mL})$ was added. The mixture was allowed to stir for $1 \mathrm{~h}$, filtered thought Celite, and concentrated in vacuo to afford the product as a colorless solid $(0.090 \mathrm{~g}, 89 \%) .{ }^{1} \mathrm{H}$ NMR $\left(400 \mathrm{MHz}, \mathrm{CD}_{2} \mathrm{Cl}_{2}\right): \delta(\mathrm{ppm}) 7.43\left(\mathrm{t},{ }^{3} \mathrm{JHH}_{\mathrm{HH}}=\right.$ $7.6 \mathrm{~Hz}, 2 \mathrm{H}$, para-CH), $7.25\left(\mathrm{~d},{ }^{3} J_{\mathrm{HH}}=7.6 \mathrm{~Hz}, 4 \mathrm{H}\right.$, meta- $\left.\mathrm{CH}\right), 4.00\left(\mathrm{~m}, 4 \mathrm{H}, \mathrm{NCH}_{2}\right), 3.21$ (sept, ${ }^{3} J_{\mathrm{HH}}$ $\left.=6.8 \mathrm{~Hz}, 4 \mathrm{H}, \mathrm{CH}\left(\mathrm{CH}_{3}\right)_{2}\right), 2.35\left(\mathrm{~m}, 4 \mathrm{H}, \mathrm{NCH}_{2} \mathrm{CH}_{2}\right), 1.33\left(\mathrm{~d},{ }^{3} \mathrm{~J}_{\mathrm{HH}}=6.8 \mathrm{~Hz}, 12 \mathrm{H}, \mathrm{CH}_{2}\left(\mathrm{CH}_{3}\right)_{2}\right), 1.29$ $\left(\mathrm{d},{ }^{3} J_{\mathrm{HH}}=6.8 \mathrm{~Hz}, 12 \mathrm{H}, \mathrm{CH}_{2}\left(\mathrm{CH}_{3}\right)_{2}\right) \cdot{ }^{13} \mathrm{C}\left\{{ }^{1} \mathrm{H}\right\} \mathrm{NMR}\left(176 \mathrm{MHz} \mathrm{CD}_{2} \mathrm{Cl}_{2}\right): \delta$ (ppm) 145.4 (ortho-C), 144.3 (ipso-C), 129.6 (para-C), 125.4 (meta-C), $54.4\left(\mathrm{NCH}_{2}\right), 29.2\left(\mathrm{CH}\left(\mathrm{CH}_{3}\right)_{2}\right), 25.5\left(\mathrm{NCH}_{2} \mathrm{CH}_{2}\right)$, $24.8\left(\mathrm{CH}\left(\mathrm{CH}_{3}\right)_{2}\right) .{ }^{11} \mathrm{~B}$ NMR $\left(128 \mathrm{MHz}, \mathrm{CD}_{2} \mathrm{Cl}_{2}\right): \delta(\mathrm{ppm})-1.8\left(\right.$ br s, $\left.1 \mathrm{~B}, B \mathrm{~F}_{4}{ }^{-}\right) .{ }^{19} \mathrm{~F}$ NMR $(378$ $\left.\mathrm{MHz}, \mathrm{CD}_{2} \mathrm{Cl}_{2}\right): \delta(\mathrm{ppm})-161.9\left(\mathrm{br} \mathrm{s}, 4 \mathrm{~F}, \mathrm{BF}_{4}^{-}\right)$.

Note: The carbene- $C$ resonance could not be resolved despite prolonged acquisition time. We suggest the signal is broadened by coupling to the $\mathrm{BF}_{4}^{-}$. The complex is extremely air- and moisture-sensitive. A small amount of $\operatorname{HOBF}_{3}{ }^{-}(1: 1: 1: 1 \text { quartet, under } 5 \%)^{3}$ is typically observed in the ${ }^{19} \mathrm{~F}$ NMR spectrum (see below) but continues to grow in over time. In the solid-state, decomposition is observed within $24 \mathrm{~h}$ at room temperature while under an inert atmosphere. 


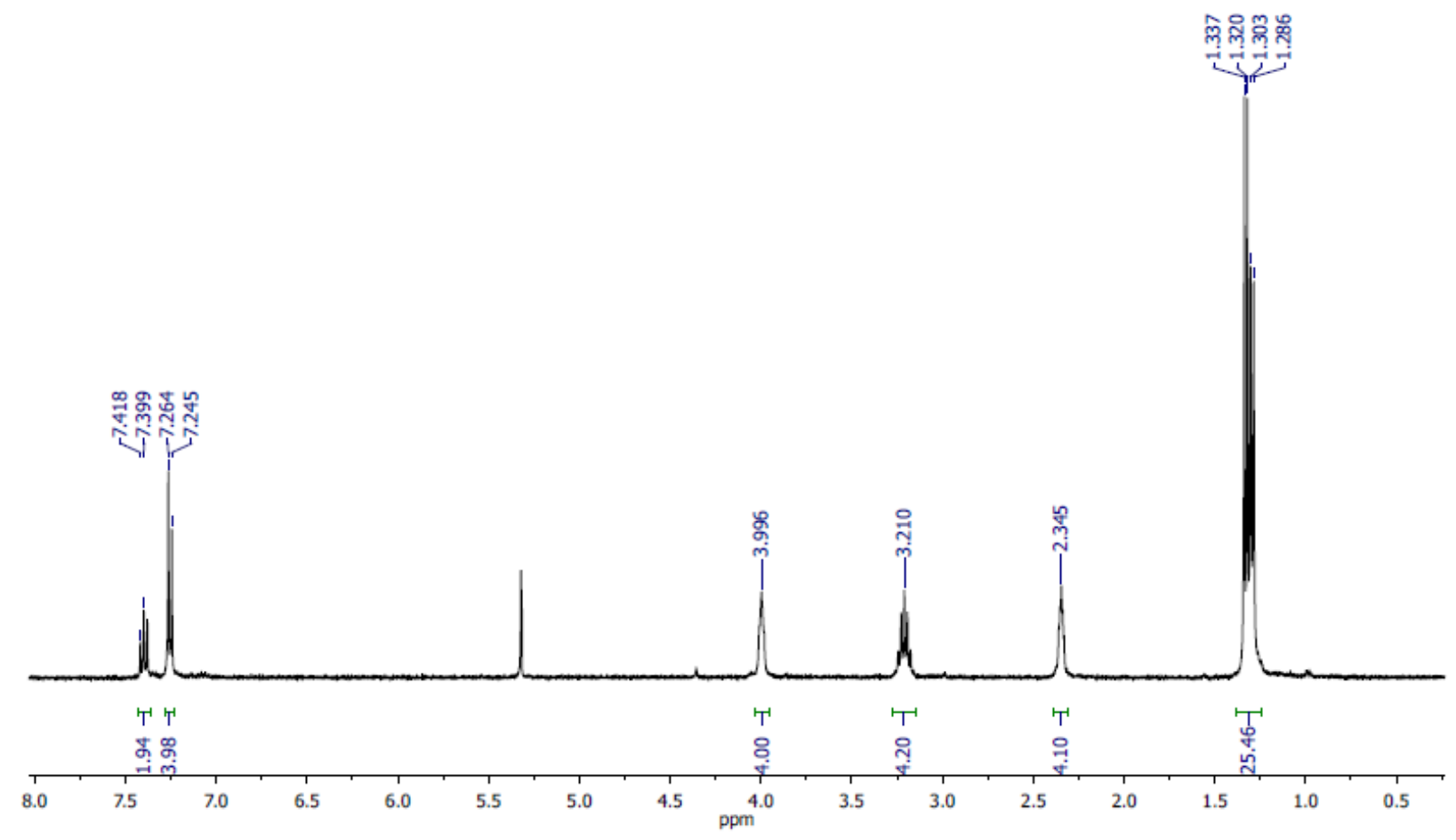

Figure S25. ${ }^{1} \mathrm{H}$ NMR spectrum of $7 \mathrm{DippCuBF}_{4}$ in $\mathrm{CD}_{2} \mathrm{Cl}_{2}$.

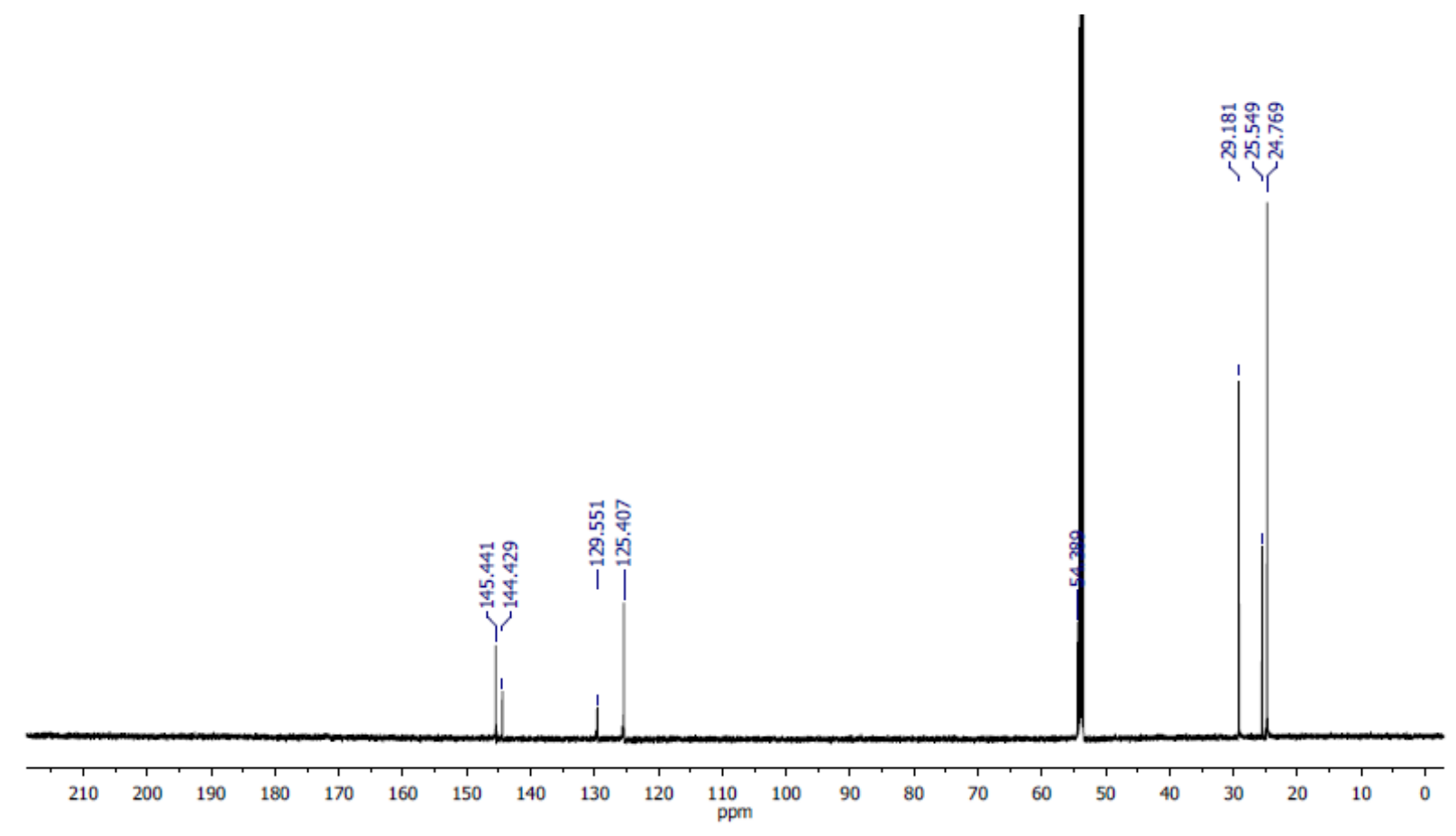

Figure S26. ${ }^{13} \mathrm{C}$ NMR spectrum of $7 \mathrm{DippCuBF}_{4}$ in $\mathrm{CD}_{2} \mathrm{Cl}_{2}$. 


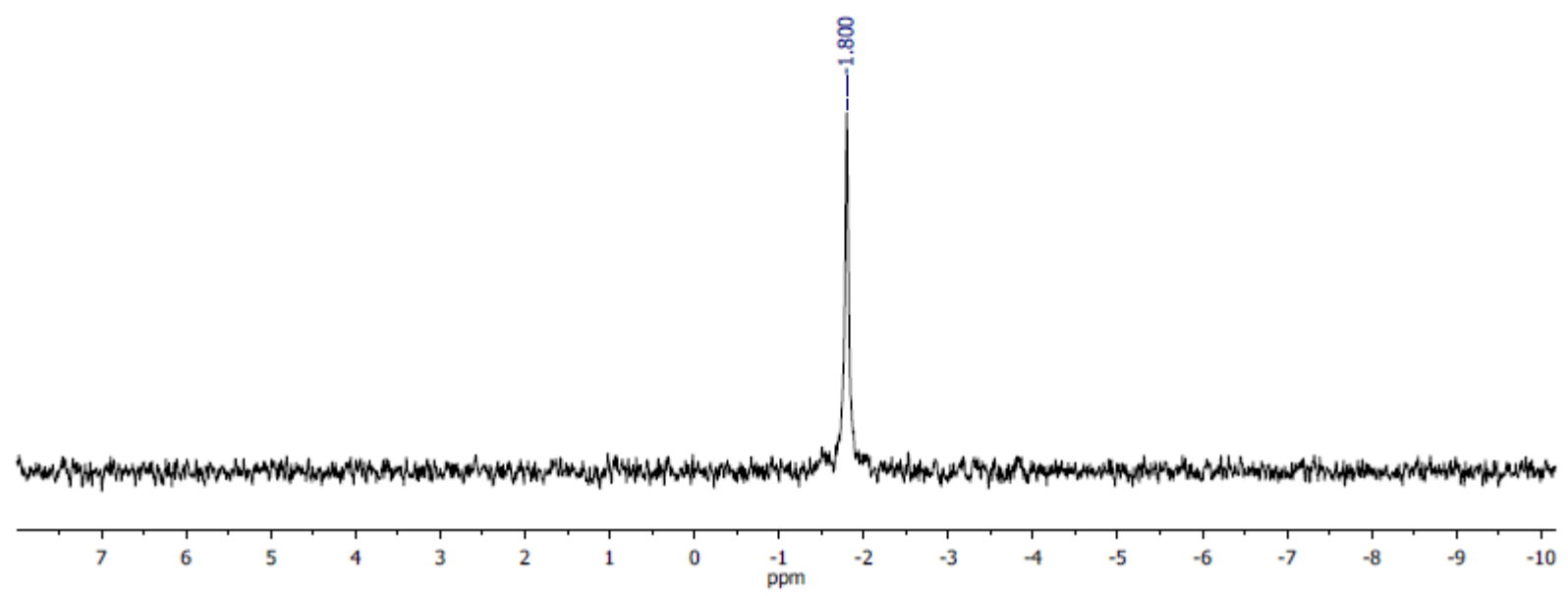

Figure S27. ${ }^{11} \mathrm{~B}$ NMR spectrum of $7 \mathrm{DippCuBF}_{4}$ in $\mathrm{CD}_{2} \mathrm{Cl}_{2}$.
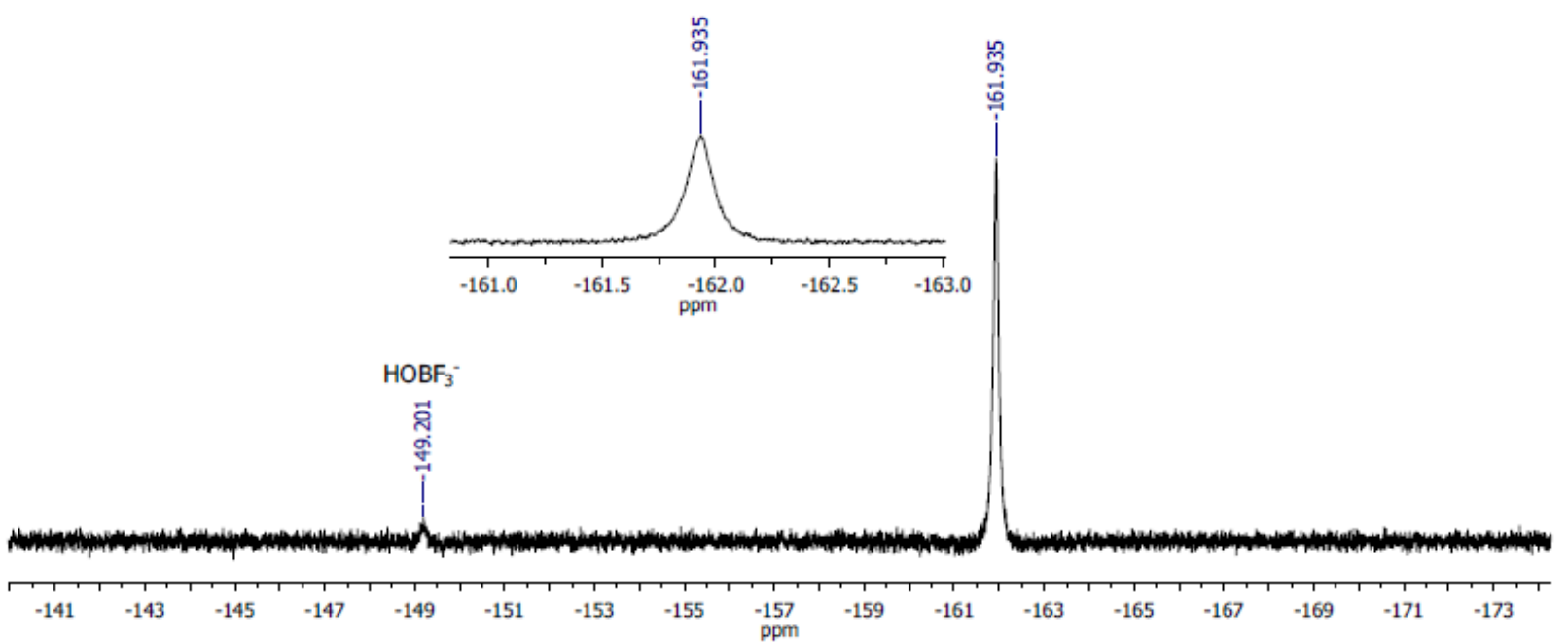

Figure S28. ${ }^{19} \mathrm{~F}$ NMR spectrum of $7 \mathrm{DippCuBF}_{4}$ in $\mathrm{CD}_{2} \mathrm{Cl}_{2}$. 
Nitrosonium Reactivity of (7DippCuH $)_{2}$

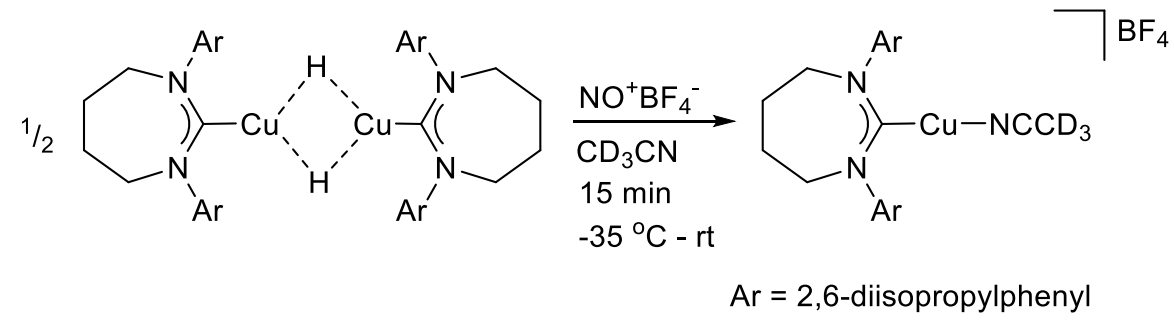

(7DippCuH $)_{2}(0.015 \mathrm{~g}, 0.016 \mathrm{mmol})$ and $\mathrm{NO}^{+} \mathrm{BF}_{4}^{-}(0.04 \mathrm{~g}, 0.034 \mathrm{mmol})$ were dissolved in $\mathrm{CD}_{3} \mathrm{CN}$ $(0.75 \mathrm{~mL})$ at $-35^{\circ} \mathrm{C}$ and mixed for $15 \mathrm{~min}$, then allowed to warm to room temperature, before the ${ }^{1} \mathrm{H}$ NMR spectrum was recorded.

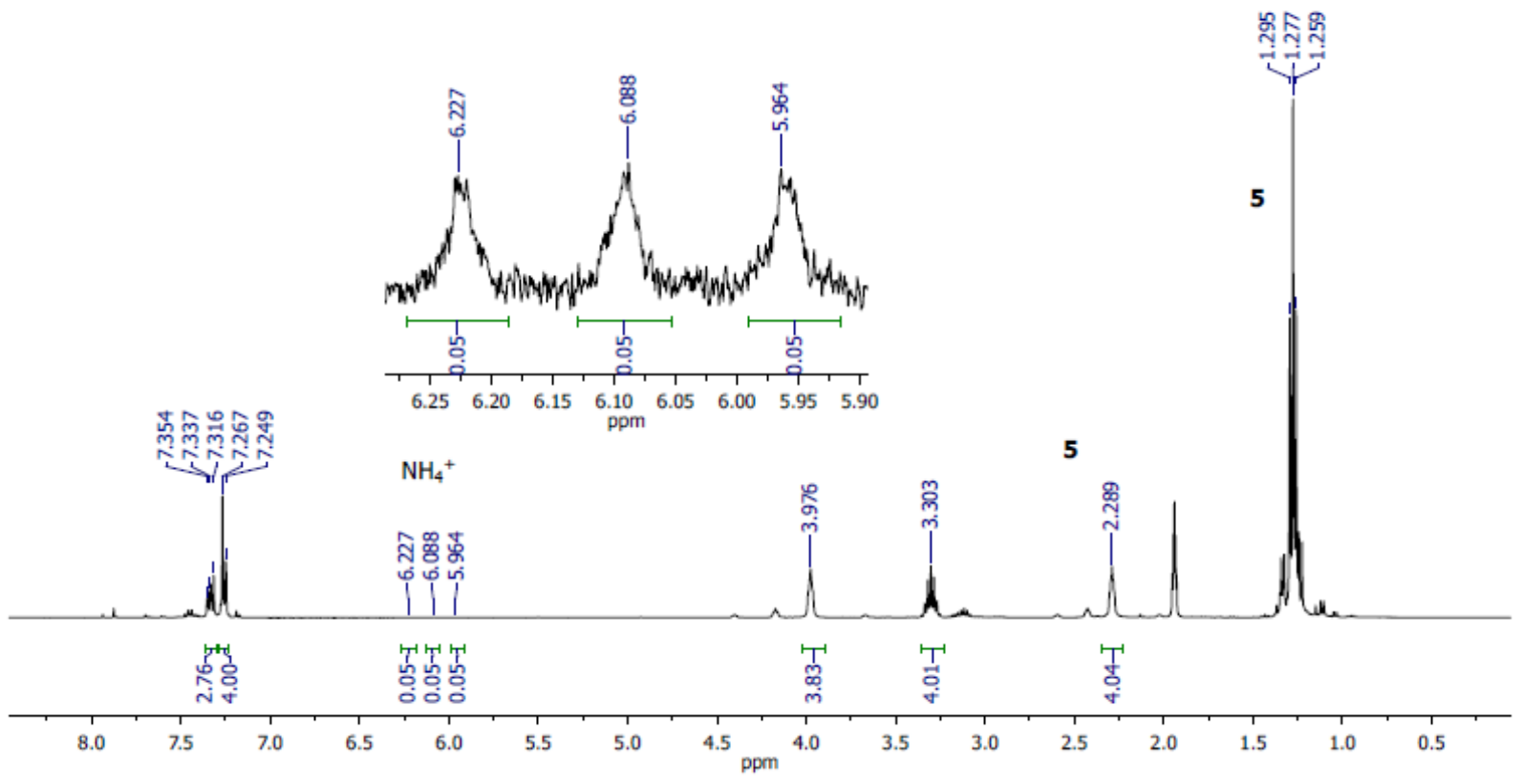

Figure S29. ${ }^{1} \mathrm{H}$ NMR spectrum following addition of $\mathrm{NO}^{+} \mathrm{BF}_{4}^{-}$to $(7 \mathrm{DippCuH})_{2}$. 
X-ray Diffraction Studies.

\section{Compound 1}

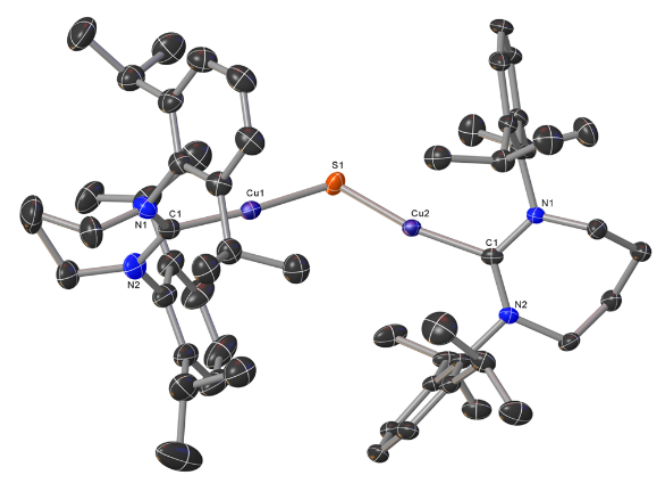

Experimental Single crystals of $\mathrm{C}_{188} \mathrm{H}_{273} \mathrm{Cu}_{6} \mathrm{~N}_{19} \mathrm{~S}_{3} \mathbf{1}$ were obtained from acetonitrile. A suitable crystal was selected, and the crystal was mounted on a loop with paratone oil on a Bruker D8 Venture diffractometer. The crystal was kept at $100(2) \mathrm{K}$ during data collection. Using Olex $2,{ }^{4}$ the structure was solved with the ShelXT ${ }^{5}$ structure solution program using Intrinsic Phasing and refined with the ShelXL ${ }^{6}$ refinement package using Least Squares minimization.

Crystal Data for $\mathrm{C}_{188} \mathrm{H}_{273} \mathrm{Cu}_{6} \mathrm{~N}_{19} \mathrm{~S}_{3}(M=3276.75 \mathrm{~g} / \mathrm{mol}$ ): monoclinic, space group P2/n (no. 13), $a=24.8277(13) \AA, b=12.3758(7) \AA, c=62.737(3) \AA, \beta=97.108(3)^{\circ}, V=19128.6(17) \AA^{3}, Z=$ 4, $T=100(2) \mathrm{K}, \mu(\mathrm{CuK} \alpha)=1.424 \mathrm{~mm}^{-1}$, Dcalc $=1.138 \mathrm{~g} / \mathrm{cm}^{3}, 142144$ reflections measured $\left(5.218^{\circ} \leq 2 \Theta \leq 130.166^{\circ}\right), 32605$ unique $\left(R_{\text {int }}=0.0744, R_{\text {sigma }}=0.0549\right)$ which were used in all calculations. The final $R_{1}$ was 0.0655 (I $\left.>2 \sigma(\mathrm{I})\right)$ and $w R_{2}$ was 0.1751 (all data). 
Table S1 Crystal data and structure refinement for 1.

Identification code

Empirical formula

Formula weight

Temperature/K

Crystal system

Space group

$\mathrm{a} / \AA$

$\mathrm{b} / \AA$

$\mathrm{c} / \AA$

$\alpha /^{\circ}$

$\beta /{ }^{\circ}$

$\gamma /{ }^{\circ}$

Volume $/ \AA^{3}$

Z

$\rho_{\text {calc } g / \mathrm{cm}^{3}}$

$\mu / \mathrm{mm}^{-1}$

$\mathrm{F}(000)$

Crystal size $/ \mathrm{mm}^{3}$

Radiation
$\mathrm{Cu} 2 \mathrm{~S} \mathrm{~L}$

$\mathrm{C}_{188} \mathrm{H}_{273} \mathrm{Cu}_{6} \mathrm{~N}_{19} \mathrm{~S}_{3}$

3276.75

100(2)

monoclinic

$\mathrm{P} 2 / \mathrm{n}$

24.8277(13)

$12.3758(7)$

$62.737(3)$

90

97.108(3)

90

19128.6(17)

4

1.138

1.424

7023.0

$0.257 \times 0.228 \times 0.146$

$\operatorname{CuK} \alpha(\lambda=1.54178)$

$2 \Theta$ range for data collection/ ${ }^{\circ} 5.218$ to 130.166

Index ranges

$-26 \leq \mathrm{h} \leq 29,-14 \leq \mathrm{k} \leq 14,-73 \leq 1 \leq 73$

Reflections collected

142144

Independent reflections

$32605\left[\mathrm{R}_{\text {int }}=0.0744, \mathrm{R}_{\text {sigma }}=0.0549\right]$

Data/restraints/parameters

$32605 / 2766 / 2000$

Goodness-of-fit on $\mathrm{F}^{2}$

1.027

Final $R$ indexes $[\mathrm{I}>=2 \sigma(\mathrm{I})] \quad \mathrm{R}_{1}=0.0655, \mathrm{wR}_{2}=0.1647$

Final $\mathrm{R}$ indexes [all data] $\quad \mathrm{R}_{1}=0.0828, \mathrm{wR}_{2}=0.1751$

Largest diff. peak/hole / e $\AA^{-3} 2.72 /-1.27$

Table S2 Bond Lengths ( $\AA$ ) for 1

\begin{tabular}{|c|c|c|c|c|c|}
\hline Atom & Atom & Length/Å & Atom & Atom & Length/Å \\
\hline $\mathrm{Cu} 1$ & $\mathrm{Cu} 2$ & $3.5816(7)$ & C27_10 & C29_10 & $1.530(3)$ \\
\hline $\mathrm{Cu} 1$ & $\mathrm{~S} 1$ & $2.1115(11)$ & N1_11 & C1_11 & $1.345(2)$ \\
\hline Cu1 & C1_8 & $1.912(3)$ & N1_11 & C2_11 & $1.479(2)$ \\
\hline $\mathrm{Cu} 2$ & $\mathrm{~S} 1$ & $2.1236(10)$ & N1_11 & C6_11 & $1.453(2)$ \\
\hline $\mathrm{Cu} 2$ & C1_9 & $1.916(2)$ & N2_11 & C1_11 & $1.347(2)$ \\
\hline $\mathrm{Cu} 3$ & $\mathrm{Cu} 4$ & $3.4751(7)$ & N2_11 & C5_11 & $1.484(2)$ \\
\hline Cu3 & $\mathrm{S} 2$ & $2.1171(10)$ & N2_11 & C18_11 & $1.451(2)$ \\
\hline Cu3 & C1_10 & $1.909(2)$ & C2_11 & C3_11 & $1.513(3)$ \\
\hline $\mathrm{Cu} 4$ & $\mathrm{~S} 2$ & $2.1081(11)$ & C3_11 & C4_11 & $1.531(3)$ \\
\hline
\end{tabular}




\begin{tabular}{|c|c|c|c|c|}
\hline $\mathrm{Cu} 4$ & C1_11 & $1.892(3)$ & C4_11 C5_11 & $1.520(3)$ \\
\hline $\mathrm{Cu} 5$ & $\mathrm{Cu}^{1}$ & $3.5959(10)$ & C6_11 C7_11 & $1.398(3)$ \\
\hline $\mathrm{Cu} 5$ & S3 & $2.1128(10)$ & C6_11 C11_11 & $1.404(2)$ \\
\hline $\mathrm{Cu} 5$ & C1_13 & $1.900(2)$ & C7_11 C8_11 & $1.393(3)$ \\
\hline $\mathrm{Cu} 6$ & $\mathrm{Cu}^{2}$ & $3.6774(11)$ & C7_11 C12_11 & $1.522(3)$ \\
\hline Cu6 & S4 & $2.1159(10)$ & C8_11 C9_11 & $1.394(3)$ \\
\hline $\mathrm{Cu} 6$ & C1_12 & $1.904(2)$ & C9_11 C10_11 & $1.374(3)$ \\
\hline N1_8 & C1_8 & $1.344(2)$ & C10_11C11_11 & $1.393(3)$ \\
\hline N1_8 & $\mathrm{C} 2 \_8$ & $1.479(2)$ & C11_11C15_11 & $1.519(3)$ \\
\hline N1_8 & C6_8 & $1.454(2)$ & C12_11C13_11 & $1.532(3)$ \\
\hline N2_8 & C1_8 & $1.350(2)$ & C12_11C14_11 & $1.530(3)$ \\
\hline N2_8 & C5_8 & $1.485(2)$ & C15_11C16_11 & $1.526(3)$ \\
\hline N2_8 & C18_8 & $1.451(2)$ & C15_11C17_11 & $1.542(3)$ \\
\hline C2_8 & C3_8 & $1.512(3)$ & C18_11C19_11 & $1.398(2)$ \\
\hline C3_8 & C4_8 & $1.531(3)$ & C18_11C23_11 & $1.401(2)$ \\
\hline C4_8 & C5_8 & $1.519(3)$ & C19_11C20_11 & $1.401(3)$ \\
\hline C6_8 & C7_8 & $1.398(3)$ & C19_11C24_11 & $1.516(2)$ \\
\hline C6_8 & C11_8 & $1.404(2)$ & C20_11C21_11 & $1.384(3)$ \\
\hline C7_8 & C8_8 & $1.394(3)$ & C21_11C22_11 & $1.385(3)$ \\
\hline C7_8 & C12_8 & $1.521(3)$ & C22_11C23_11 & $1.395(3)$ \\
\hline C8_8 & C9_8 & $1.393(3)$ & C23_11C27_11 & $1.527(3)$ \\
\hline C9_8 & C10_8 & $1.374(3)$ & C24_11C25_11 & $1.528(3)$ \\
\hline C10_8 & C11_8 & $1.393(3)$ & C24_11C26_11 & $1.534(3)$ \\
\hline C11_8 & C15_8 & $1.519(3)$ & C27_11C28_11 & $1.527(3)$ \\
\hline C12_8 & C13_8 & $1.532(3)$ & C27_11C29_11 & $1.528(3)$ \\
\hline C12_8 & C14_8 & $1.530(3)$ & N1_12 C1_12 & $1.344(2)$ \\
\hline C15_8 & C16_8 & $1.527(3)$ & N1_12 C2_12 & $1.476(2)$ \\
\hline C15_8 & C17_8 & $1.541(3)$ & N1_12 C6_12 & $1.456(2)$ \\
\hline C18_8 & C19_8 & $1.398(3)$ & N2_12 C1_12 & $1.348(2)$ \\
\hline C18_8 & C23_8 & $1.400(2)$ & N2_12 C5_12 & $1.486(2)$ \\
\hline C19_8 & C20_8 & $1.401(3)$ & N2_12 C18_12 & $1.448(2)$ \\
\hline C19_8 & C24_8 & $1.518(2)$ & C2_12 C3_12 & $1.511(3)$ \\
\hline C20_8 & C21_8 & $1.383(3)$ & C3_12 C4_12 & $1.532(3)$ \\
\hline C21_8 & $\mathrm{C} 22 \_8$ & $1.385(3)$ & C4_12 C5_12 & $1.520(3)$ \\
\hline C22_8 & C23_8 & $1.395(3)$ & C6_12 C7_12 & $1.397(3)$ \\
\hline C23_8 & C27_8 & $1.527(3)$ & C6_12 C11_12 & $1.403(2)$ \\
\hline C24_8 & C25_8 & $1.529(3)$ & C7_12 C8_12 & $1.393(3)$ \\
\hline C24_8 & C26_8 & $1.534(3)$ & C7_12 C12_12 & $1.520(3)$ \\
\hline C27_8 & C28_8 & $1.530(3)$ & C8_12 C9_12 & $1.393(3)$ \\
\hline C27_8 & C29_8 & $1.531(3)$ & C9_12 C10_12 & $1.373(3)$ \\
\hline N1_9 & C1_9 & $1.346(2)$ & C10_12 C11_12 & $1.393(3)$ \\
\hline N1_9 & C2_9 & $1.481(2)$ & C11_12 C15_12 & $1.518(3)$ \\
\hline N1_9 & C6_9 & $1.454(2)$ & C12_12 C13_12 & $1.531(3)$ \\
\hline N2_9 & C1_9 & $1.349(2)$ & C12_12 C14_12 & $1.529(3)$ \\
\hline N2_9 & C5_9 & $1.484(2)$ & C15_12 C16_12 & $1.527(3)$ \\
\hline N2_9 & C18_9 & $1.452(2)$ & C15_12 C17_12 & $1.543(3)$ \\
\hline C2_9 & C3_9 & $1.514(3)$ & C18_12C19_12 & $1.400(3)$ \\
\hline C3_9 & C4_9 & $1.532(3)$ & C18_12 C23_12 & $1.400(2)$ \\
\hline C4_9 & C5_9 & $1.518(3)$ & C19_12 C20_12 & $1.401(3)$ \\
\hline
\end{tabular}




\begin{tabular}{|c|c|c|c|c|}
\hline C6_9 & C7_9 & $1.399(3)$ & C19_12 C24_12 & $1.517(3)$ \\
\hline C6_9 & C11_9 & $1.403(2)$ & C20_12 C21_12 & $1.383(3)$ \\
\hline C7_9 & C8_9 & $1.393(2)$ & C21_12 C22_12 & $1.385(3)$ \\
\hline C7_9 & C12_9 & $1.521(3)$ & C22_12 C23_12 & $1.396(3)$ \\
\hline C8_9 & C9_9 & $1.393(3)$ & C23_12 C27_12 & $1.527(3)$ \\
\hline C9_9 & C10_9 & $1.374(3)$ & C24_12 C25_12 & $1.529(3)$ \\
\hline C10_9 & C11_9 & $1.393(3)$ & C24_12 C26_12 & $1.534(3)$ \\
\hline C11_9 & C15_9 & $1.519(3)$ & C27_12 C28_12 & $1.529(3)$ \\
\hline C12_9 & C13_9 & $1.531(3)$ & C27_12 C29_12 & $1.532(3)$ \\
\hline C12_9 & C14_9 & $1.530(3)$ & N1_13 C1_13 & $1.344(2)$ \\
\hline C15_9 & C16_9 & $1.527(3)$ & N1_13 C2_13 & $1.479(2)$ \\
\hline C15_9 & C17_9 & $1.543(3)$ & N1_13 C6_13 & $1.453(2)$ \\
\hline C18_9 & C19_9 & $1.398(2)$ & N2_13 C1_13 & $1.349(2)$ \\
\hline C18_9 & C23_9 & $1.401(2)$ & N2_13 C5_13 & $1.484(2)$ \\
\hline C19_9 & C20_9 & $1.402(3)$ & N2_13 C18_13 & $1.450(2)$ \\
\hline C19_9 & C24_9 & $1.517(2)$ & C2_13 C3_13 & $1.512(3)$ \\
\hline C20_9 & C21_9 & $1.383(3)$ & C3_13 C4_13 & $1.531(3)$ \\
\hline C21_9 & C22_9 & $1.385(3)$ & C4_13 C5_13 & $1.518(3)$ \\
\hline C22_9 & C23_9 & $1.394(3)$ & C6_13 C7_13 & $1.399(3)$ \\
\hline C23_9 & C27_9 & $1.525(3)$ & C6_13 C11_13 & $1.404(2)$ \\
\hline C24_9 & C25_9 & $1.530(3)$ & C7_13 C8_13 & $1.394(3)$ \\
\hline C24_9 & C26_9 & $1.535(3)$ & C7_13 C12_13 & $1.520(3)$ \\
\hline C27_9 & C28_9 & $1.528(3)$ & C8_13 C9_13 & $1.393(3)$ \\
\hline C27_9 & C29_9 & $1.530(3)$ & C9_13 C10_13 & $1.374(3)$ \\
\hline N1_10 & C1_10 & $1.346(2)$ & C10_13 C11_13 & $1.393(3)$ \\
\hline N1_10 & C2_10 & $1.481(2)$ & C11_13 C15_13 & $1.520(3)$ \\
\hline N1_10 & C6_10 & $1.453(2)$ & C12_13 C13_13 & $1.533(3)$ \\
\hline N2_10 & C1_10 & $1.349(2)$ & C12_13 C14_13 & $1.531(3)$ \\
\hline N2_10 & C5_10 & $1.485(2)$ & C15_13 C16_13 & $1.527(3)$ \\
\hline N2_10 & C18_10 & $1.451(2)$ & C15_13 C17_13 & $1.543(3)$ \\
\hline C2_10 & C3_10 & $1.512(3)$ & C18_13 C19_13 & $1.397(3)$ \\
\hline C3_10 & C4_10 & $1.533(3)$ & C18_13 C23_13 & $1.401(2)$ \\
\hline C4_10 & C5_10 & $1.519(3)$ & C19_13 C20_13 & $1.402(3)$ \\
\hline C6_10 & C7_10 & $1.398(3)$ & C19_13 C24_13 & $1.517(3)$ \\
\hline C6_10 & C11_10 & $1.403(2)$ & C20_13 C21_13 & $1.383(3)$ \\
\hline C7_10 & C8_10 & $1.393(3)$ & C21_13 C22_13 & $1.385(3)$ \\
\hline C7_10 & C12_10 & $1.521(3)$ & C22_13 C23_13 & $1.395(3)$ \\
\hline C8_10 & C9_10 & $1.394(3)$ & C23_13 C27_13 & $1.526(3)$ \\
\hline C9_10 & C10_10 & $1.374(3)$ & C24_13 C25_13 & $1.529(3)$ \\
\hline C10_10 & 0 C11_10 & $1.393(3)$ & C24_13 C26_13 & $1.536(3)$ \\
\hline C11_10 & 0 C15_10 & $1.519(3)$ & C27_13 C28_13 & $1.529(3)$ \\
\hline C12_10 & 0 C13_10 & $1.532(3)$ & C27_13 C29_13 & $1.530(3)$ \\
\hline C12_10 & 0 C14_10 & $1.529(3)$ & N1S_2 C2S_2 & $1.128(3)$ \\
\hline C15_10 & 0 C16_10 & $1.527(3)$ & C2S_2 C3S_2 & $1.440(3)$ \\
\hline C15_10 & 0 C17_10 & $1.542(3)$ & N1S_3 C2S_3 & $1.128(3)$ \\
\hline C18_10 & 0 C19_10 & $1.398(2)$ & C2S_3 C3S_3 & $1.441(3)$ \\
\hline C18_10 & 0 C23_10 & $1.399(2)$ & N1S_4 C2S_4 & $1.128(3)$ \\
\hline C19_10 & 0 C20_10 & $1.401(3)$ & C2S_4 C3S_4 & $1.440(3)$ \\
\hline C19_10 & 0 C24_10 & $1.517(2)$ & N1S_5 C2S_5 & $1.128(3)$ \\
\hline
\end{tabular}




$\begin{array}{lllll}\text { C20_10 C21_10 } & 1.383(3) & \text { C2S_5 } & \text { C3S_5 } & 1.440(3) \\ \text { C21_10 C22_10 } & 1.385(3) & \text { N1S_6 } & \text { C2S_6 } & 1.129(3) \\ \text { C22_10 C23_10 } & 1.396(3) & \text { C2S_6 } & \text { C3S_6 } & 1.439(3) \\ \text { C23_10 C27_10 } & 1.526(3) & \text { N1S_7 } & \text { C2S_7 } & 1.128(3) \\ \text { C24_10 C25_10 } & 1.529(3) & \text { C2S_7 } & \text { C3S_7 } & 1.441(3) \\ \text { C24_10 C26_10 } & 1.536(3) & \text { N1S_1 } & \text { C2S_1 } & 1.129(3) \\ \text { C27_10 C28_10 } & 1.528(3) & \text { C2S_1 } & \text { C3S_1 } & 1.441(3)\end{array}$

Table S3 Bond Angles (deg) for 1

\begin{tabular}{|c|c|c|c|c|c|c|c|}
\hline Atom & Atom & Atom & Angle/ ${ }^{\circ}$ & Atom & Atom & Atom & Angle/ $/^{\circ}$ \\
\hline$\overline{S 1}$ & $\mathrm{Cu} 1$ & $\mathrm{Cu} 2$ & $32.36(3)$ & C22_10 & C23_10 & C27_10 & $119.62(19)$ \\
\hline C1_8 & $\mathrm{Cu} 1$ & $\mathrm{Cu} 2$ & $154.64(10)$ & C19_10 & C24_10 & C25_10 & $111.8(2)$ \\
\hline C1_8 & $\mathrm{Cu} 1$ & S1 & $172.83(10)$ & C19_10 & C24_10 & C26_10 & $110.98(19)$ \\
\hline S1 & $\mathrm{Cu} 2$ & $\mathrm{Cu} 1$ & $32.15(3)$ & C25_10 & C24_10 & C26_10 & $109.8(2)$ \\
\hline C1_9 & $\mathrm{Cu} 2$ & $\mathrm{Cu} 1$ & $163.25(8)$ & C23_10 & C27_10 & C28_10 & $110.7(2)$ \\
\hline C1_9 & $\mathrm{Cu} 2$ & S1 & $164.29(9)$ & C23_10 & C27_10 & C29_10 & $111.8(2)$ \\
\hline S2 & $\mathrm{Cu} 3$ & $\mathrm{Cu} 4$ & $34.58(3)$ & C28_10 & C27_10 & C29_10 & $110.9(2)$ \\
\hline C1_10 & $\mathrm{Cu} 3$ & $\mathrm{Cu} 4$ & $161.23(8)$ & C1_11 & N1_11 & C2_11 & $125.3(2)$ \\
\hline C1_10 & $\mathrm{Cu} 3$ & S2 & $163.95(9)$ & C1_11 & N1_11 & C6_11 & $117.61(19)$ \\
\hline S2 & $\mathrm{Cu} 4$ & $\mathrm{Cu} 3$ & $34.75(3)$ & C6_11 & N1_11 & C2_11 & $115.60(19)$ \\
\hline C1_11 & $\mathrm{Cu} 4$ & $\mathrm{Cu} 3$ & $156.32(9)$ & C1_11 & N2_11 & C5_11 & $129.56(19)$ \\
\hline C1_11 & $\mathrm{Cu} 4$ & S2 & $168.61(10)$ & C1_11 & N2_11 & C18_11 & $117.00(19)$ \\
\hline S3 & Cu5 & $\mathrm{Cu} 5^{1}$ & $31.68(4)$ & C18_11 & N2_11 & C5_11 & $113.40(18)$ \\
\hline C1_13 & $\mathrm{Cu} 5$ & $\mathrm{Cu} 5^{1}$ & $160.01(9)$ & N1_11 & C1_11 & $\mathrm{Cu} 4$ & $119.86(16)$ \\
\hline C1_13 & $\mathrm{Cu} 5$ & S3 & $168.27(10)$ & N1_11 & C1_11 & N2_11 & $118.3(2)$ \\
\hline S4 & $\mathrm{Cu} 6$ & $\mathrm{Cu} 6^{2}$ & $29.66(4)$ & N2_11 & C1_11 & $\mathrm{Cu} 4$ & $121.62(17)$ \\
\hline C1_12 & $\mathrm{Cu} 6$ & $\mathrm{Cu} 6^{2}$ & $161.01(9)$ & N1_11 & C2_11 & C3_11 & $113.5(2)$ \\
\hline C1_12 & Cu6 & S4 & $168.98(11)$ & C2_11 & C3_11 & C4_11 & $111.4(2)$ \\
\hline $\mathrm{Cu} 1$ & $\mathrm{~S} 1$ & $\mathrm{Cu} 2$ & $115.49(4)$ & C5_11 & C4_11 & C3_11 & $112.1(2)$ \\
\hline $\mathrm{Cu} 4$ & S2 & $\mathrm{Cu} 3$ & $110.67(4)$ & N2_11 & C5_11 & C4_11 & $113.7(2)$ \\
\hline $\mathrm{Cu} 5^{1}$ & S3 & $\mathrm{Cu} 5$ & $116.63(8)$ & C7_11 & C6_11 & N1_11 & $118.69(18)$ \\
\hline $\mathrm{Cu} 6$ & S4 & $\mathrm{Cu} 6^{2}$ & $120.68(8)$ & C7_11 & C6_11 & C11_11 & $122.30(18)$ \\
\hline C1_8 & N1_8 & C2_8 & $125.7(2)$ & C11_11 & C6_11 & N1_11 & $118.99(19)$ \\
\hline C1_8 & N1_8 & C6_8 & $118.22(19)$ & C6_11 & C7_11 & C12_11 & $122.82(19)$ \\
\hline C6_8 & N1_8 & C2_8 & $115.26(19)$ & C8_11 & C7_11 & C6_11 & $117.73(19)$ \\
\hline C1_8 & N2_8 & C5_8 & 129.18(19) & C8_11 & C7_11 & C12_11 & $119.4(2)$ \\
\hline C1_8 & N2_8 & C18_8 & $116.62(19)$ & C7_11 & C8_11 & C9_11 & $120.8(2)$ \\
\hline C18_8 & N2_8 & C5_8 & $113.46(19)$ & C10_11 & C9_11 & C8_11 & $120.2(2)$ \\
\hline N1_8 & C1_8 & $\mathrm{Cu} 1$ & $122.19(16)$ & C9_11 & C10_11 & C11_11 & $121.2(2)$ \\
\hline N1_8 & C1_8 & N2_8 & $117.8(2)$ & C6_11 & C11_11 & C15_11 & $122.2(2)$ \\
\hline N2_8 & C1_8 & $\mathrm{Cu} 1$ & $120.01(16)$ & C10_11 & C11_11 & C6_11 & $117.7(2)$ \\
\hline N1_8 & C2_8 & C3_8 & $114.1(2)$ & C10_11 & C11_11 & C15_11 & $120.0(2)$ \\
\hline C2_8 & C3_8 & C4_8 & $111.2(2)$ & C7_11 & C12_11 & C13_11 & $112.0(2)$ \\
\hline C5_8 & C4_8 & C3_8 & $112.2(2)$ & C7_11 & C12_11 & C14_11 & $110.3(2)$ \\
\hline N2_8 & C5_8 & C4_8 & $114.6(2)$ & C14_11 & C12_11 & C13_11 & $110.5(2)$ \\
\hline C7_8 & C6_8 & N1_8 & $118.47(18)$ & C11_11 & C15_11 & C16_11 & $111.8(2)$ \\
\hline C7_8 & C6_8 & C11_8 & $122.28(18)$ & C11_11 & C15_11 & C17_11 & $110.9(2)$ \\
\hline C11_8 & C6_8 & N1_8 & $119.22(19)$ & C16_11 & C15_11 & C17_11 & $110.9(2)$ \\
\hline
\end{tabular}




\begin{tabular}{|c|c|c|c|c|c|c|c|}
\hline C6_8 & C7_8 & C12_8 & $122.29(19)$ & C19_11 & C18_11 & N2_11 & $119.24(18)$ \\
\hline C8_8 & C7_8 & C6_8 & $118.07(19)$ & C19_11 & C18_11 & C23_11 & $122.92(18)$ \\
\hline C8_8 & C7_8 & C12_8 & $119.6(2)$ & C23_11 & C18_11 & N2_11 & $117.77(19)$ \\
\hline C9_8 & C8_8 & C7_8 & $120.4(2)$ & C18_11 & C19_11 & C20_11 & $117.20(19)$ \\
\hline C10_8 & C9_8 & C8_8 & $120.3(2)$ & C18_11 & C19_11 & C24_11 & $122.94(19)$ \\
\hline C9_8 & C10_8 & C11_8 & $121.5(2)$ & C20_11 & C19_11 & C24_11 & $119.9(2)$ \\
\hline C6_8 & C11_8 & C15_8 & $122.5(2)$ & C21_11 & C20_11 & C19_11 & $120.8(2)$ \\
\hline C10_8 & C11_8 & C6_8 & $117.4(2)$ & C20_11 & C21_11 & C22_11 & $120.7(2)$ \\
\hline C10_8 & C11_8 & C15_8 & 120.1(2) & C21_11 & C22_11 & C23_11 & $120.5(2)$ \\
\hline C7_8 & C12_8 & C13_8 & $111.6(2)$ & C18_11 & C23_11 & C27_11 & $121.54(19)$ \\
\hline C7_8 & C12_8 & C14_8 & $110.5(2)$ & C22_11 & C23_11 & C18_11 & 117.71(19) \\
\hline C14_8 & C12_8 & C13_8 & $110.7(2)$ & C22_11 & C23_11 & C27_11 & $120.47(19)$ \\
\hline C11_8 & C15_8 & C16_8 & $111.5(2)$ & C19_11 & C24_11 & C25_11 & $112.5(2)$ \\
\hline C11_8 & C15_8 & C17_8 & $111.4(2)$ & C19_11 & C24_11 & C26_11 & $111.7(2)$ \\
\hline C16_8 & C15_8 & C17_8 & $111.0(2)$ & C25_11 & C24_11 & C26_11 & $110.0(2)$ \\
\hline C19_8 & C18_8 & N2_8 & $118.62(18)$ & C23_11 & C27_11 & C28_11 & $110.5(2)$ \\
\hline C19_8 & C18_8 & C23_8 & $122.69(19)$ & C23_11 & C27_11 & C29_11 & $112.3(2)$ \\
\hline C23_8 & C18_8 & N2_8 & $118.69(19)$ & C28_11 & C27_11 & C29_11 & $111.1(2)$ \\
\hline C18_8 & C19_8 & C20_8 & $117.57(19)$ & C1_12 & N1_12 & C2_12 & 128.63(18) \\
\hline C18_8 & C19_8 & C24_8 & $122.59(19)$ & C1_12 & N1_12 & C6_12 & $116.54(19)$ \\
\hline C20_8 & C19_8 & C24_8 & $119.8(2)$ & C6_12 & N1_12 & C2_12 & $114.64(18)$ \\
\hline C21_8 & C20_8 & C19_8 & $120.6(2)$ & C1_12 & N2_12 & C5_12 & $126.73(19)$ \\
\hline C20_8 & C21_8 & $\mathrm{C} 22 \_8$ & $120.6(2)$ & C1_12 & N2_12 & C18_12 & $118.43(19)$ \\
\hline C21_8 & C22_8 & C23_8 & $120.8(2)$ & C18_12 & N2_12 & C5_12 & $114.22(18)$ \\
\hline C18_8 & C23_8 & C27_8 & $121.8(2)$ & N1_12 & C1_12 & $\mathrm{Cu} 6$ & $120.95(15)$ \\
\hline C22_8 & C23_8 & C18_8 & $117.7(2)$ & N1_12 & C1_12 & N2_12 & 118.11(19) \\
\hline C22_8 & C23_8 & C27_8 & $120.3(2)$ & N2_12 & C1_12 & $\mathrm{Cu} 6$ & $120.90(16)$ \\
\hline C19_8 & C24_8 & C25_8 & $111.7(2)$ & N1_12 & C2_12 & C3_12 & $115.2(2)$ \\
\hline C19_8 & C24_8 & C26_8 & $111.6(2)$ & C2_12 & C3_12 & C4_12 & $111.6(2)$ \\
\hline C25_8 & C24_8 & C26_8 & $110.0(2)$ & C5_12 & C4_12 & C3_12 & $112.09(19)$ \\
\hline C23_8 & C27_8 & C28_8 & $111.3(2)$ & N2_12 & C5_12 & C4_12 & $113.6(2)$ \\
\hline C23_8 & C27_8 & C29_8 & $111.4(2)$ & C7_12 & C6_12 & N1_12 & $118.05(19)$ \\
\hline C28_8 & C27_8 & C29_8 & $110.0(2)$ & C7_12 & C6_12 & C11_12 & $122.73(18)$ \\
\hline C1_9 & N1_9 & C2_9 & $124.90(18)$ & C11_12 & C6_12 & N1_12 & $119.20(19)$ \\
\hline C1_9 & N1_9 & C6_9 & $118.38(18)$ & C6_12 & C7_12 & C12_12 & $122.21(19)$ \\
\hline C6_9 & N1_9 & C2_9 & $115.15(18)$ & C8_12 & C7_12 & C6_12 & $117.76(19)$ \\
\hline C1_9 & N2_9 & C5_9 & $129.36(18)$ & C8_12 & C7_12 & C12_12 & $120.0(2)$ \\
\hline C1_9 & N2_9 & C18_9 & $117.35(18)$ & C9_12 & C8_12 & C7_12 & $120.4(2)$ \\
\hline C18_9 & N2_9 & C5_9 & $113.23(17)$ & C10_12 & C9_12 & C8_12 & $120.6(2)$ \\
\hline N1_9 & C1_9 & $\mathrm{Cu} 2$ & $118.24(14)$ & C9_12 & C10_12 & C11_12 & $121.3(2)$ \\
\hline N1_9 & C1_9 & N2_9 & 117.74(19) & C6_12 & C11_12 & C15_12 & $122.73(19)$ \\
\hline N2_9 & C1_9 & $\mathrm{Cu} 2$ & $123.59(16)$ & C10_12 & C11_12 & C6_12 & $117.2(2)$ \\
\hline N1_9 & C2_9 & C3_9 & $113.5(2)$ & C10_12 & C11_12 & C15_12 & $120.0(2)$ \\
\hline C2_9 & C3_9 & C4_9 & $110.95(19)$ & C7_12 & C12_12 & C13_12 & $111.7(2)$ \\
\hline C5_9 & C4_9 & C3_9 & $112.4(2)$ & C7_12 & C12_12 & C14_12 & $110.4(2)$ \\
\hline N2_9 & C5_9 & C4_9 & 114.71(19) & C14_12 & C12_12 & C13_12 & $111.1(2)$ \\
\hline C7_9 & C6_9 & N1_9 & $118.22(18)$ & C11_12 & C15_12 & C16_12 & $111.5(2)$ \\
\hline C7_9 & C6_9 & C11_9 & $122.19(18)$ & C11_12 & C15_12 & C17_12 & $111.3(2)$ \\
\hline C11_9 & C6_9 & N1_9 & $119.50(18)$ & C16_12 & C15_12 & C17_12 & $110.5(2)$ \\
\hline
\end{tabular}




\begin{tabular}{|c|c|c|c|c|c|c|c|}
\hline C6_9 & C7_9 & C12_9 & $122.34(18)$ & C19_12 & C18_12 & N2_12 & $118.90(19)$ \\
\hline C8_9 & C7_9 & C6_9 & $118.05(19)$ & C23_12 & C18_12 & N2_12 & 118.63(19) \\
\hline C8_9 & C7_9 & C12_9 & 119.59(19) & C23_12 & C18_12 & C19_12 & $122.25(19)$ \\
\hline C9_9 & C8_9 & C7_9 & $120.5(2)$ & C18_12 & C19_12 & C20_12 & $117.6(2)$ \\
\hline C10_9 & C9_9 & C8_9 & $120.2(2)$ & C18_12 & C19_12 & C24_12 & $122.59(19)$ \\
\hline C9_9 & C10_9 & C11_9 & $121.5(2)$ & C20_12 & C19_12 & C24_12 & $119.5(2)$ \\
\hline C6_9 & C11_9 & C15_9 & $122.68(18)$ & C21_12 & C20_12 & C19_12 & $120.9(2)$ \\
\hline C10_9 & C11_9 & C6_9 & 117.41(19) & C20_12 & C21_12 & C22_12 & $120.3(2)$ \\
\hline C10_9 & C11_9 & C15_9 & $119.89(19)$ & C21_12 & C22_12 & C23_12 & $120.7(2)$ \\
\hline C7_9 & C12_9 & C13_9 & $112.0(2)$ & C18_12 & C23_12 & C27_12 & $122.3(2)$ \\
\hline C7_9 & C12_9 & C14_9 & $110.0(2)$ & C22_12 & C23_12 & C18_12 & $118.0(2)$ \\
\hline C14_9 & C12_9 & C13_9 & $110.7(2)$ & C22_12 & C23_12 & C27_12 & $119.6(2)$ \\
\hline C11_9 & C15_9 & C16_9 & $111.8(2)$ & C19_12 & C24_12 & C25_12 & $111.3(2)$ \\
\hline C11_9 & C15_9 & C17_9 & 111.1(2) & C19_12 & C24_12 & C26_12 & $111.8(2)$ \\
\hline C16_9 & C15_9 & C17_9 & $110.5(2)$ & C25_12 & C24_12 & C26_12 & $110.1(2)$ \\
\hline C19_9 & C18_9 & N2_9 & 119.15(18) & C23_12 & C27_12 & C28_12 & $110.7(2)$ \\
\hline C19_9 & C18_9 & C23_9 & $122.60(18)$ & C23_12 & C27_12 & C29_12 & $111.5(2)$ \\
\hline C23_9 & C18_9 & N2_9 & 117.98(18) & C28_12 & C27_12 & C29_12 & $110.7(2)$ \\
\hline C18_9 & C19_9 & C20_9 & 117.46(19) & C1_13 & N1_13 & C2_13 & $125.74(19)$ \\
\hline C18_9 & C19_9 & C24_9 & 123.16(19) & C1_13 & N1_13 & C6_13 & $118.13(18)$ \\
\hline C20_9 & C19_9 & C24_9 & 119.37(19) & C6_13 & N1_13 & C2_13 & $115.25(18)$ \\
\hline C21_9 & C20_9 & C19_9 & $120.9(2)$ & C1_13 & N2_13 & C5_13 & $129.43(18)$ \\
\hline C20_9 & C21_9 & C22_9 & $120.5(2)$ & C1_13 & N2_13 & C18_13 & $116.95(19)$ \\
\hline C21_9 & C22_9 & C23_9 & $120.8(2)$ & C18_13 & N2_13 & C5_13 & $113.41(18)$ \\
\hline C18_9 & C23_9 & C27_9 & 122.13(19) & N1_13 & C1_13 & $\mathrm{Cu} 5$ & $119.60(15)$ \\
\hline C22_9 & C23_9 & C18_9 & $117.75(19)$ & N1_13 & C1_13 & N2_13 & $117.66(19)$ \\
\hline C22_9 & C23_9 & C27_9 & 120.12(19) & N2_13 & C1_13 & $\mathrm{Cu} 5$ & $122.74(15)$ \\
\hline C19_9 & C24_9 & C25_9 & $111.6(2)$ & N1_13 & C2_13 & C3_13 & $113.7(2)$ \\
\hline C19_9 & C24_9 & C26_9 & $111.3(2)$ & C2_13 & C3_13 & C4_13 & $111.06(19)$ \\
\hline C25_9 & C24_9 & C26_9 & $109.8(2)$ & C5_13 & C4_13 & C3_13 & $112.5(2)$ \\
\hline C23_9 & C27_9 & C28_9 & $111.0(2)$ & N2_13 & C5_13 & C4_13 & $114.5(2)$ \\
\hline C23_9 & C27_9 & C29_9 & $112.2(2)$ & C7_13 & C6_13 & N1_13 & $118.56(18)$ \\
\hline C28_9 & C27_9 & C29_9 & $110.5(2)$ & C7_13 & C6_13 & C11_13 & $122.25(18)$ \\
\hline C1_10 & N1_10 & C2_10 & $124.89(18)$ & C11_13 & C6_13 & N1_13 & $119.04(19)$ \\
\hline C1_10 & N1_10 & C6_10 & 118.17(18) & C6_13 & C7_13 & C12_13 & $122.71(19)$ \\
\hline C6_10 & N1_10 & C2_10 & $115.20(18)$ & C8_13 & C7_13 & C6_13 & 117.91(19) \\
\hline C1_10 & N2_10 & C5_10 & $129.37(18)$ & C8_13 & C7_13 & C12_13 & $119.32(19)$ \\
\hline C1_10 & N2_10 & C18_10 & $117.29(18)$ & C9_13 & C8_13 & C7_13 & $120.6(2)$ \\
\hline C18_10 & N2_10 & C5_10 & $113.25(17)$ & C10_13 & C9_13 & C8_13 & $120.3(2)$ \\
\hline N1_10 & C1_10 & $\mathrm{Cu} 3$ & $117.79(14)$ & C9_13 & C10_13 & C11_13 & $121.3(2)$ \\
\hline N1_10 & C1_10 & N2_10 & 117.73(19) & C6_13 & C11_13 & C15_13 & $122.39(19)$ \\
\hline N2_10 & C1_10 & $\mathrm{Cu} 3$ & 124.01(16) & C10_13 & C11_13 & C6_13 & $117.59(19)$ \\
\hline N1_10 & C2_10 & C3_10 & $113.5(2)$ & C10_13 & C11_13 & C15_13 & 119.78(19) \\
\hline C2_10 & C3_10 & C4_10 & $110.90(19)$ & C7_13 & C12_13 & C13_13 & $112.0(2)$ \\
\hline C5_10 & C4_10 & C3_10 & $111.9(2)$ & C7_13 & C12_13 & C14_13 & $110.2(2)$ \\
\hline N2_10 & C5_10 & C4_10 & $114.32(19)$ & C14_13 & C12_13 & C13_13 & $110.6(2)$ \\
\hline C7_10 & C6_10 & N1_10 & 118.57(18) & C11_13 & C15_13 & C16_13 & $112.0(2)$ \\
\hline C7_10 & C6_10 & C11_10 & $121.98(18)$ & C11_13 & C15_13 & C17_13 & $110.7(2)$ \\
\hline C11_10 & C6_10 & N1_10 & $119.45(19)$ & C16_13 & C15_13 & C17_13 & $110.8(2)$ \\
\hline
\end{tabular}




\begin{tabular}{|c|c|c|c|c|c|c|c|}
\hline C6_10 & C7_10 & C12_10 & $122.36(19)$ & C19_13 & C18_13 & N2_13 & $119.38(19)$ \\
\hline C8_10 & C7_10 & C6_10 & $118.08(19)$ & C19_13 & C18_13 & C23_13 & $122.52(18)$ \\
\hline C8_10 & C7_10 & C12_10 & $119.5(2)$ & C23_13 & C18_13 & N2_13 & $118.03(19)$ \\
\hline C7_10 & C8_10 & C9_10 & $120.6(2)$ & C18_13 & C19_13 & C20_13 & $117.58(19)$ \\
\hline C10_10 & C9_10 & C8_10 & $120.1(2)$ & C18_13 & C19_13 & C24_13 & $123.23(19)$ \\
\hline C9_10 & C10_10 & C11_10 & $121.4(2)$ & C20_13 & C19_13 & C24_13 & $119.2(2)$ \\
\hline C6_10 & C11_10 & C15_10 & $122.91(19)$ & C21_13 & C20_13 & C19_13 & $120.7(2)$ \\
\hline C10_10 & C11_10 & C6_10 & $117.6(2)$ & C20_13 & C21_13 & C22_13 & $120.7(2)$ \\
\hline C10_10 & C11_10 & C15_10 & $119.51(19)$ & C21_13 & C22_13 & C23_13 & $120.5(2)$ \\
\hline C7_10 & C12_10 & C13_10 & $111.6(2)$ & C18_13 & C23_13 & C27_13 & $121.8(2)$ \\
\hline C7_10 & C12_10 & C14_10 & $110.3(2)$ & C22_13 & C23_13 & C18_13 & $117.9(2)$ \\
\hline C14_10 & C12_10 & C13_10 & $110.9(2)$ & C22_13 & C23_13 & C27_13 & $120.1(2)$ \\
\hline C11_10 & C15_10 & C16_10 & $111.7(2)$ & C19_13 & C24_13 & C25_13 & $111.6(2)$ \\
\hline C11_10 & C15_10 & C17_10 & $110.9(2)$ & C19_13 & C24_13 & C26_13 & $111.2(2)$ \\
\hline C16_10 & C15_10 & C17_10 & $110.4(2)$ & C25_13 & C24_13 & C26_13 & $109.9(2)$ \\
\hline C19_10 & C18_10 & N2_10 & $119.04(18)$ & C23_13 & C27_13 & C28_13 & $110.4(2)$ \\
\hline C19_10 & C18_10 & C23_10 & $122.36(18)$ & C23_13 & C27_13 & C29_13 & $112.3(2)$ \\
\hline C23_10 & C18_10 & N2_10 & $118.43(18)$ & C28_13 & C27_13 & C29_13 & $110.7(2)$ \\
\hline C18_10 & C19_10 & C20_10 & $117.69(19)$ & N1S_2 & C2S_2 & C3S_2 & $177.8(6)$ \\
\hline C18_10 & C19_10 & C24_10 & $122.91(19)$ & N1S_3 & C2S_3 & C3S_3 & $179.3(6)$ \\
\hline C20_10 & C19_10 & C24_10 & $119.39(19)$ & N1S_4 & C2S_4 & C3S_4 & $178.7(6)$ \\
\hline C21_10 & C20_10 & C19_10 & $120.8(2)$ & N1S_5 & C2S_5 & C3S_5 & $178.0(6)$ \\
\hline C20_10 & C21_10 & C22_10 & $120.5(2)$ & N1S_6 & C2S_6 & C3S_6 & $177.4(9)$ \\
\hline C21_10 & C22_10 & C23_10 & $120.7(2)$ & N1S_7 & C2S_7 & C3S_7 & $179.8(8)$ \\
\hline C18_10 & C23_10 & C27_10 & $122.36(19)$ & N1S_1 & C2S_1 & C3S_1 & 179.1(7) \\
\hline C22_10 & C23_10 & C18_10 & $118.00(19)$ & & & & \\
\hline
\end{tabular}




\section{Compound 4}

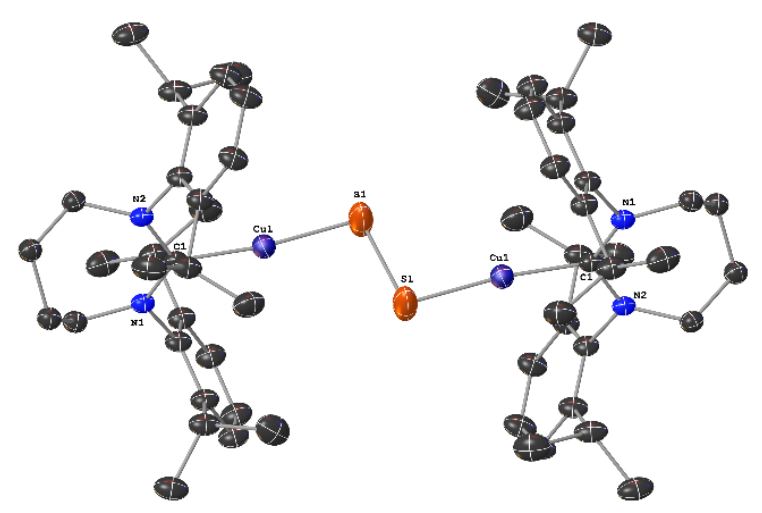

Experimental. Single yellow plate-shaped crystals of $\mathbf{4}$ were chosen from the sample. A suitable crystal $0.39 \times 0.28 \times 0.13 \mathrm{~mm}^{3}$ was selected and mounted on a loop with paratone oil on a Bruker D8 VENTURE diffractometer. The crystal was kept at $T=100(2) \mathrm{K}$ during data collection. The structure was solved with the ShelXT ${ }^{5}$ structure solution program using the Intrinsic Phasing solution method and by using Olex $2^{4}$ as the graphical interface. The model was refined with version 2018/3 of ShelXL ${ }^{7}$ using Least Squares minimization.

Crystal Data. $\mathrm{C}_{58} \mathrm{H}_{84} \mathrm{Cu}_{2} \mathrm{~N}_{4} \mathrm{~S}_{2}, M_{r}=1028.53$, monoclinic, $P 2_{1} / n$ (No. 14), a = 12.3238(9) $\AA, \mathrm{b}=$ 23.592(2) $\AA, \mathrm{c}=12.3896(11) \AA ̊ ., \beta=91.999(3)^{\circ}, \alpha=\gamma=90^{\circ}, V=3600.0(5) \AA^{3}, T=100(2) \mathrm{K}$, $Z=2, Z^{\prime}=0.5, \mu\left(\mathrm{MoK}_{\alpha}\right)=0.679 \mathrm{~mm}^{-1}, 62264$ reflections measured, 8228 unique $\left(R_{\text {int }}=\right.$ 0.0389 ) which were used in all calculations. The final $w R_{2}$ was 0.2052 (all data) and $R_{1}$ was $0.0649(\mathrm{I}>2 \sigma(\mathrm{I}))$. 
Table S4. Crystal Data for 1.

\begin{tabular}{|c|c|}
\hline Compound & 4 \\
\hline Formula & $\mathrm{C}_{58} \mathrm{H}_{84} \mathrm{Cu}_{2} \mathrm{~N}_{4} \mathrm{~S}_{2}$ \\
\hline$D_{\text {calc. }} / \mathrm{g} \mathrm{cm}^{-3}$ & 0.949 \\
\hline$\mu / \mathrm{mm}^{-1}$ & 0.679 \\
\hline Formula Weight & 1028.53 \\
\hline Colour & yellow \\
\hline Shape & plate \\
\hline Size $/ \mathrm{mm}^{3}$ & $0.39 \times 0.28 \times 0.13$ \\
\hline$T / \mathrm{K}$ & $100(2)$ \\
\hline Crystal System & monoclinic \\
\hline Space Group & $P 2_{1} / n$ \\
\hline$a / \AA$ & $12.3238(9)$ \\
\hline$b / \AA$ & $23.592(2)$ \\
\hline$c / \AA$ & $12.3896(11)$ \\
\hline$\alpha /^{\circ}$ & 90 \\
\hline$\beta /^{\circ}$ & $91.999(3)$ \\
\hline$\gamma /^{\circ}$ & 90 \\
\hline $\mathrm{V} / \AA^{3}$ & $3600.0(5)$ \\
\hline$Z$ & 2 \\
\hline$Z^{\prime}$ & 0.5 \\
\hline Wavelength/Å & 0.710730 \\
\hline Radiation type & $\operatorname{MoK}_{\alpha}$ \\
\hline$\Theta_{\min } /^{\circ}$ & 2.291 \\
\hline$\left.\Theta_{\max }\right|^{\circ}$ & 27.482 \\
\hline Measured Refl. & 62264 \\
\hline Independent Refl. & 8228 \\
\hline $\begin{array}{l}\text { Reflections with I > } \\
2(\text { I) }\end{array}$ & 7203 \\
\hline$R_{\text {int }}$ & 0.0389 \\
\hline Parameters & 322 \\
\hline Restraints & 302 \\
\hline Largest Peak & 1.183 \\
\hline Deepest Hole & -0.628 \\
\hline GooF & 1.036 \\
\hline$w R_{2}$ (all data) & 0.2052 \\
\hline$w R_{2}$ & 0.1992 \\
\hline$R_{1}$ (all data) & 0.0704 \\
\hline$R_{1}$ & 0.0649 \\
\hline
\end{tabular}

Table S5. Bond Length $(\AA)$ for 4

\begin{tabular}{|c|c|c|}
\hline Atom & Atom & Length/Å \\
\hline C2 & $\mathrm{C} 3$ & $1.401(3)$ \\
\hline $\mathrm{C} 2$ & C10 & $1.396(4)$ \\
\hline $\mathrm{C} 2$ & N1_1 & $1.456(3)$ \\
\hline C2 & N1_2 & $1.454(3)$ \\
\hline C3 & C4 & $1.509(4)$ \\
\hline C3 & $\mathrm{C} 7$ & $1.396(4)$ \\
\hline C4 & $\mathrm{C} 5$ & $1.527(4)$ \\
\hline C4 & C6 & $1.516(4)$ \\
\hline C7 & C8 & $1.385(4)$ \\
\hline C8 & C9 & $1.383(4)$ \\
\hline C9 & C10 & $1.407(4)$ \\
\hline C10 & C11 & $1.517(4)$ \\
\hline C11 & C12 & $1.523(4)$ \\
\hline C11 & C13 & $1.546(5)$ \\
\hline C18 & C19 & $1.409(3)$ \\
\hline C18 & $\mathrm{C} 26$ & $1.393(4)$ \\
\hline C18 & N2_1 & $1.454(3)$ \\
\hline C18 & N2_2 & $1.458(3)$ \\
\hline C19 & $\mathrm{C} 20$ & $1.521(4)$ \\
\hline C19 & $\mathrm{C} 23$ & $1.389(4)$ \\
\hline $\mathrm{C} 20$ & $\mathrm{C} 21$ & $1.525(4)$ \\
\hline $\mathrm{C} 20$ & $\mathrm{C} 22$ & $1.523(4)$ \\
\hline C23 & $\mathrm{C} 24$ & $1.384(4)$ \\
\hline C24 & $\mathrm{C} 25$ & $1.396(4)$ \\
\hline C25 & $\mathrm{C} 26$ & $1.393(4)$ \\
\hline C26 & $\mathrm{C} 27$ & $1.522(4)$ \\
\hline C27 & $\mathrm{C} 28$ & $1.529(4)$ \\
\hline C27 & $\mathrm{C} 29$ & $1.526(5)$ \\
\hline S1 & $\mathrm{S} 1^{1}$ & $2.119(2)$ \\
\hline S1 & Cu1_1 & $2.1315(10)$ \\
\hline S1 & $\mathrm{Cu} 1 \_2$ & $2.1315(10)$ \\
\hline Cu1_1 & C1_1 & $1.899(2)$ \\
\hline N1_1 & C1_1 & $1.345(3)$ \\
\hline N1_1 & C14_1 & $1.487(3)$ \\
\hline N2_1 & C1_1 & $1.357(3)$ \\
\hline N2_1 & C17_1 & $1.475(3)$ \\
\hline C14_1 & C15_1 & $1.501(4)$ \\
\hline C15_1 & C16_1 & $1.543(4)$ \\
\hline C16_1 & C17_1 & $1.507(4)$ \\
\hline Cu1_2 & C1_2 & $1.899(2)$ \\
\hline $\mathrm{N} 1 \_\overline{2}$ & C1_2 & $1.345(3)$ \\
\hline N1_2 & C14_2 & $1.487(3)$ \\
\hline N2_2 & C1_2 & $1.357(3)$ \\
\hline N2_2 & C17_2 & $1.475(3)$ \\
\hline C14_2 & C15_2 & $1.501(4)$ \\
\hline C15_2 & C16_2 & $1.543(4)$ \\
\hline C16_2 & C17_2 & $1.507(4)$ \\
\hline
\end{tabular}


Table S6. Bond Angle (deg) for 4

\begin{tabular}{|c|c|c|c|}
\hline Atom & Atom & Atom & Angle $/^{\circ}$ \\
\hline $\mathrm{C} 3$ & $\mathrm{C} 2$ & N1_1 & $122.6(3)$ \\
\hline C3 & $\mathrm{C} 2$ & N1_2 & 116.3(3) \\
\hline C10 & $\mathrm{C} 2$ & $\mathrm{C} 3$ & $122.0(2)$ \\
\hline C10 & $\mathrm{C} 2$ & N1_1 & $115.3(3)$ \\
\hline C10 & $\mathrm{C} 2$ & N1_2 & $121.6(3)$ \\
\hline C2 & C3 & $\mathrm{C} 4$ & $122.8(2)$ \\
\hline C7 & C3 & $\mathrm{C} 2$ & $117.9(2)$ \\
\hline C7 & C3 & $\mathrm{C} 4$ & 119.3(2) \\
\hline C3 & $\mathrm{C} 4$ & C5 & $110.5(2)$ \\
\hline C3 & C4 & C6 & 111.3(3) \\
\hline C6 & $\mathrm{C} 4$ & $\mathrm{C} 5$ & 112.1(3) \\
\hline C8 & C7 & C3 & $121.4(3)$ \\
\hline C9 & C8 & C7 & 119.8(3) \\
\hline C8 & C9 & $\mathrm{C} 10$ & $121.0(3)$ \\
\hline C2 & C10 & C9 & $117.9(2)$ \\
\hline $\mathrm{C} 2$ & C10 & C11 & $122.8(2)$ \\
\hline C9 & C10 & C11 & $119.3(2)$ \\
\hline C10 & C11 & C12 & $111.4(2)$ \\
\hline C10 & C11 & C13 & 111.1(3) \\
\hline C12 & C11 & C13 & 109.7(3) \\
\hline C19 & C18 & N2_1 & $114.5(3)$ \\
\hline C19 & C18 & N2_2 & $120.7(2)$ \\
\hline $\mathrm{C} 26$ & C18 & C19 & $122.0(2)$ \\
\hline $\mathrm{C} 26$ & C18 & N2_1 & $123.4(3)$ \\
\hline C26 & C18 & N2_2 & $117.3(2)$ \\
\hline C18 & C19 & $\mathrm{C} 20$ & $122.6(2)$ \\
\hline $\mathrm{C} 23$ & C19 & C18 & $117.7(2)$ \\
\hline C23 & C19 & $\mathrm{C} 20$ & $119.7(2)$ \\
\hline C19 & $\mathrm{C} 20$ & $\mathrm{C} 21$ & 111.1(3) \\
\hline C19 & $\mathrm{C} 20$ & $\mathrm{C} 22$ & $110.9(2)$ \\
\hline $\mathrm{C} 22$ & $\mathrm{C} 20$ & C21 & $111.0(3)$ \\
\hline C24 & $\mathrm{C} 23$ & C19 & $121.5(3)$ \\
\hline $\mathrm{C} 23$ & $\mathrm{C} 24$ & $\mathrm{C} 25$ & $119.8(3)$ \\
\hline C26 & $\mathrm{C} 25$ & $\mathrm{C} 24$ & $120.6(3)$ \\
\hline C18 & $\mathrm{C} 26$ & $\mathrm{C} 25$ & $118.4(2)$ \\
\hline
\end{tabular}

\begin{tabular}{|c|c|c|c|}
\hline Atom & Atom & Atom & Angle $/^{\circ}$ \\
\hline$\overline{\mathrm{C} 18}$ & $\mathrm{C} 26$ & C27 & $122.8(2)$ \\
\hline $\mathrm{C} 25$ & $\mathrm{C} 26$ & $\mathrm{C} 27$ & $118.8(2)$ \\
\hline C26 & $\mathrm{C} 27$ & $\mathrm{C} 28$ & $111.7(2)$ \\
\hline C26 & $\mathrm{C} 27$ & $\mathrm{C} 29$ & $111.2(3)$ \\
\hline C29 & $\mathrm{C} 27$ & $\mathrm{C} 28$ & 111.1(3) \\
\hline $\mathrm{S} 1^{1}$ & S1 & Cu1_1 & $99.66(6)$ \\
\hline $\mathrm{S} 1^{1}$ & S1 & Cu1_2 & $99.66(6)$ \\
\hline C1_1 & Cu1_1 & $\mathrm{S} 1$ & $171.87(12)$ \\
\hline $\mathrm{C} 2$ & N1_1 & C14_1 & $115.3(2)$ \\
\hline C1_1 & N1_1 & $\mathrm{C} 2$ & $115.6(2)$ \\
\hline C1_1 & N1_1 & C14_1 & $129.05(19)$ \\
\hline C18 & N2_1 & C17_1 & $115.1(2)$ \\
\hline C1_1 & N2_1 & C18 & $116.97(18)$ \\
\hline C1_1 & N2_1 & C17_1 & $127.70(19)$ \\
\hline N1_1 & C1_1 & Cu1_1 & $123.14(16)$ \\
\hline N1_1 & C1_1 & N2_1 & $117.8(2)$ \\
\hline N2_1 & C1_1 & Cu1_1 & $117.60(15)$ \\
\hline N1_1 & C14_1 & C15_1 & $113.67(19)$ \\
\hline C14_1 & C15_1 & C16_1 & $112.3(2)$ \\
\hline C17_1 & C16_1 & C15_1 & $111.9(2)$ \\
\hline N2_1 & C17_1 & C16_1 & $114.13(18)$ \\
\hline C1_2 & $\mathrm{Cu} 1 \_2$ & $\mathrm{~S} 1$ & $173.60(9)$ \\
\hline $\mathrm{C} 2$ & N1_2 & C14_2 & $113.21(19)$ \\
\hline C1_2 & N1_2 & $\mathrm{C} 2$ & $117.48(19)$ \\
\hline C1_2 & N1_2 & C14_2 & $129.07(19)$ \\
\hline C18 & N2_2 & C17_2 & $117.1(2)$ \\
\hline C1_2 & N2_2 & C18 & $114.91(19)$ \\
\hline C1_2 & N2_2 & C17_2 & $127.68(19)$ \\
\hline N1_2 & C1_2 & Cu1_2 & $123.15(16)$ \\
\hline N1_2 & C1_2 & N2_2 & $117.8(2)$ \\
\hline N2_2 & C1_2 & Cu1_2 & $117.60(15)$ \\
\hline N1_2 & C14_2 & C15_2 & $113.68(19)$ \\
\hline C14_2 & C15_2 & C16_2 & $112.3(2)$ \\
\hline C17_2 & C16_2 & C15_2 & $111.9(2)$ \\
\hline N2_2 & C17_2 & C16_2 & $114.12(18)$ \\
\hline
\end{tabular}




\section{References}

(1) Jordan, A. J.; Wyss, C. M.; Bacsa, J.; Sadighi, J. P. Synthesis and Reactivity of New Copper(I) Hydride Dimers. Organometallics 2016, 35, 613-616.

(2) Zhai, J.; Filatov, A. S.; Hillhouse, G. L.; Hopkins, M. D. Synthesis, structure, and reactions of a copper-sulfido cluster comprised of the parent $\mathrm{Cu} 2 \mathrm{~S}$ unit: $\{(\mathrm{NHC}) \mathrm{Cu}\} 2(\mu-\mathrm{S})$. Chem. Sci. 2016, 7, 589-595.

(3) Hartman, J. S.; Shoemaker, J. A. W.; Janzen, A. F.; Ragogna, P. J.; Szerminski, W. R. The coordination chemistry of (py) $2 \mathrm{BF}+2$ and related difluoroboron cations. J. Fluorine Chem. 2003, 119, 125-139.

(4) Dolomanov, O.V., Bourhis, L. J., Gildea, R. J, Howard, J. A. K. \& Puschmann, H. J. Appl. Cryst. 2009, 42, 339-341.

(5) Sheldrick, G.M. Acta Cryst. 2015 A71, 3-8.

(6) Sheldrick, G.M. Acta Cryst. 2015 C71, 3-8.

(7) Sheldrick, G.M. Acta Cryst. 2015 C27, 3-8. 